Alexandre Farias Watanabe

\title{
A EXPERIÊNCIA DAS RAÍZES E O DEKASSEGUI \\ UM ESTUDO DE PSICOLOGIA SOCIAL A PARTIR DE RECONSTRUÇ̃̃o \\ AUTOBIOGRÁFICA
}

Dissertação apresentada ao Instituto de Psicologia da Universidade de São Paulo como parte dos requisitos para a obtenção do título de Mestre em Psicologia

São Paulo

2008 
Alexandre Farias Watanabe

\section{A EXPERIÊNCIA DAS RAÍZES E O DEKASSEGUI UM ESTUDO DE PSICOLOGIA SOCIAL A PARTIR DE RECONSTRUÇÃO AUTOBIOGRÁFICA}

Dissertação apresentada ao Instituto de Psicologia da Universidade de São Paulo como parte dos requisitos para a obtenção do título de Mestre em Psicologia

Área de concentração: Psicologia Social

Orientador: Prof. Dr. José Moura Gonçalves Filho

\section{São Paulo}

2008 
AUTORIZO A REPRODUÇÃO E DIVULGAÇÃO TOTAL OU PARCIAL DESTE TRABALHO, POR QUALQUER MEIO CONVENCIONAL OU ELETRÔNICO, PARA FINS DE ESTUDO E PESQUISA, DESDE QUE CITADA A FONTE.

Catalogação na publicação Serviço de Biblioteca e Documentação Instituto de Psicologia da Universidade de São Paulo

Watanabe, Alexandre Farias.

A experiência das raízes e o dekassegui: um estudo de psicologia social a partir de reconstrução autobiográfica / Alexandre Farias Watanabe; orientador José Moura Gonçalves Filho. -- São Paulo, 2008.

$113 \mathrm{p}$.

Dissertação (Mestrado - Programa de Pós-Graduação em Psicologia. Área de Concentração: Psicologia Social) - Instituto de Psicologia da Universidade de São Paulo.

1. Imigração 2. Memória 3. Trabalho 4. Identidade 5. Desenraizamento social I. Título.

GN370 


\section{A EXPERIÊNCIA DAS RAÍZES E O DEKASSEGUI}

UM ESTUDO DE PSIOCLOGIA SOCIAL A PARTIR DE RECONSTRUÇÃO AUTOBIOGRÁFICA

\section{Alexandre Farias Watanabe}

\section{BANCA EXAMINADORA}

(nome e assinatura)

(nome e assinatura)

(nome e assinatura)

Dissertação defendida e aprovada em 
"Não siga os antigos procure o que eles procuraram" (Matsuo Basho) 
A meus pais, Shim Watanabe (in memorian) e Maria de Lurdes Farias;

à minha vó Santa Rocha (in memorian), pelas alegrias vespertinas,

ao Kenzo, Ikematsu e Kondo-san e àqueles que me acolheram nas fábricas nipônicas;

aos meus sobrinhos Vinícius, Giulia e Bianca, com esperança. 


\section{Agradeço}

aos professores Gilbero Safra, Ecléa Bosi e Francisco Hashimoto, pelo apoio e pela leitura sensível e generosa que fizeram, acompanhando o desenvolvimento deste trabalho ainda lacunar. Espero poder retribuir, a partir de agora, as muitas e preciosas lições, partilhando com outros o que com vocês aprendi e ainda sigo aprendendo;

à professora Leny Sato e aos amigos Fábio de Oliveira, Cris, Tati, Allan, Bernardo e Audrey pelo convite para ir ao Cpat, no início de 2001, falar de minha experiência japonesa. Grato: sua escuta atenciosa naquela manhã foi o início desta pesquisa;

aos colegas e amigos da Verso Cooperativa, a quem ainda faltou dizer: se não estamos mais juntos, é também porque o mundo escravizado pelos valores mercantis ainda se fecha à nossa persistência em acolher, acima de tudo, os tempos e modos do existir de cada um. Muito obrigado a todos vocês;

à minha família, em especial meus irmãos Ana, Giancarlo e Cláudio: por seus exemplos, vocês fizeram o irmãozinho caçula querer crescer e fazer grandes coisas no mundo, pelo mundo. Cláudio pelo "HAL 9000" (que aguentou bravamente!), Ana pelo resumo em inglês, Gian pelas aulas de kung fu. À madrinha Marise por sempre ter tido fé em mim e em minhas escolhas. A meus tios Glória, Severino, Elza e Chico, por terem olhado por mim A meus primos pela amizade e bom humor da infância vivos até hoje;

aos amigos Gabi e Daniel, por me apresentarem João Antônio e mais outras boas literaturas. Gabi pelo doce, Daniel pelo amargo, me mostraram que há sempre muito para saborear na vida;

ao Fabinho Madureira, André Scarlati, "Alfredo" Michaelis e Luiz Mena, meus irmãos de escolha, por boa música, futebol, filosofia, risos (lá e aqui) e viagens pelo Brasil (Hey-ho, let's go!);

aos amigos Fernando Braga, Roberta Boaretto, Thais, Biancha, Vivi, Fernanda, Carlito, Pauli, Flavinha, Ourinhos, Claudinha, Alice, Anaruez, Montanha, Roger. Hoje próximos ou distantes, estavam comigo naquele início cheio de esperança;

ao Jackson, Sueli Tiemi, Bá, Ricardo, Raimundo, Emerson, Lica, Môgi, Joe, Valmir, Márcio, Mochizuki, Ishikawa, Suzuki e Sano-san. É também de vocês este trabalho;

a Fábio Ocada, pelo envio de seu belíssimo trabalho, importante para corrigir certas imprecisões deste;

a Allan Safiotti, pela ajuda vital de última hora; 
à Nalva e à Cecília, pela assistência fundamental nesse longo percurso na pósgraduação;

a Tamaki sensei, por me introduzir ao kendo e ao iaido, aprendendo também. Domo arigato, sensei;

ao Zeca que, me convidando a habitar o concreto, e habitando-o comigo, me fez aparecer como autor. $\mathrm{O}$ orientador virou um amigo, um guia e um exemplo. Sua companhia generosa ao longo desses anos foi também uma espécie de "casa da aliança" onde pude existir e crescer. Obrigado, muito obrigado.

à Adrienne, meu amor, alegria minha. 


\section{SUMÁRIO}

Introdução

Objetivos e Metodologia

Reconstrução autobiográfica

Considerações finais

Referências bibliográficas

Anexos p.12

p. 26

p. 32

p. 100

p. 102

p. 103 
Watanabe, Alexandre Farias $A$ experiência das raizes e o dekassegui: um estudo de Psicologia Social a partir de reconstrução autobiográfica. São Paulo, 2008. 113 p. Dissertação (Mestrado). Instituto de Psicologia, Universidade de São Paulo.

\section{RESUMO}

O termo dekassegui aponta a condição do trabalhador estrangeiro e nipo-descendente na indústria japonesa. Pressionado por perspectivas adversas de emprego no Brasil e estimulado pela legislação no país de destino, aceita submeter-se a trabalhos não-qualificados, atraído pelo valor de câmbio da moeda japonesa e com planos de retorno vantajoso após alguns anos.

Esta pesquisa pretende um estudo qualitativo de Psicologia Social atento aos temas antagonistas do enraizamento e do desenraizamento, duas noções advindas da experiência e obra de Simone Weil e Ecléa Bosi. Nossas hipóteses formaram-se em torno de duas suposições principais:

1) A condição dekassegui, em grande medida, instaura desenraizamento a) por quase deter o indivíduo no regime alienante e absorvente do trabalho subalterno e simples, impedindo ou empobrecendo a participação do nipo-descendente e sua nova experiência de cidade; b) por acompanhar uma inesperada resistência e até hostilidade dos japoneses contra os nipo-descendentes.

2) A possibilidade da condição dekassegui, ainda assim, apoiar e satisfazer o anseio por uma experiência do Japão e da cultura japonesa, é dependente da qualidade dos motivos que carregaram o nipo-descendente. Há motivos que não parecem bastar para tanto: motivos sobretudo econômicos ou motivos demais ideológicos (estes associados à construção de figuras sublimes ou soberbas do Japão e dos japoneses). Todavia, outra motivação parece estar por trás de alguns dekasseguis: incluindo e superando motivos econômicos e ideológicos, o anseio por conquistar, beneficiando-se da ida ao Japão, uma raiz, uma orientação psicossocial e cultural a respeito de si próprios; o anseio por consolidar o que podemos designar como uma "identidade de trânsito ou de troca" em lugar de uma identidade dilemática e dividida (a angustiante identidade do estrangeiro permanente, japonês no Brasil e brasileiro no Japão).

Por meio de reconstrução autobiográfica (o próprio pesquisador viveu oito meses a condição dekassegui), pretendemos identificar e discutir temas que representem marcos fortes (muito significativos ou muito enigmáticos) da experiência dekassegui, de maneira a confirmarmos ou infirmarmos as hipóteses acima.

Palavras-chave: dekassegui; memória; trabalho; identidade; imigração; desenraizamento social. 
Watanabe, Alexandre Farias. The root experience and the dekassegui: a Social Psycology from an auto-biographic reconstruction. São Paulo, 2008. 113 pp. M. Dissertation. Institute of Psychology, University of São Paulo.

\begin{abstract}
The therminology dekassegui refers to the foreign worker and the japanese descendant at the japanese industry. Driven by bad working perspectives in Brazil and estimulated by the legislation at country of destination, he accepts unqualified works, atracted by the japanese currency exchange and with plans of profitable return after a few years.

This research intends to do a qualitative study of Social Psychology about the antagonists themes of rooting and unrooting, two notions born from the experience and work of Simone Weil and Ecléa Bosi. Our hypothesis were based on two main assumptions:

1) The dekassegui condition, mostly, implements unrooting, a) by keeping the person on an absorving regimen of simple and unqualified work, preventing the participation of the japanese descendant and his new experience in town; b) by follow an unexpected resistance and even hostility from the japaneses against the nipo-descendents.

2) The possibility of the dekassegui to support and satisfy the anxious of a japanase experience, depends on the quality of the reasons that driven the japanese descendant. There are reasons which do not seem to be enough: mainly economical and execessives ideological reasons (these ones associated to the construction of superb and gorgeous figures about Japan and the japaneses. Although another motivation seems to be behind some dekasseguis: including and overcoming economic and ideological reasons, the anxious for conquering, getting benefit from the trip to Japan, a root, a pshyco-social and cultural orientation regarding themselves; the anxious to consolidate what we can call as a "changeable or temporary identity" instead of a divided and dilemmatic identity (the miserable identity of the permanent foreigner, japanese in Brazil and brazilian in Japan).

Through an autobiographic reconstruction (the researcher himself lived eight months on a dekassegui condition), we intend to identify and discuss themes which represent strong marks (very significant or very enigmatic) of the dekassegui experience, in order to confirm above hypothesis.
\end{abstract}

Key-words: dekassegui; memory; work; identity; migration; social unrooting. 


\section{INTRODUÇÃO}

A migração assumiu um novo caráter no último século. O capitalismo chegou a um novo momento de sua história, baseado sobretudo no desenvolvimento da ciência e da tecnologia aplicadas às relações econômicas. $\mathrm{O}$ desenvolvimento da informática e dos transportes possibilitou a integração de ações e espaços internacionais. Em escala global, articulou-se um sistema de produção, distribuição e consumo de bens, um mercado mundial com grande circulação de produtos, insumos, equipamentos, tecnologias e dinheiro, este último principalmente na forma de circulação financeira instantânea por transferências eletrônicas. Criou-se entre os países laços de complementaridade e integração entre processos produtivos, mercados consumidores e de trabalho, com difusão de parâmetros similares de organização social capitalista. Está em processo uma grande reestruturação das relações econômicas, políticas, sociais e culturais.

Nos países periféricos, aqueles fora do núcleo das nações que disparam e controlam este conjunto de ações, a globalização econômica acelerou, no entanto, processos de exclusão, resultando na queda da renda per capita, elevado nível de desemprego, precarização das condições de vida das populações mais pobres, queda do padrão de consumo das classes médias. Este quadro, somado à necessidade do uso de mão-de-obra barata nos países do núcleo hegemônico, desde o início visto como vantajoso por comportar menor investimento em tecnologia e menores salários, gerou o fenômeno da imigração internacional de trabalhadores. Grande número de pessoas assumiu, clandestinamente ou não, a função de força de trabalho na indústria, isso variando em função das políticas de incentivo ou regulação da migração adotadas nos países de destino. Mão-de-obra intercambiável, disponível para deslocamentos de país para país segundo a demanda da produção e fácil de adaptar à natureza das tarefas

exigidas (muito simples ou obedientes a padrões produtivos difundidos por todo o mundo), contratos temporários e/ou terceirizados que desoneram e desresponsabilizam o empregador. O caso japonês é, a esse respeito, exemplar.

A grande expansão industrial do Japão, a partir dos anos sessenta, fez-se da proliferação das pequenas e médias empresas subcontratadas pelas grandes indústrias, que passaram a descentralizar atividades onerosas e problemáticas, diminuindo a 
necessidade de filiais ou de expansão física, custos com mão-de-obra, estoques e espaços. As pequenas e médias cresceram a reboque da elevada demanda das grandes, sobretudo no auge econômico dos anos oitenta, mas um crescimento que ocorreu com pouco investimento em tecnologia, por razões de custo-benefício e/ou porque a natureza da atividade exigia a presença humana.

Se nos anos setenta a demanda por mão-de-obra foi suprida com o emprego dos próprios japoneses em jornadas de meio período ou temporárias, a partir dos oitenta foi necessário o emprego de estrangeiros, no início principalmente os da zona de influência geográfica próxima: coreanos, chineses e filipinos, contratados em sua maioria em situação ilegal de permanência no país. No auge dos anos oitenta, todavia, a reestruturação técnica da organização do trabalho e da produção, a insuficiente incorporação de mulheres ao mercado de trabalho, a diminuição da população juvenil ou a preferência dos jovens pelas grandes empresas (onde poderiam aspirar laços vitalícios com um grupo empresarial de prestígio), tornaram ainda mais agudo o problema da mãode-obra para as pequenas e médias empresas, que já arcavam com os custos das sanções governamentais por se utilizarem de mão-de-obra ilegal. Sem alternativa, e sob o risco extremo da falência dessa base econômica industrial, iniciou-se a política japonesa de migração seletiva, em 1990.

No início, eram admitidos os cônjuges estrangeiros dos japoneses emigrados (que, por isso, retornavam). Logo depois das reformas legais de junho de 1990, a lei de imigração autorizou o trabalho dos descendentes de primeira e segunda geração (os nissei e sansei), em grande maioria brasileiros (com uma parcela bem menor de peruanos, bolivianos e colombianos).

A abertura do Japão aos trabalhadores forâneos coincidiu com a desaceleração das economias internas latino-americanas e a conseqüente deterioração das condições de vida de suas populações na década de oitenta. O desemprego e o aprofundamento da crise forçaram as classes médias (onde se encontrava a maioria da população nipo-brasileira) a buscar saídas individuais para a queda de seu nível econômico e de suas perspectivas profissionais. Aceitaram, assim, tornar-se mão-de-obra para o trabalho qualificado pela população japonesa como "dos três k: kiken, kitanai e kitsui”, ou seja, perigoso, sujo e pesado - o trabalho oferecido pelas empresas pequenas e médias, principalmente nos 
setores eletrônico e automobilístico. A remuneração tida como alta para nossos padrões, a grande diferença de câmbio entre as moedas e a facilidade legal de entrada no Japão funcionaram como atrativo para aqueles que buscavam alternativas de sobrevivência ou melhoria em suas condições de vida, com planos de retorno ao Brasil após alguns anos. Iniciou-se, então, o grande fluxo migratório da população nipo-brasileira que ficou conhecida em terras japonesas como dekassegui ${ }^{1}$.

Sem tradução precisa para o português, dekassegui vem do japonês deru (sair) e kasegu (ganhar dinheiro) é em geral entendido como "aquele que busca trabalho temporário em outros lugares apenas para ganhar dinheiro". Antes associado às populações indígenas autóctones das ilhas do norte japonês que, no Japão medieval, migravam no inverno para as regiões mais ao sul em busca de trabalho, manteve-se como o apelido pejorativo para os nikkey recém-chegados para realizar, em sua permanência na indústria japonesa, os trabalhos "perigosos, sujos e pesados".

É nessa condição de trabalhador desqualificado, dispensado de qualquer mínimo conhecimento da língua japonesa, que lá chega o trabalhador nipo-descendente, admitido no país para realizar tarefas aviltantes desprezadas pela população local. Sua entrada se dá pela inserção nos meios das classes pobres japonesas, para realizar trabalhos marginais àqueles das indústrias tecnologicamente de ponta pelas quais o Japão destacou-se na economia mundial (Honda, Mitsubishi, Toyota, Sony, ...). Pouco importam aí os diferentes perfis individuais dos nikkey, entre si muito diferenciados: segundo a origem (rural ou urbana), escolaridade (muitos cursaram boas universidades), faixa etária, familiaridade com a língua e a cultura japonesas.

A vivência na terra dos ancestrais é marcada por dificuldades, tanto no ambiente de fábrica quanto nas atividades cotidianas, em contato com os japoneses. Os três "k", entre os brasileiros, ganharam outros dois: kibishii e kirai, severo e desgostoso, palavras que significativamente acrescentam características psicológicas às condições objetivas denotadas pelas outras três.

1 Sobre aspectos sociológicos do fenômeno dekassegui, ver: Kawamura, L. Para onde vão os brasileiros? Imigrantes brasileiros no Japão. Campinas, SP: EdUnicamp, 1999. 
Nos oito meses em que vivi como operário na indústria japonesa, os cinco " $\mathrm{k}$ " apresentaram-se com grande freqüência através de exemplos vividos, testemunhados ou que me foram narrados. O trabalho é perigoso, já que a máquina parece nunca incorporar dispositivos de segurança até que acidentes graves ocorram: assim foi com uma prensa só modificada após esmagar e mutilar a mão de um antigo funcionário japonês, colega de setor, poucos dias antes de meu retorno ao Brasil; ou no caso dos sensores óticos de uma máquina de dobra em que trabalhei e que oportunamente a desligavam quando havia algo interceptando o curso dos pesados corpos de aço que dobravam as peças, sensores só incorporados à máquina após ter sido imprudentemente usada por longos anos. E perigosas são também aquelas tarefas onde não há instruções de segurança e cujo risco é patente: o funcionário de quem ocupei o lugar na tarefa de carregar e empilhar caixas, em meu primeiro mês de trabalho, havia quebrado uma costela nalgum momento de desatenção, exaustão ou falta do "jeito" para levantamento do material pesado, lição que todos devíamos aprender sem guias no dia a dia do trabalho. A máquina com que trabalhei por mais tempo, em meu segundo emprego, todos os dias "mordia" meus dedos, pois era impossível encaixar as peças e mantê-las em seu suporte, onde eram fixadas por presilhas pneumáticas, sem correr o risco de levar ao menos beliscões nas mãos. Ainda que a prática me tivesse tornado mais hábil em evitar isso, o desenho da máquina me obrigava a pôr a ponta de algum dedo sobre o topo da peça para que ela não "saltasse" de sua posição ao impacto da presilha e assim terminasse, ao final da usinagem, fora de medida. Dado o formato das peças, pequenos "cachimbos" de cobre, a única parte por onde fixá-los não tinha mais que dois ou três milímetros: era a esta distância que se estava, portanto, dos acidentes. Além disso, era impossível que não acontecesse algo, naquela luta (sempre perdida) por manter a atenção diante dos mesmos poucos seis ou sete gestos simples, repetidos quase oito mil vezes por dia.

O trabalho é sujo. A graxa esverdeada que se fixava nos dedos, sob as unhas, era difícil de sair: no dia seguinte, ainda lá nas mãos, foi tornando-se a característica física de quem trabalhava ali. A fuligem, o pó, o mal cheiro, os materiais manipulados que se impregnavam no corpo eram queixas comuns nas conversas.

E o trabalho é pesado, característica comum a todas as tarefas reservadas aos estrangeiros, homens e mulheres: longas horas carregando peso, movimentando e 
manipulando peças pesadas, executando movimentos em posições incômodas sem descanso, tudo resultava invariavelmente em exaustão no final do dia.

O trabalho é experimentado como uma tarefa orientada por extrema disciplina, por exigências de cadência e produtividade muito altas, cujos sentido e inteligibilidade escapam àquele que o faz, obedecendo regras que não podem ser objeto de discussão ou adaptação e sem serem temperadas por interação humana e alguma camaradagem entre trabalhadores ou entre trabalhadores e chefes. A cronometragem do tempo de execução das peças era parte da rotina, também as broncas constantes exigindo mais rapidez, atenção e método; a rigidez hierárquica, a obediência estrita - tudo isso: kibishii: severo, rígido.

Um trabalho assim organizado - disciplinado, repetitivo, impessoal, ofensivo ao corpo, à inteligência e à alma de quem trabalha, pelos ditames da própria máquina e pelo acolhimento precário de cada um no ambiente da fábrica - a pouca empatia, a desconfiança, a insignificante importância que se experimenta ter aos olhos do chefe, a falta de comunicação que permitisse o entendimento mútuo em relação às diferentes heranças culturais e suas formas de expressão - acabou qualificado pelos brasileiros como kirai: desgostoso, detestável.

As dificuldades continuam no contato cotidiano com os japoneses, para além do ambiente da fábrica. É aqui especialmente que a barreira da língua parece querer mostrarse com toda sua força, uma vez que no trabalho a natureza das tarefas, executadas em silêncio e solitariamente, não impõe a necessidade de interação entre nós, pois o que se diz é pouco, rápido e funcional, geralmente nas formas do comando e do assentimento. Costuma-se aprender apenas palavras relacionadas diretamente com o trabalho, que acabam misturadas ao português nas conversas entre dekasseguis brasileiros: "Ontem fiz quatro horas de zangyoo" (lê-se "zanguiô", hora-extra), ou "Não fiz nenhum furyoo na minha máquina hoje!" (“furiô", peça defeituosa, "matada”), "Quebrou o doriru!” (broca), e assim por diante. Fora dali, no entanto, onde a vida do migrante segue seu curso, um novo mundo se apresenta: os supermercados, as agências do correio, os bancos, os espaços de lazer e de circulação, tudo isso assusta, mostra-se desafiadoramente opaco, fechado, propondo situações a serem duramente decifradas, assimiladas, entendidas quase sempre só parcialmente. 
É comum em mercados e lojas japonesas a presença de funcionários na porta do estabelecimento recepcionando os clientes com um educado e sorridente "Irashaimase" ("Seja bem vindo", em japonês). Contudo é também muito freqüente que, percebida a entrada de um cliente brasileiro, este seja mais ou menos discretamente seguido em todo seu percurso entre as gôndolas, suspeito de algum eventual furto a ser flagrado. Duplo constrangimento, pois isso se soma ao fato de que o conteúdo do que está exposto nas gôndolas é muitas vezes indecifrável, sendo muito comum compras equivocadas (vi gente levando comida de gato por comida humana) ou repetição diária dos mesmos cardápios nos jantares dos recém-chegados, pois não se fica à vontade para pedir ajuda a algum daqueles funcionários.

Os telefones também são indecifráveis ao novato, que invariavelmente precisa da ajuda de alguém na hora de completar uma ligação para casa. Numa agência dos correios tudo está grafado em kanji (grafia com ideogramas) e outra vez dependemos de funcionários com quem não conseguimos conversar.

É difícil servir-se de ônibus, comprar bilhetes e circular de trem ou mesmo andar pelas ruas (que não têm seus nomes indicados em placas de esquina, como no Brasil). Simplesmente decoram-se itinerários e seqüências de ações eficientes: pelo medo de perder-se, pela impossibilidade de comunicar-se.

As distâncias são claras entre brasileiros e japoneses. A língua e a cultura tornamse barreiras difíceis de superar - entre nós e eles há entendimentos tácitos de situações que são às vezes opostos, sem acordo quanto aos sentimentos cabíveis, o repertório de gestos oportunos e o que esperarmos uns dos outros: o brasileiro olha no olho, o que pode ser ofensivo ao japonês; nosso alto tom de voz também lhes parece excessivo ou desrespeitoso; até nosso jeito de sentar, mais relaxado e "espalhado", conota má educação. E os exemplos se multiplicariam. $\mathrm{O}$ fato de sermos descendentes de japoneses faz parecer-lhes razoável esperar ou cobrar nosso entendimento da língua ou o respeito a certos costumes que somente um nativo pode conhecer. Os dekasseguis, aos olhos de muitos, estão no Japão apenas e tão somente por dinheiro, o que geralmente os japoneses julgam triste e condenável: a falta de mais largo compromisso com o trabalho chama o desprezo público. Quando acontece do dekassegui comparecer ao Japão por motivos que superam o motivo estritamente econômico, ainda assim acontecerá de lhe ser aplicada a 
figura de um agente interesseiro. Isso quer dizer que, no campo das barreiras lingüísticoculturais, soma-se ainda essa barreira ideológica.

A situação econômica de um dekassegui sofre facilmente um juízo moral arbitrário. Por mais que sejamos descendentes, potencialmente afeitos aos mesmos costumes, somos fundamentalmente vistos como estrangeiros (gaijin) de quem não se pode esperar boa conduta, pessoas sem compromisso com o país e seus valores, como, por exemplo, os de lealdade e dedicação à comunidade (e, por extensão, à empresa, vista como uma espécie de segundo lar japonês). Nossa mobilidade de um emprego a outro parece soar como uma traição, não como injunção. Nossa posição subalterna parece reforçada a cada encontro com alguns moradores que, por exemplo, não nos cumprimentam pela manhã ao sairmos para o trabalho, mas o fazem gentilmente com seus conterrâneos, deixando claro que nós somos passageiros e que o "Japão é para os japoneses", conforme me foi dito pelo colega de alojamento que testemunhava a cena comigo. A imagem do dekassegui parece congelar-se em lugares-comuns. Uns e outros aparecem de forma prejudicada, colada à sua máscara social. As relações com os espaços e com os outros permanecem fraturadas e tudo permanece estranho para o brasileiro: o que pareceria familiar fica indecifrável, frustrado em seu entendimento por falta de comunicação. Quantas vezes queremos nos portar do melhor modo, mas não sabemos como? Quantas vezes nos flagramos encantados com o que vemos, reconhecendo algo que nos parece próximo naqueles ambientes e naquela gente, querendo mesmo compreender mais e mais, conversar, ouvir explicações, histórias, narrativas sobre a vida de algum personagem? Ficamos ali dolorosamente divididos entre o muito familiar (a atmosfera das coisas, gestos, modos de ser que amamos desde a infância, gravado nas lembranças e recordações mais remotas) e o muito estrangeiro.

"O enraizamento", escreve Simone Weil, "é talvez a necessidade mais importante e menos conhecida da alma humana. É uma das mais difíceis de definir. O ser humano tem uma raiz por sua participação real, ativa e natural na existência de uma coletividade que conserva vivos certos tesouros do passado e certos pressentimentos do futuro. Participação natural, isto é, que vem automaticamente do lugar, do nascimento, da profissão, do ambiente. Cada ser humano precisa ter múltiplas raízes. Precisa receber quase que a totalidade de sua vida moral, intelectual, espiritual, por intermédio dos meios 
de que faz parte naturalmente."

Assim, ali onde foram prejudicados nossos laços de participação e os vínculos com o passado encontramos desenraizamento. Valemo-nos do que escreveu Ecléa Bosi: "Quando duas culturas se defrontam, não como predador e presa, mas como diferentes formas de existir, uma é para outra como uma revelação. Mas esta experiência raramente acontece fora dos pólos submissão-domínio. A cultura dominada perde os meios materiais de expressar sua originalidade". Aos brasileiros não foi aberta a oportunidade de inserção livre na sociedade japonesa, sendo claramente definida qual nossa porta de entrada e função social: a porta dos fundos, o trabalho não-qualificado, o período de permanência limitado, nenhuma perspectiva consistente de participação econômica e política. A admissão de nipo-descendentes não foi, conforme o imaginário criado pelo governo japonês entre seus cidadãos, um "retorno dos semelhantes". Não representou um acolhimento hospitaleiro daqueles que um dia emigraram e que hoje retornam com seus filhos e filhas, transformados pelo encontro com outros modos de ser. Se a chegada dos nipo-descendentes ao Japão atendeu àquilo que, como nos ensina Simone Weil, é complementar à necessidade de raízes - a necessidade de trocar influências - isso só ocorreu como um subproduto inesperado desse encontro que se deu motivado, principalmente (e dos dois lados) pela economia, não pela memória ou pelo desejo.

$\mathrm{Na}$ condição de subempregado é que chega o imigrante brasileiro: o trabalho subalterno e simples dispensa familiaridade com a língua da comunidade e dispensa qualificação para a execução das tarefas. O trabalho subalterno e simples, no Japão como em toda parte, não requer a experiência, o estilo, a inteligência e a criatividade do dekassegui; não respeita ou não admite seus ritmos e limites físicos, sua palavra ou opiniões no grupo que se organiza para as operações. Seu desejo de reconhecimento e cidadania fica interceptado; o sentido do que vê, obscurecido. O trabalho, onde poderia o trabalhador deixar a marca de sua singularidade, é mera repetição infinita de poucos movimentos, marca de pequenos ferimentos inúteis de que não se pode reclamar porque, já nos ensinava Simone Weil, a queixa resultaria numa humilhação ou punição, nunca em qualquer mudança quanto à forma da máquina, seu uso e mecanismo ou quanto ao nosso modo de trabalhar. O tédio, o tempo monótono da produção que embota o corpo e a alma, escravos da pura necessidade de subsistir. A impessoalidade dos chefes caprichosos, cuja 
autoridade deita-se no poder de nos pôr desempregados quando quiserem. "O desenraizamento por excelência é a ignorância do trabalhador em relação ao destino das coisas que fabrica. Qual seu valor e utilidade social? A que necessidades humanas ele atende? O que os outros homens devem agradecer-lhe?"2

Em alguma medida, temos de nos desvencilhar da condição dekassegui se desejarmos alcançar o Japão sob a crosta pesada que o torna semelhante a qualquer outro ambiente fabril e alienado. O trabalho dekassegui é atividade que nos dirige a vida sem nos permitir experimentá-la: comanda nosso tempo, mecaniza nossos gestos, estreita nossa atenção. Tornou-se controle de que temos que escapar se quisermos ainda insistir no desejo de olhar a cultura japonesa realizando-se em seu curso cotidiano, no corpo de suas gentes; se queremos deitar o olhos no mundo sem interesse e sem pressa, se queremos com paciência reparar, notar diferenças revelando-se.

Diríamos paradoxalmente e de bom grado que o trabalho, assim mesmo organizado, afinal não impede completamente as experiências qualitativas. Mas não é estranho esse impedimento presente na experiência de todos? Não deveria ser o trabalho o lugar privilegiado - e não apenas ocasional - para um encontro de um visitanteantropólogo com as profundas raízes de uma cultura, suas manifestações? Que diferenças guardaria, por exemplo, a experiência de trabalho de um estrangeiro aceito como discípulo de algum mestre-artesão da metalurgia de espadas samurai (mestrestrabalhadores cuja excelência é celebrada com o título de "Tesouros Nacionais Vivos", e inúmeros trabalhadores de diferentes áreas são assim chamados) e a desse mesmo estrangeiro (conheci brasileiros que trabalhavam assim) admitido numa linha de montagem de uma indústria automobilística, arrastando-se por horas a fio, madrugadas adentro, de gatinhas, sob uma linha de chacis onde deve fazer repetida e rapidamente quatro ou cinco pontos de solda? Não fossem as condições de sua organização, prevaleceriam os estigmas ligados a este trabalho e àqueles que nele se engajam (o "imigrante interesseiro" que atrai o desprezo dos colegas japoneses, a vigia nos mercados, etc), marca obscura que todo brasileiro experimenta ter pelos olhos de seus anfitriões? O desenraizamento começa quando predominam ostensivamente sobre as relações humanas suas qualidades econômicas e sobre o produto de seu trabalho as qualidades mercantis,

2 Bosi, Ecléa. O tempo vivo da memória. São Paulo: Ateliê Editorial, 2003. 
cada indivíduo contando apenas por sua capacidade maior ou menor de produzir valores de troca, por seu lugar hierárquico nessa cadeia abstrata.

Não fosse assim, existiriam afinal dekasseguis?

A motivação econômica dos nipo-descendentes, porém, pode esconder entre alguns deles outras motivações abertas pela aventura dekassegui.

A condição de "nipo-brasileiros" impõe uma identidade dividida: no Brasil, somos "japoneses"; no Japão, como dekasseguis, somos brasileiros. Algo parece sempre impedir a comunidade com os outros: grosso modo, aqui o traço corporal; lá o traço cultural. Em ambos os casos, carregamos algo que não nos põe nunca inteiramente nem com os daqui nem com os de lá, mas sempre pertencendo a um outro lugar. Estrangeiros onde estivermos. O próprio termo "nipo-brasileiro" (que evitamos utilizar aqui, preferindo o termo "nipo-descendente"), pode muitas vezes supor uma identidade por demais bem resolvida, escondendo as muitas contradições que esperimentamos.

Para alguns, não é apenas a motivação econômica o motivo de sua viagem: muitos vão em busca de uma experiência direta de suas raízes japonesas, daquilo que em sua vida no Brasil não se completa enquanto fomos herdeiros distantes de um passado que veio precariamente pelos avós, pelos pais e tios, irmãos e primos. O Japão aparece como um bem de outra ordem, diferente da econômica, difícil de nomear, mas que pode ser decisiva, central até, no momento de decidir-se pela viagem. A viagem para o Japão fica como que imantada pela esperança de consolidar uma "identidade de trânsito ou troca" como uma identidade balanceada e feliz, contra a identidade dilemática e angustiante do permanente estrangeiro. Ou, mais radicalmente, o Japão parece ser a promessa de consolidação de uma identidade estrangeira sem dilaceramento: nem perfeitos brasileiros, nem perfeitos japoneses, somos feitos de dois mundos sem nos confundirmos com nenhum. Há um vínculo e uma distância que, afinal, qualquer um de nós quer amadurecer com o seu país, para que a relação ente o nativo e sua pátria não seja a relação do exilado com a pátria que o exila, mas tampouco seja uma relação de servidão ou de coincidência sem liberdade.

Desde seu início, em 1908, a imigração japonesa para o Brasil tem sido descrita e 
investigada tanto por pesquisadores acadêmicos quanto por escritores interessados em registrar aspectos de sua história. Eis o que retiramos de Célia Sakurai: a maioria dos trabalhos acadêmicos, especialmente até os anos 50, obedece à tendência de dizer que, mesmo com dificuldades, os japoneses são uma etnia que "deu certo no Brasil”, a mesma tese sendo sustentada nos romances escritos pelos descendentes, obras em geral feitas na intenção de homenagear os pioneiros e dar lições a respeito do "ser japonês" aos mais jovens. Todavia, estes textos que escoram traços ideológicos e informam o senso comum, apoiando a imagem dos japoneses como esforçados, leais, trabalhadores, apegados à terra e à família, bem-educados, não deixam de nos auxiliar, segundo a autora, na compreensão do processo de enraizamento japonês no Brasil: "Pensar a trajetória dos imigrantes japoneses no Brasil é reconstituir a história de uma etnia fortemente marcada pela herança de seu povo de origem. Através do espírito do gambatê [algo como 'esforço perseverante, resignado'], os japoneses e seus descendentes conseguiram perpetuar as raízes culturais de seu povo, mesclando-as com valores ocidentais, mas mantendo os valores básicos do 'espírito japonês' através da honra, dignidade e honestidade."

Os imigrantes que aqui chegaram foram socializados dentro dos padrões educacionais da Restauração Meiji, marcados pelo resgate dos valores e da singularidade étnico-cultural japoneses (a homogeneidade imutável da raça, a diferença radical com outros povos, o nacionalismo). Célia Sakurai nos auxilia novamente: "Os imigrantes que chegaram ao Brasil estavam imbuídos do espírito de que eram diferentes. (...) o Japão e os japoneses eram uma grande unidade, uma família em busca do wa [harmonia]. (...) quando o colono trabalha até aos domingos em sua horta, quando a mulher japonesa se desdobra entre o trabalho doméstico e o trabalho com o marido, estão trazendo à tona aspectos do que consideram os passos para serem "bons japoneses"”.

A possibilidade da manutenção dos laços com a terra natal foi uma possibilidade concreta para todo imigrante japonês no Brasil e um fator de unidade entre gerações: as famílias que aqui chegavam permaneciam juntas, comunidades japonesas formaram-se livremente, a falta de identificação com a cultura brasileira, os planos de retorno após enriquecer eram comuns a todos e a intenção resultante de preservar seus laços culturais com o país de origem. Desde o início, o reconhecimento oficial de sua condição 
imigrante garantiu-lhe uma autonomia e um usufruto de direitos inimagináveis para negros e índios até então e, mesmo considerando o período violento da política de assimilação de estrangeiros do governo Vargas ou da guerra, não se pode dizer que o japonês foi, ao contrário dos dois últimos, vítima do mesmo tipo (ou grau) de violência que espoliou seu passado. Sobretudo a partir do fim da II Guerra, com a perspectiva definitiva de ficar e fixar raízes na nova terra, as manifestações culturais japonesas ganharam grande visibilidade, saindo do círculo dos imigrantes e descendentes, mostrando que ali se mantiveram vivas para surgirem e serem reconhecidas como "contribuições" à cultura local - fato histórico que se constitui num bem moral inestimável, mas que alimentou a ideologia da "etnia que deu certo".

As "contribuições" da "etnia que deu certo" parecem querer pintar um quadro limpo demais de contradições em sua história, que não satisfaz o descendente interessado em compor/recompor suas raízes. A cultura japonesa muitas vezes assumiu formas sem densidade, fora de contexto, sem uma compreensão que desvendasse sua formação e necessidade, as condições concretas de sua conformação, causando assim em quem as aborda um efeito de estranheza ou de encontro com mera curiosidade (o consumo fácil das "festas folclóricas") que beira o tristemente caricato: o japonês como um "tipo". Era comum, entre os nikkey com quem convivi nos tempos de segundo grau, a adoção de uma atitude de segregação contra o grupo dos "gaijin" ("estrangeiros"): os brasileiros eram afastados, mas também os nikkey que não cultivassem uma atitude de orgulho e soberba por serem ligados a um país e uma cultura tidos como superiores ao Brasil, país pobre de terceiro mundo.

Difícil, assim, estabelecer alguma comunicação com aquilo que chegou até nós através daqueles filhos da era Meiji, mesmo para aquele que conviveu longamente com a cultura japonesa (por relações familiares onde várias gerações se fazem presentes, por engajamento voluntário em práticas culturais). O Japão brasileiro parece feito, às vezes, de tristes enganos.

Noutras vezes, e contrariamente, de uma saudade, o Japão brasileiro é feito da persistência da memória: 
“Academia, disputa, camaradagem, mais coisas. Lá na Liberdade encontrei o ótimo Toshitaro. Nunca vi ninguém como. Costumo dizer que o sujeito que não se der com Toshitaro não presta. Ou não conhece Toshi.

Eu nunca havia sentido nada pelas coisas do Japão. Levou-me a beber sakê nos restaurantes da Liberdade, mostrou-me cinema. Depois gravuras, depois pinturas, tatuagens. Fui atingindo a dimensão mística de todas aquelas belezas. Percebi, por exemplo, que naquelas mulheres passivas e tímidas e afáveis, mexendo-se dentro de quimonos enormes, quase aos pulinhos, e que o cinema me trazia entre neves e casas do Japão, morava um mundo diferente de sensualidade. Poesia naquelas coisas.

Gostei. Como quem descobre uma maravilha gostei. Não me arredava daqueles ambientes. Gostei demais. Judô, folclore japonês, depois teatro, fotografia.

Aquilo, sim, meu Deus, era um mundo!”.

O Japão muitas vezes desenha-se como um conjunto de imagens difíceis de fixar, mas fortíssimas em seu atavismo. Parece corresponder a uma profunda e inominável aspiração de homem do povo, aqui retratado neste trecho do conto Fujie, de "Malagueta, Perus e Bacanaço" escrito por João Antônio, sobre um menino da Penha e seu convívio com os japoneses da Liberdade. Se a herança de nossos avós orientais pode ser assim para o brasileiro que se abra para sua experiência, o que não poderia ser para nós, nikkeys? São os seus modos, seu senso de humor, seus silêncios, diferentes das pessoas daqui. Suas histórias e memórias, suas saudades de lugares e comidas, festas e datas, da infância, dos pais e de bons amigos que lá ficaram. Tudo coisas que nós jovens não vivemos, mas aprendemos a amar também.

A motivação econômica dekassegui pode comportar assim motivações de recomposição psicocultural, reencontro de raízes mais ou menos partidas que pedem consideração e que excedem as motivações apenas econômicas e apenas ideológicas, embora possam incluí-las.

A experiência humana singular que se sintetizou no arquipélago japonês, a terra da harmonia dos contrários, do crisântemo e da espada; o Japão dos tempos míticos, espírito ao mesmo tempo grandioso, terrível e metafísico das telas de Mabe; dos samurais, ideal de homem apenas comparável ao grego; das singulares bases históricas e 
culturais, religiosas e éticas, políticas e intelectuais, dos símbolos. Japão da eternidade e da impermanência, enigma deslumbrante.

Que é esse desejo pelo passado, esse anseio pela raiz? É este desejo, esta outra motivação dekassegui atendida ou frustrada? Tem ela lugar nessa experiência? E mais: pôde este desejo surgir mesmo naqueles que se motivaram primeiramente pela necessidade econômica? Pode surgir naqueles que têm sua imaginação dominada por arrogante ideologia? O que passa a representar raiz brasileira? Como as duas culturas puderam aparecer uma para outra? 


\section{OBJETIVOS}

Esta investigação quer pôr à prova as duas seguintes hipóteses:

1) O dekassegui vive uma experiência de desenraizamento no Japão (a) por força de trabalhos subalternos e simples que lhes são impingidos e (b) por experimentar, ainda que na condição de nissei ou sansei, um estranhamento e às vezes hostilidade por parte dos japoneses, quando paradoxalmente pretendia só viver a hospitalidade entre eles;

2) Os motivos de um dekassegui não são equivalentes: há os motivos estritamente econômicos; há os motivos ideológicos comprometidos com imagens ou idéias parciais ou mesmo falsas acerca do Japão e dos japoneses; e há motivações densas que, incluindo, mas também superando motivações econômicas e ideológicas, parecem mais genuinamente corresponder ao anseio de enraizamento: anseio que inclui igual lealdade ao Brasil e ao Japão, anseio por balanceada identidade nipo-descendente, anseio por uma "identidade de trânsito ou de troca" em lugar da angustiante e dilemática "identidade do sempre estrangeiro" (o estrangeiro permanente, japonês no Brasil e brasileiro no Japão).

Para tanto, concebemos os seguintes passos:

キ Reconstrução autobiográfica a partir de observação participante (o próprio pesquisador viveu oito meses a condição dekassegui);

キ Análise do depoimento autobiográfico.

\section{METODOLOGIA}

Partindo da experiência do próprio pesquisador, vai-se fazer uma reconstrução, sob a forma de narrativa, do período em que este viveu na cidade de Fujinomiya (Japão) como trabalhador em duas indústrias pelo tempo aproximado de oito meses, de março a novembro de 2000 , bem como de marcos biográficos que 
precederam e sucederam este período. Procuramos cumprir aqui, entre outras, a exigência metodológica tanto etnográfica quanto gestaltista de exposição do pesquisador à totalidade do fenômeno estudado, por um período relativamente longo de tempo.

Este é um estudo qualitativo em Psicologia Social, cujo foco está na experiência da pessoa na condição dekassegui no Japão e na possibilidade dessa situação apoiar e satisfazer o anseio por uma experiência das raízes partidas. Uma motivação portanto de ordem psicossocial: experiência de recomposição da identidade cultural cujas motivações superam as econômicas e com elas se coordenam ou tencionam, prevalecem ou submergem.

A escolha de uma metodologia de pesquisa deveria supor sempre sua adequação ao objeto de estudo, nunca o contrário, regra de ouro sugerida por Ecléa Bosi ${ }^{3}$. Daí que para a compreensão de fenômenos sócio-históricos, estamos diante fenômenos intersubjetivos sempre significativos, portanto da necessidade de uma metodologia que permita-nos realizar uma descrição de estruturas ou campos de significação.

É referência desse trabalho as idéias da Psicologia da Forma sobre estrutura e percepção dos fenômenos humanos: os comportamentos e gestos ocorrem sempre dentro de campos de significação, de estruturas significativas de que fazem parte o percebedor e o objeto percebido, sendo a percepção resultado da maneira pela qual ambos se interrelacionaram, a própria situação viva em que ambos mantiveram comunicação, se moveram no espaço e no tempo. A percepção é o que cresceu, o que se organizou, o que se constituiu entre ambos, unidade de um ser e seu sentido.

É neste campo de relacionamento que a densidade de um fenômeno, as diferentes formas pelas quais os homens assumiram seu relacionamento entre si e a natureza, se deixa alcançar: portanto, por alguma forma de engajamento direto do pesquisador nas dimensões concretas do fenômeno. Concreto que é síntese de múltiplas significações variáveis no tempo, vivência de um fenômeno em seu centro vivo.

A compreensão de um fenômeno faz-se na interpretação de suas múltiplas estruturas de significação, que muitas vezes não se apresentam de maneira imediata (permanecem como informação de fundo); menos ainda a um olhar que tome seus

3 Idem, ibidem. p55. 
elementos isolando-os de seu relacionamento com o campo total de sua constituição. Daí ser necessário a longa e paciente exposição do pesquisador à totalidade do fenômeno estudado, de modo a revelar-se, nesse tempo, aquilo que a um olhar distante ou apressado nunca se revelaria.

A concretude de um fenômeno cresce também com a narrativa de sua apresentação, pela referência ao que não se dá diretamente à experiência sensível, mas está ali, como dimensão fundamental.

O trabalho é uma reconstrução, através de narrativa, da experiência de trabalho do pesquisador em duas fábrica japonesas de março a novembro de 2000 e das memórias do que antecedeu a viagem mas marcou, de algum modo, a consciência de uma ascendência nipônica. Busca comunicar-se com a experiência dekassegui através do trabalho da memória, que orienta a narração.

A memória não é repetição, é reencontro com o vivido. Empenha pensamento, mas também sentimentos, imaginação, percepção. Recordar é trabalho, que é abertura e fidelidade ao outro, ao que aconteceu, com suas contradições e enigmas, seus detalhes importantes e significados ocultos. É exame, elaboração, reconstituição a partir de um ponto de vista presente e que revive. O trabalho da memória guia, põe o depoente em contato com o concreto, resiste àquilo que pôde ter ficado ofuscado por idéias estereotipadas, ideológicas ou dominantes e estabelece, soberano, um ponto de vista pessoal - se afasta dos sentidos abstratos e se apega ao mistério do mundo, nos põe em relação com ele, ainda que por vezes isso nos desoriente.

Narrar passa a ser, então, atender às exigências da memória.

Neste estudo, a narrativa privilegiará as funções referencial, emotiva e poética da linguagem - referencial: será orientada para seu contexto, para aquilo a que se refere, para o que se recorda; emotiva: além disso "visa a uma expressão direta da atitude de quem fala em relação àquilo de que está falando", ponto de vista, o ponto de vista do pesquisador engajado nas situações narradas, com seu impacto subjetivo; poética: será ainda atenta para a expressividade da mensagem como tal, sua força para transmitir mais ou menos fielmente os episódios narrados: atenta a modos, cenas, falas, perspectivas, vozes, tempos.

4 Jakobson. Linguística ecomunicação. S.Paulo: Edusp, 1969 
A ênfase na narração privilegiará a sintaxe clara, a estrutura linear e bem construída, orientada para o contexto, o mundo fenomênico e seus significados, o objeto evocado: a memória que será nosso referente. Ao mesmo tempo, a narrativa será expressão daquele que fala, vai procurar incluir o leitor numa certa atmosfera expressiva, em que as intenções e a subjetividade do narrador se pretendem transparentes, mostrando os traços de sua relação com o lembrado (o referente), marca inequívoca do texto orientado pela função emotiva. E, ainda, pela própria exigência das tarefas anteriores e articulada a elas, vai-se buscar o trabalho atento da escrita: a seleção e combinação dos signos, buscando equivalências e contiguidades que, em seu arranjo e fluxo verbal, revelem, num aparecer, os sentidos daquilo sobre o que se fala - função poética. Neste caso, alguns apontamentos sobre a narração:

No caso desta reconstrução o narrador aparente indica o modo do "contar", privilegiando cenas, falas narrativizadas ou transpostas, detalhes e visualização diferentes assim do modo do "mostrar", onde o texto se constrói com a intenção de ocultar aquele que narra, criando a ilusão da presença imediata do leitor no narrado. Narrativa feita na voz de um personagem, presente na história que conta e portanto com perspectiva definida ( e não um narrador estranho àquilo que narra, ausente da história que conta, que vê "de fora" ou "tudo vê"). E com tempos que tendem a pouco se utilizar de recursos que acelerem o tempo real da história, como elipses e sumários.

O trabalho de reconstrução autobiográfica realizou-se a partir de entrevista concedida pelo próprio pesquisador. A entrevista, um trabalho de reconstrução autobiográfica contou com o orientador como entrevistador, que baseou-se num roteiro de questões previamente elaborado a partir de um conjunto de marcos cronológicos. Houve uma primeira evocação e registro de marcos cronológicos em conversa livre com o orientador, seguindo-se então um trabalho de organização temática e a elaboração de questões para o desenvolvimento narrativo de cada marco.

Os marcos cronológicos, escritos sob a forma de temas (sentenças curtas), quiseram primeiro registrar episódios da história pessoal do pesquisador que balizaram sua identidade nipo-brasileira e que, assim, pareceram decisivos na compreensão das motivações para sua viagem ao Japão na condição dekassegui. Em seguida, episódios da viagem mesma e do retorno ao Brasil foram também registrados. 
A estes marcos cronológicos foram então associadas questões capazes de suscitar no depoente um trabalho da memória. Cuidamos em favor de questões sempre construídas de maneira a convidar o depoente a uma "narrativa" e freqüentemente empregamos o verbo "lembrar" nas perguntas dirigidas ao depoente. Portanto: a) evitamos questões que buscassem opiniões ou sentimentos diretamente, o que forçaria um depoimento demais ideológico ou demais emotivo, subjetivo (um depoimento opinativo ou confessional, desligado da recordação de episódios concretos); b) privilegiamos questões capazes de suscitar sobretudo lembranças e, desde então, opiniões ou sentimentos formados na nervura dos fatos evocados.

Os quadros com os marcos cronológicos e as questões deles derivadas serão apresentados no anexo I.

A entrevista autobiográfica foi transcrita pelo pesquisador e editada sob forma de um texto contínuo, acompanhados de trechos de análise em que se procura articular o depoimento com as hipóteses de trabalho.

A partir do trabalho de reconstrução autobiográfica, houve a possibilidade de interpretar e elaborar o depoimento memorialístico de modo a se elencar aquilo que constitui-se como signo forte da experiência dekassegui, ou seja, situações e vivências que, por seu caráter esclarecedor ou enigmático, parece exigir maior atenção, interpretação e/ou elaboração e que são privilegiadas para o entendimento dessa dada condição. São aqueles episódios que parecem reveladores ou, ao contrário, que intrigam e pedem atenção; passagens que ficam na memória. Aqui, também, o momento da elaboração de novas hipóteses a esse respeito.

Vai-se buscar analisar a narrativa de modo a discriminar, organizar e relacionar fatos significados, episódios em que não se perca comunicação com a totalidade da narrativa. Interpretar, aqui, "é analisar e compor o depoimento, discriminar idéias, fenômenos e relacioná-los, progredindo no esforço de melhor atinar com o ponto de vista do depoente e também progredindo na compreensão do que o depoente dá a pensar. Interpretar é reconhecer pensamentos manifestos e latentes no depoimento, é frisar o que o depoente parece pensar e é também completar caminhos de pensamento 
que o depoente dispara, orienta, mas não perfaz",.

A entrevista com roteiro procurou, enquanto opção metodológica, garantir ao depoente liberdade para seguir um ritmo próprio de pensamento enquanto recorda, $o$ que um questionário fechado não permitiria, ao mesmo tempo em que poderá garantir-nos contra o risco contrário, o do depoente perde-se da tarefa de lembrar o que foi vivido, afastando-se da memória do que experimentou para aderir a abstrações ou sentidos já cristalizados a respeito do que narra. Procuraremos criar condições para uma narrativa pessoal, significativa para o depoente, que o empenhe na tarefa de lembrar.

Com as primeiras hipóteses e o inventário temático haverá elementos para, em futura pesquisa a ser desenvolvida em regime de doutorado, a saber: a construção de um roteiro de entrevista de longa duração a ser realizada com pessoas que, por motivações que parecem ser aquelas que aqui investigamos, expuseram-se à experiência como trabalhador no Japão; roteiro que privilegie a tradução dos temas em perguntas que fomentem um longo e paciente trabalho da memória do depoente sobre sua participação em determinada condição humana, respeitando a dignidade comunicativa desta pessoa que narra: ela não será tomada como objeto de estudo e não terá sua fala abordada como objeto a ser examinado apenas pelo pesquisador ou seus autores de referência, mas será também tomada como autora, ela também alguém que interpreta enquanto lembra e que participará decisivamente no resultado final da pesquisa.

5 Gonçalves Filho, José Moura. Texto não publicado cedido pelo autor. 


\section{RECONSTRUÇÃO AUTOBIOGRÁFICA:}

Aqui procuro narrar marcos e sinais biográficos que podem indicar a formação de um impulso que mais tarde se conformou como um desejo de ir ao Japão. Em meu caso, o desejo de ir ao Japão encontrou o projeto de uma experiência dekassegui. Isso significa que há nesta experiência, portanto, uma preocupação com as raízes nipônicas a dirigir a viagem ao Japão - motivação que pode não ser comum a todos os dekassegui. A viagem está, portanto, ligada à uma perseguição pessoal de identidade.

Narro também episódios de minha experiência como trabalhador dekassegui, as memórias mais significativas do que prevalece ou submerge, do que se coordena ou tenciona entre as diferentes motivações de um nipo-descendente operário no Japão.

\section{ANTES DO JAPÃO:}

\section{Meu pai}

A lembrança mais remota que poderia assinalar um começo de consciência sobre minha condição nipo-descendente é, certamente, a de meu pai: Shim Watanabe, filho de pais japoneses que aqui chegaram em 1939 e viveram seus primeiros anos nos cafezais de Santa Cruz do Rio Pardo.

Foi o único dos sete filhos de Saburo e Toshimi a nascer no Brasil. O mais novo que, apesar de nascido aqui, foi registrado também como cidadão japonês por exigência de meu avô, imigrante que como os outros tinha planos de retorno à terra natal depois de algum tempo de trabalho aqui poupando dinheiro. Também eles, dekasseguis: do japonês deru (sair) kassegu (para trabalhar). Quando nasci, meus avós paternos já eram falecidos.

Shim formou-se técnico em contabilidade, trabalhou nos Diários Associados, acessorando um de seus diretores, Edmundo Monteiro, e depois na recém inaugurada TVS de São Paulo, onde se aposentou por invalidez, decorrente dos sérios problemas de saúde advindos do consumo excessivo de álcool. 
Convivi pouquíssimo com meu pai, pouco sei de sua história: ele e minha mãe separaram-se quando eu tinha por volta de três ou quatro anos. As duas famílias mantiveram-se afastadas. As lembranças são poucas e precárias. Mas lembro-me de sua figura: magro, rosto redondo. Nas fotos que tenho, parece ser bem humorado; nas minhas impressões, pessoa cuja seriedade inspirava respeito.

Tenho lembranças de um aniversário meu - lembranças? Imagens, que em mim se sustentam apoiadas por fotos da época - aniversário em que as duas famílias se reuniram num raro, raríssimo acontecimento, que talvez nunca mais tenha acontecido. E o que nesse dia se revelou foi a diferença física: meu pai e uma parte das pessoas da família eram diferentes das outras pessoas da família, eram "japoneses". Ele e eu também. A diferença - física - se fez; mas a identidade - de alma - também: entre eu e ele, entre eu e aquelas pessoas, entre eu e minhas duas famílias. Havia meus tios e primos, brasileiros e japoneses, convivência, riso, brincadeiras comigo, entre si, algo bom - encontro.

Me lembro da primeira vez em que fui na praia com ele e minha mãe: pai e filho, na acompanhia da mãe brasileira, os únicos japoneses na praia. Lembro de minha vontade de ir pro mar enquanto meu pai me segurava com ele, eu ficava um pouco e já saía para brincar junto à água, entusiasmado com a novidade da praia, mas sem sua companhia porque ele queria ficar sob o guarda-sol. Me lembro dele querendo que eu ficasse e eu querendo me soltar, minha mãe me pedindo pra ficar um pouco. Me lembro das pessoas à volta se divertindo com nossa brincadeira. Apenas brincávamos: eu tentava me desvencilhar de seu abraço para ir para a beira do mar, ele tentava me manter nos braços, para brincar perto dele - espécie de "judô" dos Watanabe.

Houve um momento em que ele se cansou de insistir e severo, mesmo bravo, me fez ficar lá - meu samuraico pai. Relaxou quando fiquei com ele, voltou a sorrir. E foi bom brincar ali também.

Enquanto brincávamos, uma senhora parece ter se encantado com o pai japonês e seu filho, arriscou algum comentário com minha mãe - me elogiava? Confirmava se éramos uma família? Não me lembro. 
Ser percebido como japonês não era algo que ele pretendesse afirmar: não negava mas também não assinalava a descendência óbvia exposta em nosso rosto. Era percepção que vinha dos outros, nunca por iniciativa dele. Não me lembro de comigo ter feito qualquer referência ao fato de sermos japoneses, em nenhuma ocasião: não contava histórias japonesas, não falava comigo em japonês - nem sei se tinha alguma compreensão da língua. Anos depois, já adulto, ouvi de minha mãe que ele não era uma pessoa interessada na cultura japonesa: pelo contrário, vivia distante de suas raízes nipônicas pois parecia reencontrar na cultura japonesa sua história familiar: guardava ressentimentos em relação ao meu avô, homem severo e exigente, pouco afetuoso, com quem não se dava mas de quem teve que cuidar na velhice. $\mathrm{E}$ - ao que parece - obrigado por alguns dos irmãos. Velhos costumes de família japonesa se impondo ao filho que escolhera para si o Brasil?

Depois disso, tenho poucas recordações de meu pai. Me lembro de discussões dele com minha mãe em que estive presente, episódios que marcaram sua separação, e depois disso nada mais. Me lembro de um dia em que pensei vê-lo pelo vidro fosco da casa viera buscar seus últimos objetos pessoais? Viera me ver? - tento sair em sua direção mas sou contido por meus irmãos, que me diziam que não era ele. Não houve conversas sobre a separação, nunca ouvi desde então quaisquer histórias sobre tempos felizes, namoro e casamento de meus pais; não se falou mais nele, e ele nunca me procurou. Fui reencontrá-lo, e também minha família paterna, seis ou sete anos depois, aos dez, quase onze anos de idade, por iniciativa de uma tia que sabia que o irmão já estava gravemente doente.

Nesse reencontro ele já era bem diferente da pessoa que conheci e via por fotos. Já estava muito doente. Até então o que eu tinha dele eram alguns poucos traços na memória, fotos e um pacote de jornais que ele fechou e deixou com minha mãe, para ser entregue e aberto por mim quando eu fizesse dezoito anos: os jornais publicados no dia 8 de janeiro de 1974, dia do meu nascimento. Esse era um dos poucos objetos que tinha como lembrança de meu pai: jornais brasileiros, de que ele gostava tanto. Quando minha tia Elza, sua irmã, me levou para vê-lo, fui recebido por um senhor envelhecido, muito 
magro e fraco, roupas claras, simples e leves, aspecto maltratado e sem viço. Cumprimentei-o com certa desatenção, entrei na casa já ansioso para ver meu pai e, apenas quando percebi que não havia mais ninguém ali, entendi que aquele senhor era ele - e não algum amigo ou tio distante.

Nos encontramos outras duas vezes, antes de seu falecimento: na casa da minha tia Elza, ocasião em que ele se encontrava muito debilitado pela doença e, novamente, mal conversamos. Um gesto me marca: faz questão de levantar-se, ao menos sentar-se na cama para conversar comigo, mas pouco aproveitamos o encontro pois minha mãe mostra-se preocupada com ele - a cirrose hepática e o diabetes o debilitavam ainda mais e rápido vamos embora. $\mathrm{O}$ outro encontro foi em Itanhaém, na casa de praia da mesma tia. Ele ficava distante, deitado a maior parte do tempo, estava cada vez pior, mal nos falávamos. Um dia, quando ele foi para a frente da casa enquanto todos jogavam cartas na cozinha, uma prima me exorta: "Vá ficar junto com teu pai!”. Fui e, acho que quase o tempo todo, fomos duas figuras caladas, constrangidas, em silêncio na varanda da casa.

Desses encontros após tantos anos sem nos vermos, me lembro de sua preocupação - coisa comum entre famílias japonesas - com meu desempenho escolar, se eu me saía bem ou não; mas também da mútua timidez, dos silêncios, da falta de liberdade para brincar, brigar, ambos sem saber o que dizer ou perguntar - enfim, como se aproximar. Não nos aproximamos.

A primeira marca de minha relação como as raízes japonesas é mediada pelo pai. Porém ele aparece como um homem que não se liga ativamente ao Japão, à família japonesa, ao filho. Não recusa mas não sustenta com energia nenhum desses vínculos: estes são contidos, fracos e sem cultivo. O filho quer ir pro mar - porque ele não vai também? Sete anos se passam - porque sem notícia? Pai de pouca atividade, com uma ligação pouco consistente com o Japão, com o próprio pai e com o fillho. O pai não ia atrás do Japão, do próprio pai e do filho o bastante, embora os vínculos com os três contassem, existissem pra ele.

Há algo que faz a percepção social de meu pai como japonês que, se não representa uma percepção inóspita, em todo caso indicava uma meia integração entre ele e o Brasil, já que ele não tinha a fisionomia característica de um brasileiro e no entanto 
existia um vínculo com o outro que não era, de novo, íntegro, completo. Ele é percebido como um estrangeiro, mesmo que essa percepção não seja acompanhada de hostilidade. Não é percepção de identidade, mas percepção de diferença - coisa que eu também vivi mas de que ele nunca tratou comigo.

O que parece ter sido então minha experiência das raízes é mais propriamente um impedimento, um enigma: o que é ser japonês ou descendente de japoneses? Por isso o Japão apresentou meu pai mais do que meu pai tenha me apresentado o Japão: quando por exemplo reconheço certos traços dele com maior nitidez quando pareceu-me ter reencontrado esses traços nos japoneses, lá. Certa sobriedade, circunspecção, economia de palavras, a maneira delicada e discreta de expressão de afeto, o rigor e disciplina na ação, a aplicação em cada tarefa. Os japoneses, que conheci aqui e lá, reapresentam meu pai.

\section{Minha mãe}

O pai é o primeiro mediador dessa ligação com a ascendência japonesa e o Japão. Eu quis ir atrás dele quando achei vê-lo. Depois isso se desmanchou porque ele morreu duas vezes - ausentou-se como quem morre por sete anos, para morrer de novo quando fiz onze anos, sem que tivesse se decidido a não morrer para mim. Precisou de outros para me ver de novo. Eu fiquei com aquela que era ligada ativamente a mim - inclusive ao Japão - minha mãe. Mimava e se orgulhava do filho "japonesinho", que levava ao trabalho, que apresentava às amigas; brincava comigo que um dia eu iria levá-la até lá, país que ela sempre disse admirar, despertando o filho para o bem de sua herança. Ela apoiou meu vínculo posterior com o Japão e os japoneses porque era ali com ela que havia um vínculo ativamente cultivado para apoiar meu crescimento e desenvolvimento.

Maria de Lurdes é pernambucana e veio para São Paulo em 1970, com os três filhos de seu primeiro casamento. É filha de Severino Carneiro, comerciante, homem forte e respeitado de sua cidade, e Amara Rocha da Silva, em nossa família "Dona Santa". Em São Paulo conheceu Shim. Sou o único filho do casal.

As lembranças que tenho de minha mãe estão sempre fortemente marcadas pelos 
lugares em que moramos aqui em São Paulo. Entre as dificuldades comuns entre os migrantes na cidade está sempre aquela ligada à moradia, e em nossa família as coisas não foram diferentes. Certa vez, há três anos, na feliz época em que ela pôde finalmente ter a própria casa, juntos refizemos o roteiro dos lugares onde moramos na grande São Paulo: Luz, Imirim, Freguesia do Ó, Santa Cecília, Praça da Árvore, Santa Cecília, Guarulhos, Pinheiros... Além dos endereços em que, já separada dos filhos, também morou: Caruaru, Mogi das Cruzes, Aclimação, Bertioga... Ela conseguia se lembrar de cada endereço, de cada casa.

Tenho especial carinho por uma dessas casas onde moramos. Ouvindo meu relato, um amigo a batizou de "casa da aliança". Foi a segunda casa de minha infância e ficava na Freguesia do Ó. Era maior que a primeira casa, onde meu pai ainda viveu conosco, no Imirim: ampla, jardim na frente, três pavimentos; o térreo que dava pra rua, a parte de cima com os quartos e a parte de baixo com um quartinho e o quintal onde minha mãe fez um milharal e uma horta. Morávamos eu, minha mãe e meu irmão Cláudio. Minha avó, ajudando a nos criar, estava o tempo todo com a gente, pois sua casa era quase vizinha.

Casa hospitaleira, enorme para a criança que eu era, onde podíamos brincar na rua, uma ladeira que descíamos de triciclo, em tábuas ou rolimãs. Me lembro que minha mãe plantou uma horta: nas minhas tentativas de ajudar a cuidar, pisoteava as plantas não sabia quais eram as de comer ou não, ela me orientando (meio rindo, meio brava com meu entusiasmo) onde eu podia ou não pisar. Lembro também que meu irmão certa vez "tomou posse" do quartinho dos fundos da casa, que servia como uma espécie de depósito: móveis velhos, latas de tinta, ferramentas, caixas e mais caixas. Passou uma tarde lá e, quando acabou seu trabalho, levou eu e minha prima para uma passeio no "trem fantasma" que havia criado: teias de aranha, fantasmas de lençol, sons horripilantes gravados numa fita. Me diverti muito naquela tarde, admirado com aquele cenógrafo genial, agradecido por ser o estreante da atração.

Na Freguesia do Ó meu pai já não existia - na memória, nas falas, na presença de parentes - não havia visitas, histórias, comentários.

Lá, com quatro, cinco anos, vi pela primeira vez um arco-íris. Eu estava com minha mãe em casa - sempre foi raro, por causa do trabalho, um dia em que ela estivesse em casa numa tarde comigo, tranqüila. Estávamos juntos, não sei como conseguiu estar lá 
naquele dia. Chovia muito e eu não podia ir para a rua brincar, nem queria. A gente ficou no quarto, na parte de cima da casa, olhando pela janela que tinha uma vista larga, com horizonte. A chuva de verão - forte, com trovões poderosos que não temi porque estava com ela - foi passando, o sol foi aparecendo e aí se formou o arco-íris: enorme, a curva completa, bem nítido à nossa frente. Fiquei admirado, foi um espanto. Minha inteligência confiante de criança achava até então difícil que pudesse existir mesmo arco-íris. Se existisse, era coisa raríssima!

Havia um doce, que nem sei mais qual é, mas que eu adorava e que quando ela nos trazia tinha que me proibir de comer além do que era minha justa parte na divisão, senão eu comia tudo, não sobrava para ninguém. Nesse dia havia do tal doce em casa e eu, um pouco com medo da negativa - já tinha comido minha parte - perguntei se podia comer um. Ela deixou. Eu desci rápido por causa do doce, peguei um, felicíssimo, subi rápido por causa do arco-íris e de novo e fiquei ali, com ela, olhando.

"Posso comer outro?".

"Pode".

Assim foi: mais um, mais outro... Ela, sorrindo para o meu subir e descer atrás do doce de que eu tanto gostava, me disse para pegar logo tudo, para ficar ali, olhando com ela. Que alegria! E ficamos lá, em silêncio, encantados com o desenho colorido no céu. Não estava errado: arco-íris são raros.

Lá fui pela primeira vez à escola - minha mãe tem as fotos de mue primeiro dia de aulas até hoje, são algumas de suas preferidas. Me matriculou, comprou o uniforme. Foi uma enorme alegria para ela saber, no fim do dia, que eu gostara demais!

Nessa casa me lembro também de outros dois episódios: num determinado momento daquele inverno, o frio intenso não me deixou dormir por mais de uma noite. Ela tentava me proteger, com roupas e cobertores, mas eu acordava resfriado, sem saber porque, e com dores nas mãos. Empenhada, descobriu que, durante a noite eu me mexia na cama e minhas mãos acabavam expostas ao frio - aí a causa da dor que eu não sabia identificar, e do resfriado também. Na noite seguinte, enquanto eu dormia, vestiu-me as luvas de lã que havia comprado durante o dia. Acordei bem, depois de uma noite confortável. E - surpresa! - mãos aquecidas pelas luvas! Perguntei o que havia acontecido e encantado descobri, pelas palavras dela, que o Papai Noel havia me visitado fora da 
época de Natal. Até hoje, luvas simples da lã me são signo de conforto materno, de bondade.

Noutra vez, minha primeira lembrança do mundo do trabalho: esperávamos eu, meu irmão e minha avó, como era nossa rotina, pela chegada dela. Espera feliz que precedia nosso jantar. Mas, naquele dia, chegou triste e sem conseguir segurar o choro: havia sido descontada de seu salário, porque seu caixa - função que havia assumido para substituir uma colega de loja - não havia batido os valores na conferência. O sentimento da justa indignação do militante que me tornei tem aí, no menino de cinco anos, sua recordação mais distante: depois dessa noite queria até, nas vezes em que a visitei no trabalho, saber quem era e onde estava seu chefe, para brigar com ele - "minha mãe jamais faria aquilo, quem ele pensa que é?", pensava.

Quais as preocupações de minha mãe com casa, com morar? Suas memórias tão claras dos lugares em que viveu são significativas. Tantas vezes fizemos mudanças de casa que não queríamos, tantos vizinhos queridos ficaram para trás... Uma das maiores alegria que já testemunhei foi quando ela pôde comprar sua casa em Boracéia, litoral de São Paulo. A alegria dela era também a minha e, de minha parte, havia também profundo alívio, por saber que agora ela tinha um lugar pra si. Minha mãe sempre trabalhou no comércio de São Paulo: na Mesbla, no Mappin, no comércio de móveis e decorações. Foi vendedora por muitos anos, vivendo de comissões por produtividade. Chegou a gerenciar lojas, muito querida dos patrões, no entanto exigentes, implacáveis, quase cruéis no cumprimento das cotas de vendas que ela deveria cumprir ou fazer cumprir. Hoje ela tem sua própria loja na frente de casa, criando com um ofício aprendido com sua mãe - a costura - seus produtos artesanais: bonecas, tapetes, enfeites. "Chega fico perdida de tantas idéias que tenho e não dou conta de executar!”, diz.

Há pouco tempo descobri que minha infância foi protegida das dificuldades que ela, migrante nordestina em São Paulo, tantas vezes teve que passar. Por muitas vezes andou a pé quadras e mais quadras da cidade para economizar o dinheiro da condução. $\mathrm{O}$ sanduíche que eu e meu irmão comíamos com tanto gosto não sabíamos o quanto custava: ela guardava o presunto e o queijo dos sanduíches que recebia no trabalho para nos trazer, pois não tinha como comprar e sabia que gostávamos. Ela que viveu para que 
alguém vivesse.

Me lembro da tristeza dela quando não poderia me dar o que eu queria e ao mesmo tempo da raiva por eu querer tanto o que queria: os brinquedos na infância, a participação no início da juventude. Me lembro da humilhação adolescente por não me vestir como era "necessário" para poder entrar nas festas dos jovens ricos do bairro vizinho, para ser alguém, para ser desejado. Me lembro da minha obrigação de junto com meu irmão cuidar da casa e de ir bem na escola, sem que ela se interessasse mais de perto pelo que comigo acontecia, lá dentro ou fora. Havia um sentimento não nomeado e não partilhado de orfandade, de humilhação.

Ela não gosta de lembrar de seus dissabores paulistanos, não gosta de muitos aspectos de seu passado, muitas vezes a vi falando com acentuado ressentimento dos lugares de onde veio. Mas há gratidão também, pelos amigos que tantas vezes a ajudaram, ensinaram como viver aqui, tornaram possível crescer.

Não há uma única história feliz da vida dela com meu pai. Dele só me disse da bebida - a frequente frase com a qual a família o define: "era inteligente, boa pessoa, mas bebia". Que achava que iria fazê-lo parar de beber, mas não conseguiu. E, mesmo após tantos anos, há pouco tempo atrás falou ainda com raiva dele para minha mulher, por causa da lembrança do ciúme violento e injustificado que ele sentia.

O que posso dizer sobre minha história com meu irmão Cláudio foi que ele, até então o filho caçula e o único que vivia com minha mãe (os outros dois foram criados por uma tia paterna), foi destronado pelo novo bebê e teve que admitir um padrasto na pior acepção, pois meu pai fez prevalecer o filho de sangue sobre o enteado: parecia dar toda sua atenção para mim, presentear-me, desrespeitar os espaços e brinquedos de meu irmão em meu favor. Irmão que nunca, nesse período e muito depois, foi amigo. Brigávamos muito, ele se aproveitava de seu porte físico e depois da ausência de meu meu pai para me bater; me ofendia, ridicularizava; eu revidava como podia ou me queixava a minha mãe quando ela chegava de noite do trabalho, quase sempre sem condição de resolver pacificamente a situação dos filhos: se ficasse nervosa nos batia, cobrava a ordem na casa e o bom desempenho na escola. Duas crianças se havendo com preocupações adultas, crescendo juntas, sem acordo, cuidando de si mesmas e assumindo as tarefas da casa. $\mathrm{O}$ 
que pode ter representado o nascimento de virtudes e privações.

Anos depois, pergunto a ele sobre o que lembra de meu pai. Quando o Cláudio dá uma resposta benévola, por demais geral - "Ele era legal, boa gente" - tudo indica que ele estava muito mais preocupado comigo que considerar realmente o que foi a experiência com meu pai, e tudo indica que foi uma experiência insignificante. Meu pai apareceu fazendo muita discriminação entre o filho e o enteado e uma criança de seis ou sete anos fica muito ameaçada pelo nascimento de um irmão e um padrasto. Era legal porque não fazia mal? Era legal por quê? Meu pai não foi bom padrasto para ele.

Minha mãe é muito amorosa mas obrigada ao pragmatismo, o que enxuga a ternura, fora o fato de ter que ficar longe dos filhos - isso pode ter empobrecido o contato. A falta dela se cura quando penso nos sacrifícios que fez para que eu pudesse comer algo gostoso, para que pudesse crescer. As privações relacionadas à minha mãe não estão ligadas à capacidade dela de amar tanto quanto às circunstâncias de dura necessidade. É como se eu tivesse a experiência do amor e do zelo dela mas eu tivesse que passar a infância me contentando com alguns sinais disso e não com sinais cotidianos, embora estes não sejam raros. A memória dela, a que tenho e a memória que minha mãe tem de si, podem estar prejudicadas por causa da situação prática. Ecléa Bosi contrasta a memória dos velhos com os adultos ocupados: os últimos não têm tempo pra lembrar, não têm aquele estado de ócio sagrado, amigo da memória, que escava os tesouros do passado.

Minha mãe traz uma memória negativa de um homem que não foi companheiro, que se perdia em ciúmes arbitrários, subjetivos. Mas ela está por trás de tudo que ficou intacto e cresceu em mim. Sem exageros: o que se diz não leva em consideração essa relativa parcimônia dela em cuidar das coisas do espírito, a ternura ficou com sinais discretos. E eu gostaria de ter entendido isso, para estimar que eu também tinha mãe, coisa que só descubro retroativamante, agora, lembrando, narrando a alguém o que na infância não devia ser evidente pra uma criança com poucos recursos: saber que não tinha pai, mas tinha mãe. Há uma restauração aí (o sentimento de não ter tido mãe virou um ressentimento baseado numa compreensão lacunar dela que só foi se completar com o 
tempo: eu precisava me reconciliar com um passado que ela se recusava a visitar). Há uma compreensão lacunar dela que só depois conquistei e que confirma o apoio que eu tinha nela e que estava por trás das coisas que fui capaz. Ela ficou muito sozinha, longe da gente, pessoa a quem foi dado muito pouco tempo para aproveitar a convivência com os filhos. Do mesmo modo como pode-se dizer que esteve longe dos filhos, estava porém presente na casa que mantínhamos bela e hospitaleira - transicionalidade: a casa estava no lugar da mãe.

O Japão, o que ele simboliza como um bem de outra ordem que não apenas a econômica, está aí. Perto da mãe. Está na casa da aliança, por exemplo. A memória põe ênfase no espaço, da casa e da rua. Lembro das constelações familiares evocando as casas, e quando se trata dessa casa aparece um episódio de beleza compartilhada. É onde pude me espraiar. Nem parece que minha mãe trabalhava tanto nessa época como em outras. Essa casa abrigou a memória do contato com a mãe, que deveria ser tão esporádico e frequente quanto sempre foi. E uma mãe de um filho que cresceu: a mãe que procurava ensinar a dividir e não comer tudo compreende que o encanto fica mais completo com os docinhos e me deixa comer - porque aí eu não estou comendo o doce dos outros.

A memória de raiz está associada a mãe e ao irmão. O senso do enraizamento está ligado ao lado materno. O senso da raiz, hospitalidade, vínculo, aliança, é biograficamente informado em proximidade com o mãe e tudo isso é fraturado quanto ao pai. Faço um reencontro com meu pai a partir de uma herança que é materna, não paterna. Mesmo meu tio Chico, encontro significativo que ainda vou narrar, pode ser estimado a partir de referências que vinham da mãe, não do pai.

Nessa segunda casa a memória do irmão vem de outro jeito. Contrasta com a memória de falta de amizade entre nós - atravessados que estávamos por rivalidades e inseguranças características de irmão mais velho e irmão mais novo: aparece o episódio do trem. Essa casa é a casa da aliança - do arco-íris que é o símbolo bíblico da aliança. A casa ajudou a enxergar e ver que eu tinha uma mãe. A memória antes está muito incerta, na primeiríssima infância - a mãe está lá, mas aqui está mais nítido. Eu também estava 
mais crescido, maduro, com mais recursos: posso perceber a passagem para uma casa mais hospitaleira que apóia melhor o sentimento de vínculo, de raiz. No lado materno encontrei holding, sustentação, inclusive quando resolvi viajar.

Falando da primeira casa, onde ainda vivi com meu pai, falei de meu irmão numa situação de instabilidade emocional dificultando a amizade entre nós. Na segunda casa, há traços de amizade. Gosto da companhia do irmão criador de um trem fantasma no quartinho dos fundos, que me fez ser o primeiro convidado. Meus traços japoneses são empenhados como coisa negativa no conflito com ele - restaurar minha "japonidade" é mais do que aquilo que já é muito, que é restaurar meu vínculo com tradições, práticas e pessoas japonesas familiares ou não, mas é também restauração pura e simples de minha dignidade, da aliança com o outro, do entrar numa relação de companheirismo com o irmão. O que pode ser dito é que a recuperação da minha raiz japonesa não é recuperação só da raiz japonesa, o que já é muito - é recuperação da raiz, porque me devolve também ao que não é japonês em mim e em minha história.

\section{Dialética das raízes nipo-brasileiras}

Se é verdade que o apreço pelos estudos tem uma raiz, parece que a geração desse apreço se faz pelo lado da mãe, pelo lado de uma raiz brasileira, no episódio do primeiro dia de escola. Quando depois - o estudo é valor japonês - o meu apreço pelo estudo vem, não é japonês simplesmente. Ele parece ser originariamente brasileiro e se confirma de um modo japonês. Um certo valor japonês vem encontrar uma preparação e uma realização fora da ascendência japonesa. O que acontece é que em grande medida meu contato cada vez mais aprofundado com as raízes japonesas veio, em grande medida, reforçar certos traços de raiz que não dependeram primariamente de qualquer consideração sobre a minha condição como um nipo-descendente.

Fica muito forte a associação entre o primeiro sentido de raiz e a mãe e dessa maneira o lado brasileiro da minha ascendência. Vai ser de um modo peculiar e muito particular que vou conseguir apurar o que o Japão me traz. A pergunta é: porque será que o Japão assume uma importância destacada na busca de raiz e quase uma importância exagerada à luz das revelações que o depoimento até aqui trás. Os valores que trago em 
mim e que são fortes em meu caráter são mesmo o de um brasileiro que reclama sua dignidade entre outro grupo de que faz parte.

A estimativa da raiz não parece ter dependido do contato com a raiz japonesa que ficou prejudicado. Não sou um desenraizado que precisava de raízes japonesas para cair no senso da raiz: tive experiências que foram mais ou menos enraizadoras mas que deixaram sinais da experiência de uma raiz - e isso me tornou capaz de estimar a raiz ancestral distante - o contato com o pai interrompido precocemente. Eu já estava sensibilizado pra experiência de raízes, o que me colocou em boa disposição pra que um dia me sentir no desejo de ser devolvido à ascendência japonesa.

Zeca me conta durante a entrevista que Ecléa Bosi lhe dizia por que é que Paulo Freire - onde quer que tenha ido - frutificou seu trabalho: porque tinha uma raiz em Pernambuco e tudo isso representou o meio pelo qual se inaugurou uma participação firme no mundo - ativa, real e natural. Foi por esse meio que inaugurou uma relação muito importante e com fruto através de pessoas que guardavam tesouros do passado e pressentimentos do futuro. Porque havia uma experiência originária da raiz é que ele, noutras partes do mundo, teria encontrado também um lugar. O senso das raízes próprias prepara a gente para a apreciação das raízes alheias e a apreciação das raízes alheias prepara a gente para a apreciação de nossas próprias raízes - dialética que Simone Weil menciona: as influências externas devem contribuir pra tornar a vida daquele que as recebe mais intensa. Incrementam o sentimento da própria raiz e, então, a troca se faz de um jeito que não é violador, intrusivo, desequilibrado - duas culturas que se encontram não como presa e caça e aí valem uma para outra como uma revelação do existir entre homens. Cada uma vale pra outra como revelação de si própria e como revelação pra outra do que a outra cultura é. O encontro com o Japão revelou-me o tesouro das raízes que já carregava em mim.

A ênfase nas raízes maternas não é para desvalorizar o contato com o mundo japonês. Em toda caso há algo que parece manifestar-se nesses termos: houve um certo impulso pro Japão provocado também por um enganoso sentimento do passado, como se eu fosse demais violado da experiência de enraizamento - a falta de história no lado materno - e não fui. Mas houve certos momentos traumáticos que podem ter sido 
geradores de um sentimento que me fazia guardar o passado de modo relativamente injusto. Por exemplo: minha mãe foi retirada do contato bastante comigo na infância por força da classe, do trabalho, mas ao mesmo tempo está associada a muito do que fui capaz de viver como uma raiz. É claro que isso dependeu também de mim mas, no que dependeu dela, ela procurou estar ali, provendo casa, luvas, escola: experiências marcantes e geradoras de um sentimento de raiz.

A despeito disso, por exemplo, o fato de meu contato com ela ser um contato interrompido diariamente em razão do trabalho, contato esgarçado, feito de ciclos de mais intensidade e breves quando ela volta do trabalho e períodos de baixa intensidade de contato - isso deixou uma marca, uma certa tristeza, uma certa privação amarga. Mas pode ser que essa marca relacionada à mãe, essa amargura sem consciência desses detalhes todos tenha crescido desmedidamente, imaginando que eu precisasse começar tudo de novo a respeito da raiz, como se a raiz fosse uma experiência no futuro e não no passado. Pode ter havido algum tipo de confusão a esse respeito. Certos sentimentos amargos agravaram o sentimento de desenraizamento - mas felizmente houve experiências de enraizamento que se não tivessem havido não me permitiriam lembrar agora, porque o enraizamento é uma condição pra memória.

Meu interesse pelo Japão muitas vezes soou exagerado muitas vezes, nesses últimos anos, até mesmo para mim. Tenho de fato a sensação de que o enraizamento é algo que para mim está no futuro e não no passado.

Fui privado de passado. Encontros, narrativas familiares, experiências pessoais com coisas do Japão - e do nordeste ( a não ser a confirmação de que ser nordestino era um constrangimento, um motivo de vergonha para uma família que vivia em São Paulo).

$\mathrm{E}$ as pessoas me mostravam que eu era, afinal, japonês. Infância, adolescência, faculdade - e eu não sabia o que é! Quando eu descubro o Japão e descubro belezas e me reconheço, sinto algo familiar - como faço parte disso? Quando vi o Fuji-san algo em mim dizia que aquilo é familiar, que eu conheço aquilo de algum jeito. Assim é no kendo, na língua japonesa, no taiko... O Japão talvez tenha aparecido como cura pra muitas dores que o cuidado materno não foi suficiente pra curar: o desenraizamento da pobreza, da diferença de classes, da humilhação, do desemprego. 
O passado não é de absoluta carência e privação: é de privação associada ao lado paterno da minha personalidade. Quando penso no lado materno, a privação também existe e torna ainda mais urgente uma raiz e mais intenso o sentimento e depois a compreensão da importância de uma raiz na vida da gente - do passado, da herança, das narrativas que nos localizam. Mas felizmente houve experiências de enraizamento que ficaram guardadas como muito preciosas. Estimei a falta de narrativas sobre a minhas origens (japonesa e brasileira), por exemplo, porque havia um senso disso.

Vem do lado materno uma experiência de enraizamento que é importante e uma forte experiência de desenraizamento vivido pelas pessoas do lado materno: havia um sofrimento em minha mãe por ser nordestina. Havia, por sermos nordestinos, em meus irmãos, uma negação do próprio passado, da própria origem. Não era desinteresse, era não querer saber de ser nordestino - eles nascidos lá e filhos de pai e mãe nordestinos. Meus irmão nunca gostaram de dizer pros amigos que são de lá, piadinhas, terem vergonha dos discos de Luiz Gonzaga nos domingos, sem abertura para a apreciação de nossa herança - nordeste estava sempre associado a alguma coisa ridícula, atrasada, burra, jeca. Não era algo para se conhecer, compreender, gostar autentica e publicamente. O Walter fazia brincadeiras com minha mãe que muitos anos depois eu descobri que ela não gostava, sentia-se humilhada com isso: falar com sotaque nordestino, falar debochadamente de comportamentos de lá.

Ela não sentia vergonha a ponto de negar sua própria origem - eu vejo até hoje julgamentos duros, precipitados, avaliações pouco justas generalizadas demais sobre a cultura nordestina. Porém às vezes condenando o que de fato representou sofrimentos e deveria ser diferente: não ter podido estudar por ser mulher, a rigidez da educação religiosa, os pais que batiam nos filhos... Cuidar da casa, criar e educar os filhos, o jeito de se vestir são generalizadamente coisas atrasadas pra ela: em São Paulo é que estão as coisas boas, que são progresso humano. A vida rural nordestina é atraso, São Paulo urbana e industrial representa progresso. Meu avô - a pessoa a quem ela era a mais ligada por ser menos religioso - não fazia questão que mulher nenhuma estudasse, só o filho minha avó insistiu mas não persistiu na escola para as filhas. E Dona Santa era, por outro lado, insistente e persistente, exigentíssima, em transmitir para as filhas a educação que 
acreditava ser a boa para a mulher: aprender a costurar, a cozinhar, cuidar de uma casa e ser católica. Minha mãe sempre tentou escapar dessas exigências e impedimentos. Seu primeiro casamento foi ainda marcado por essa mesma condição submetida ao machismo nordestino: foi quando terminou - para que tudo isso terminasse - é que veio para São Paulo, atrás de uma nova vida.

Pra mim, o que fica é essa marca, essa pergunta: por que é que a gente não entende isso juntos? Por que aconteceu, por que acontece isso? Se eu experimentei algum desenraizamento aqui em São Paulo - não por ser nordestino, mas por ser menino pobre convivendo com os jovens de Higienópolis - por que em casa eu reconhecia que as pessoas sofriam o mesmo, tentando dar o sentido que pudessem para suas amarguras, e porque a gente não reconhecia isso juntos, tematizava, enfrentava, compreendia isso juntos? Por que não havia histórias, narrativas, por que ninguém se propunha a lembrar? Pensar a própria história, a própria vida?

Existe um ingrediente no meu apreço pelas revelações de mundo de todas as formas - ao vivo e por livros, pela mediação de professores e mestres - que se não é o determinante suficiente é muito significativo: é o amor por minha mãe. Isso me protegeu da vergonha da minha condição e me levou ao apreço pela condição e até a uma estimativa do que era necessário para tornar minha condição ainda mais afirmada de filho de nordestina e filho de japonês. Existe esse ingrediente amoroso muito forte. Tanto é que a confissão do amor da mãe por mim (o episódio dos sanduíches) engasgo e fíco com vontade de não registrar, tal a intimidade disso. Mas precisa ser gravado!. Não sabemos se é o ingrediente decisivo, mas é um dos ingredientes decisivos do fato de eu ter vivido uma condição que faz girar a condição vivida pelos irmão e em certa medida pela própria mãe, que é de um desprezo pelo passado, pela ascendência, pela tradição, pela origem que não fez nenhum bem aos irmãos e à mãe e não fazia bem a mim, só que eu me levantei contra esse mal do desprezo, da vergonha, da humilhação e do desenraizamento.

Minha mãe talvez também tivesse aprendido a estimar melhor a raiz nordestina se ela tivesse vivido com os filhos no nordeste, porque amando e vivendo o amor aos filhos lá, ela encontraria mais carona pra amar o nordeste, uma vez que os filhos são 
nordestinos. Brincadeira do Zeca comigo, durante o depoimento: eu atrapalhei porque a faço amar São Paulo... Penso por exemplo em minha tia Glória e minha prima Valquíria nordestinas com toda a honra.

É importante essa dialética: perceber que do lado da mãe conta a raiz e conta a experiência de privação; do lado do pai conta muita privação - que, depois, o contato com parentes, algum contato com ele e o contato com o Japão quando estive lá ajudaram a temperar, corrigir, curar.

E, se há essa ênfase no que pode parecer estritamente biográfico, é porque trata-se aqui de pai e mãe duplamente imigrantes, a quem abre-se igualmente o mesmo destino, a mesma marca em suas sensibilidades: o estatuto de cidadãos subalternos, expostos ao trabalho reificado e ao desenraizamento, impedidos de permanecerem em seus lugares de escolha e de coração. Uma questão transgeracional se estabelceu, engima anterior a mim e também anterior a eles, que nos marca a todos.

\section{O “japonesinho" visto pelos outros}

Quando busco considerar quando é que começou se formar minha consciência de brasileiro descendente de japoneses, o que ocorre? Há o contato curto com o pai, os mimos da mãe, coisas derivadas dos contatos com o padrasto, com os irmãos, coisas da escola e assim segue, numa sucessão de experiências na escola, no trabalho, na cidade. $\mathrm{O}$ que conseguimos apanhar daí?

Não tive apelidos que assinalassem isso em casa. Na escola me lembro da época em que eu e meu irmão estávamos na mesma escola e dos colegas dele espantados com nossa diferença de irmãos maternos. Ele ficava constrangido: por quê? Por ter um irmão japonês ou por ter um irmão de um segundo casamento da mãe? Eu não sabia.

Me lembro da terceira série e da fama de japonês, porque fui elogiado pela professora pelo boletim nota dez em todas as matérias: no final do primeiro semestre me elogiou e desafiou a manter as médias, no que acabei me engajando: no final do ano, 
novo elegio público porque tive um ano brilhante. Para ela era claro que meu desempenho era manifestação clara de minha ascendência, enquanto que para mim era o gosto de ser elogiado por um esforço pessoal, que nada devia a ninguém senão ao meu desejo de desempenhar bem uma tarefa, de receber o elogio de que tanto gostei na primeira vez, já que também gostava dela. Aí uma virtude minha ficou associada a minha raiz japonesa mas essa associação não era aceita totalmente porque eu não entendia o que é que ela significava - eu não achava que era isso: pra mim o que valia era chegar ao fim do ano com o boletim "perfeito", era manter o bom desempenho, merecer o elogio. Eu não me dava conta do que era ser japonês. Eu não tinha um interesse particular pelo Japão na infância, fora aquele de qualquer criança fã dos heróis de televisão japoneses como muitos de meus amigos eram, mas isso não era motivo de qualquer orgulho particular ligado ao meu "ser" japonês.

Meu padrasto, Walter, apareceu em minha vida por volta dos meus cinco, seis anos de idade. Era muito carinhoso comigo nessa época e havia algo de que eu gostava muito nele: era ele quem me ensinava sobre o mundo, respondia minhas perguntas, explicava como funcionava o avião, como fazer mágicas, histórias dos lugares que visitávamos. Bom cozinheiro e nadador. Às vezes me chamava carinhosamente de japonês e se preocupava que eu soubesse coisas do Japão, embora não tivesse me ensinado nada particularmente. Nascido em Mogi das Cruzes, me falava como são os japoneses: esforçados, inteligentes, estudiosos - teve amigos japoneses com quem aprendeu e soube admirar.

Nos escoteiros, que frequentei por alugns anos, eu era o "Toshi" (Toshiba) - no começo não gostei, mas aprendi a gostar, porque o apelido não me impediu de fazer amigos e eles nunca me fixaram nesse lugar. Mas mas me lembro do um menino com quem a história não foi a mesma: mestiço, como eu, mas de ascendência nipônica e africana. Os outros meninos anunciavam seu apelido com certa maldade, escárnio: "japonês preto". Foi perseguido, alvo de chacotas constantes. Tentei defendê-lo, dissuadir meus colegas, acolher, ajudar a assimilar a raiva conversando sobre minha própria experiência - de uma certa humilhação no início para o esquecimento do estigma e a amizade do grupo. Não gostava da brincadeira que faziam com ele: a amizade que 
conquistei não apagara o amargor inicial do apelido humilhante. Mas não consegui: o grupo não esquecia, ele passou um mês no grupo quase sem falar com ninguém e, depois, nunca mais apareceu.

Com cerca de nove anos fiz uma viagem ao nordeste, com minha mãe, que visitava sua terra natal depois de quase vinte anos migrante em São Paulo. Certa vez, na casa de alguém que visitávamos, uma senhora, impressionada com o menino japonês, começou a perguntar, discutir e insistir, me olhando como que diante de algo muito bizarro: porque é que eu não falava japonês, se afinal de contas eu parecia um? Nada que eu dizia - ou depois, qualquer outro adulto que veio em meu auxílio, irritado que eu já estava - pôde esclarecê-la: eu era de outra "raça", tinha que falar feito outra raça. Minha mãe percebeu o incômodo e fui embora irritado do lugar. Porém, na mesma viagem, encontramos um rapaz para quem - absoluto contraste - eu era a criança mais admirável que ele, admirador da cultura japonesa, já conhecera: para mim, apenas porque tentava responder, com o bom senso que me era possível, a suas perguntas: quais minhas opiniões sobre... sobre o quê, mesmo? Não me lembro, só me lembro que, para ele, eu tinha uma maturidade que ele havia visto até então em criança nenhuma e, de novo, o motivo era minha ascendência. Por ser japonês - para minha incompreensão - entre o débil e o sábio, fui personagens opostos!! Paradoxo "zen”...

A convivência com nipo-descendentes passou a ser maior na Escola Técnica Federal de São Paulo, onde ingressei com quatorze anos. Havia muitos jovens, alunos nipo-descendentes lá. Havia a turma que se auto-intitulava nihonjin (japonês) - os que sabiam falar a língua, tinham acesso à cultura de massa japonesa e coisas que tais, além de alimentarem certo desprezo pelo Brasil e pelos brasileiros. Para eles, o Japão rico e tecnológico dava provas claras de ser superior ao Brasil - por extenção, a superioridade se extendia a seus respectivos povos. Pode-se daí imaginar os preconceitos que se desfiavam sobre a situação do povo brasileiro. Eram solidários entre si em todas as atividades (até se colassem numa prova) e segregavam mais ou menos discretamente os que, como eu, foram colocados entre os gaijin (estrangeiros) porque não participavam disso; eu me declarava um garoto brasileiro - não conhecia o Japão, não falava a língua, 
não me interessava por cultura pop japonesa e achava essa atitude de grupo sectária, um tanto ridícula. O que me fez afastar-me mais da "colônia". Era o Japão "superior" ao Brasil.

Fui o único amigo japonês do chinês Chun, que bateu num garoto japonês na sua primeira semana de aula, e manteve-se hostil a todos eles até boa parte do curso, alimentado por velhos ódios chineses aos japoneses - chegou aqui aos sete anos de idade, cheio de histórias terríveis dos períodos de guerra entre os dois países. Ele me considerava uma exceção entre uma "raça" que não "merecia consideração".

Mas ainda assim o Japão era exterior. Considerando essas lembranças, pareceria artificial encontrar na infância e juventude qualquer afeição precoce pelo Japão, pelas raízes japonesas, pelas tradições e pelos japoneses. Existo orientado sobre mim mesmo sobretudo como um brasileiro, até como gaijin. Não participei de grupos sectários que se comportavam como se contassem mais do que os outros - até me associei a um "inimigo" deles e minha turma os ridicularizava. Os esforços de minha mãe e padrasto são coisas queridas mas sem efeito significativo na ocasião: cresci orientado à respeito de minha identidade como a identidade de um brasileiro. A senhora que me estranha irrita, o rapaz apesar do encanto não me fez sentir-me japonês - as associações pareciam exteriores. O único gancho mais significativo é o do pai japonês mas que não me apresentou ativamente o Japão: não falava japonês, mantinha relação de conflito com o próprio pai. Até aqui a condição japonesa parece contar como algo consideravelmente exterior, ligada a um fenótipo, a uma aparência física e nada que tivesse ingrediente espiritual significativo. Isso chama a atenção e deixa na espera esse lado da minha origem. Até aqui não há sinais de nenhum impulso importante na direção do Japão e dos japoneses, da cultura japonesa.

Onde se formou uma consciência de si ou a busca de uma consciência de si como um descendente de japoneses? Até aqui tudo está, em relação a esse aspecto, discreto ou até insignificante. Há uma composição de valores e experiências num sentido que não parece associado à minha ascendência japonesa.

\section{Japão? Japonês?}


Talvez as coisas comecem a mudar por causa de algumas pessoas. Uma delas é dona Candelária, minha professora de literatura. Certa vez, refletindo sobre um poema de Gonçalves Dias, ("Marabá", mameluca, nem índia nem portuguesa, e por isso sem lugar no Brasil que começava a tomar forma), questionou-nos: cada um, um dia, olha-se no espelho e se pergunta quem é, que história o formou. Éramos, eu e alguns amigos, muito próximos dela, que parecia nos endereçar sua questão. Sua análise do poema sobre a mestiça sem raízes e suas questões, tão pessoalmente dirigidas, nunca foram esquecidas. Aquelas aulas que nos aproximavam tanto da história de nosso país, sua formação e sentido, através de personagens singulares, a literatura que descobríamos juntos, apresentou-se de repente dizendo que era de nós que ela falava.

Meu irmão Giancarlo me apresentou o kung fu, arte marcial chinesa donde deravaram as artes guerreiras nipônicas. Me ensinou e levou para os treinos. Gostei demais. Anos depois, quando pude bancar meus treinamentos, cheguei até a auxiliar meu mestre nas aulas, coordenar equipes, participar de campeonatos. Mas, na época, aprendi com meu irmão que nas lutas os guerreiros chineses e japoneses descobriram outros dons das práticas marciais, para além do uso defensivo e dos benefícios atléticos: o crescimento espiritual nas práticas. Descobri através dele a meditação zen, que passei a praticar assiduamente, livros sobre o oriente, que descobri junto com o Japão como bens culturais, como experiências humanas singulares.

São dois brasileiros e meu interesse inaugural começa por uma razão que não é automática: não é por ser filho de japonês, não é por contato necessário com tradição japonesa nenhuma - quase que lembra o tipo de interesse que pode ser despertado num não-descendente de japoneses. Mas aí o fato de ser descendente assume uma outra condição, outro registro para mim: meu interesse pela luta que se desdobra em um interesse pelo oriente; a professora que me pede considerar se aquela dupla condição de Marabá, mestiça, de dupla inospitalidade, era uma condição sentida por mim - pediu que eu considerasse mais frontalmente isso: se o fato de ser um brasileiro descendente de japonês tinha tido implicações no meu contato com os grupos e com o outro, ou não. Ela me tirou de uma certa inconsciência a respeito desse problema. 
Mas é difícil decidir se o que ela diz é significativo em si mesmo ou se tornou significativo porque de certo modo ressoou em alguma experiência minha de não integração. Ao que parece a integração era problemática quando contava do lado dos grupos japoneses. $\mathrm{Na}$ Federal eu ficava fora porque era posto fora e nem queria me incluir num grupo assim. Em casa, a essa altura, vivíamos os quatro filhos, a mãe e o padrasto juntos, mas vivíamos cada um preocupado com seu próprio projeto de vida, especialmente a profissional: meus irmãos já trabalhavam e frequentavam a universidade, minha mãe seguia sua rotina de administração da casa e de trabalho fora. $\mathrm{O}$ desejo e a necessidade de superar a difícil condição econômica e a dura rotina de cada um prejudicavam nossa convivência: não havia tempo para o entendimento das questões que nos mobilizavam. Era uma família endurecida pelos rigores da vida, organizada com pouco espaço para a amizade, para uma convivência que superasse o apoio econômico mútuo entre os membros. E para o único membro ainda não pressionado pelas exigências do mundo do trabalho, que se sentia com pouca voz naquele núcleo - onde respeito era algo a ser conquistado - aquilo tudo parecia árido, enigmático, frio. Parece contar também aí uma não integração que me sensibilizou e tornou-me bons ouvidos para as questões que a professora me convidava a responder.

Conversando com a Paula, amiga daqueles tempos de colegial:

“_Sabe, estive pensando, eu tenho uns primos no Japão...

Ah, não me diga que você está pensando em ir trabalhar no Japão só para ganhar dinheiro!

_ Não, não. Eu não faria isso...” 
Mas, na verdade, apesar de não ter dito mais nada para a amiga, eu já sentia, naquela época, que meu futuro nunca seria livre das dificuldades econômicas que eu já vivia em casa e das preocupações e distâncias entre a família que elas, em parte, causavam. Apesar de também achar a aventura dekassegui perigosa e sem sentido, concordando com minha parceira, o apelo, inegavelmente, estava lá: trabalhar, economizar, de volta poder comprar uma casa e ainda ter algum dinheiro para seguir a vida aqui com mais - ou mesmo com alguma! - segurança. Estudar, montar negócio próprio, o que fosse. O plano comum todo dekassegui.

Mas o Japão, seu significado "financeiro", assim apenas, soava pobre na alma. O que eu buscava estava em outro lugar. Havia encanto nascente pela experiência humana, pela novidade de seu pensamento e conduta, pela beleza japonesa, sua expressão: mas a porta de entrada era a mesma que eu já testemunhava aqui.

\section{Tio Chico}

Após a morte de meu pai, fui convidado para o casamento de meu primo paterno Edson, em Barra Mansa, estado do Rio. Minha tia Elza insistiu para que eu fosse e conhecesse meus outros tios. O tio Oscar, sempre frio e distante, vi outras vezes, mas foi meu único encontro com meu tio Chico. Dormimos na noite da festa na casa dele com a esposa brasileira, muito carinhosa e simpática. A casa estava cheia naquele dia (brasileiros e japoneses) e ele estava lá, mas eu não sabia que ele era o meu tio. Todas as senhoras calorosas comigo - algumas já sabiam que eu era filho de Shim, outras eram avisadas pela minha tia e se mostravam muito felizes de me conhecer pois haviam conhecido meu pai.

Tia Elza nos apresentou. "Olha, esse aqui é teu tio". "Olha, esse aqui é o Alexandre". "Ah, tudo bem?" disse, formal e quase indiferente, e eu formal e tímido do meu lado, pois me sentia deslocado naquele lugar e já não esperava muita hospitalidade e calor dos meus tios - dado meu contato com o tio Oscar. Sua frieza não foi igual, mas não me surpreeendeu: “As coisas devem ser assim na família...”, pensei. Ficou por isso mesmo, pelo menos naquele momento, com todos ocupados com a festa, aquela bagunça, aquela falação antes da cerimônia, todos se arrumando. 
Até que em determinado momento, talvez querendo me tirar da atitude discreta e calada que assumi naquele cenário (onde todos se ocupavam da festa) e reconhecendo a importância da minha presença entre familiares há tanto tempo distantes, minha tia voltase para os dois, acomodados perto um do outro mas sem conversar e diz: "Escuta, você não está conversando com ele, sabe quem é ele? É o filho do Shim! Ele é o teu sobrinho”.

A mudança em seu semblante e de sua atitude, seu espanto com o súbito entendimento da situação, com a descoberta, são inesquecíveis. "Mas você é filho do Shim!!! Nossa!! Alexandre, vem aqui...!". Ele pareceu se dar conta apenas ali de que eu era sobrinho dele, que era filho do irmão dele, Shim. A partir daí mudou tudo: quase não desgrudou de mim, queria saber tudo a meu respeito, me apresentava orgulhoso às pessoas, me mostrou a casa, me mostrou fotos... Me apresentava e algumas pessoas até achavam engraçado o fato de ter demorado para se dar conta de que eu era filho de seu irmão.

Aquele senhor com forte sotaque japonês me adotou naqueles dois dias: nos encontramos na hora do almoço, o casamento era no final da tarde, mas ele queria aproveitar cada minuto: "Você sabe japonês? Ah, tem que aprender" e pegou o livro de japonês pra me ensinar. Eu, pego de surpresa, tentava explicar que não havia aprendido nada ainda - e ele se admirava, reclamava com minha tia de ninguém ter me ensinado o nihongo, e se voltava carinhoso pra tentar me ensinar com sua velha cartilha. As pessoas até tentavam tirá-lo de perto por alguns instantes, pois percebiam que aquilo tudo estava me desnorteando um pouco. "Deixa o menino se arrumar pra festa!"; "Chico, vai se arrumar também!”. "Não! Deixa eu ensinar o menino! Ele tem que saber nihongo!” e só saiu de perto de mim meio contrariado. Me queria o tempo todo do lado dele. Gostei demais dele...

Ali, com ele, me senti em casa, naquela festa em que me sentia tão forasteiro. Sempre quis aprender kanjis, tentei mesmo aprender. Me mostrou fotos e me contava do quão amigo era do meu pai, quem ele era (inteligente, estudioso, alvo das maldades dos irmãos mais velhos de quem ele, Chico o defendia): a vida na lavoura, o filho que estudou, esforçado atravessando a pé o cafezal enlameado para ir pra escola. Foram horas de boa convivência, ao lado daquele senhor amoroso e saudoso de um Japão que nunca pôde visitar desde sua chegada ao Brasil, mas que fazia questão de me apresentar. Foi o 
único na família que realmente, ativamente me incentivou a conhecer e participar da cultura e das tradições japonesas. Me fazia experimentar comidas, me ensinava nomes... Com ele não era: "Você tem que saber porque você é japonês", que era como meu padrasto fazia. Meu tio era o que ensinava, e me mostrava: eu gostava ou não, mas era meu gosto. Rimos, pensamos, conversamos sobre aquilo tudo que ele queria me apresentar; em certos momentos, marejou os olhos - saudades da terra natal? Minhas as palavras de João Antônio: "Gostei. Como quem descobre uma maravilha gostei (...) Poesia naquelas coisas." Coisas minhas também.

Foi depois desse encontro que comecei a ouvir falar, pela tia Elza, do que depois foi chamado "movimento dekassegui". Conversava a respeito com amigos e achava um absurdo sair daqui para trabalhar num pais para ganhar muito dinheiro e voltar, na época. Eu fiquei; meu tio foi para o Japão, assim como meus primos, minha tia. Ele viveu lá até sua morte. Viveu seu retorno.

Ele tem dupla importância: uma relativamente à orfandade de pai - porque com ele volta meu pai representado por ele, que o amava - e ele mais do que meu pai se mostra ativamente desejoso de minha presença ao lado dele, de me trazer pra perto dele e pra perto dessa raiz e ambiente humano paterno com uma energia que eu não encontrei em meu pai. A expectativa inicial que tenho dos homens da família japonesa é a de que vão me abordar à distância, com indiferença ou no máximo com uma proximidade educada, mas sem energia ou continuidade. E meu tio me trás pra perto, me ensina japonês, me hospeda, quer me ver em Barra Mansa - uma experiência de amor ativo que tempera o fato de eu ser filho de um pai de amor que pouco ou nada age. E meu tio ainda assinala uma figura ativa na pessoa de meu pai, coisa que eu mesmo não experimentei: Shim aparece alcançando a escola, através da lama do cafezal... Tio Chico torna o esboço do meu pai um desenho completo, que pude amar como meu tio amava. Ele me devolve para uma figura de pai atraente, capaz de cuidado ativo, instrução, capaz de trazer o Japão até o filho, suscitar o desejo do Japão. E soube me apresentar o Japão como mais ninguém na família: tia Elza, minha mãe e o padrasto, meu irmão Gian. Além dos bens culturais ele era um japonês que me amou como pai que ama filho. 
A experiência filial consistente que me entusiasmou: há muito amor por aquele homem e pelo mundo daquele homem. Há uma reparação localizada, limitada mas que assumiu uma figura de grande nitidez e importância na minha história, que restaura a figura do pai invalidado que desaparece e depois morre precocemente - tudo isso fica como que corrigido por esse contato com meu tio. Uma figura do pai resgatada. A partir daí posso novamente amar meu pai, amor agora temperado com ingredientes trazidos pelo tio - dele emprestei o pai que não tinha essas qualidades. É uma hora de virada com o pai e com o Japão.

Vivi uma orfandade de pai que me deixou necessariamente desligado da herança japonesa. Há já nele uma espécie de ruptura que em mim se aprofundou. Há uma ruptura que herdei e que meu pai aprofundou. Há o crescimento de um menino brasileiro, para quem a condição japonesa aparece sempre exteriormente, sempre lateralmente, sem "pegar". Ela começa a pegar quando pega por dentro e há duas vias pelas quais essa conquista interna de um sentimento de si como um japonês acontece: aquela conquista que vem pelo irmão e pela professora e aquela outra a pegada que vem pelo tio Chico. Aí parece realmente começar o impulso para o Japão.

O outro e a aliança amorosa são mediadores de nosso apreço por cultura, pelo passado. O tio é um mediador de meu interesse pelo Japão, pela cultura japonesa e pelos japoneses não só por causa do bem que há nisso tudo em si mesmo, mas porque ele é alguém saído dali, que vem falar comigo e me traz pra perto - há um amor que usufruí e que já existia entre ele e meu pai. Fui trazido pra dentro de um circuito que incluía meu pai: de proteção, hospitalidade, sentido, lugar.

Há uma recordação em geral negativa de meu pai em minha infância - esse caminho de restauração ou instauração de meu vínculo com o Japão e com os japoneses também valeu como um caminho de restauração de um vínculo com o pai.

A figura do pai foi recuperada num contexto de beleza, alegria e admiração. Meu tio me incluiu numa experiência limitada mas intensiva de paternidade feliz de que tomei parte como filho; meu tio - intensamente ligado ao Japão - inscreve um modelo de companhia paterna: entusiasmo e apreço pelo filho/sobrinho e entusiasmo ligado à tarefa de transmissão/apresentação da cultura japonesa. Sou visitado por alguém que contra 
tudo de traumático me põe numa experiência feliz de filiação que eu gostaria de viver freqüentemente com meu pai caso tudo fosse diferente.

A perseguição da raiz é perseguição do pai. Meu pai vai admitir um retrato - que não é um juízo, há muita coisa enigmática a respeito dele - de memórias muito tristes que são depois restauradas, me deixar com mais pai que antes.

Meu padrasto representa um pai mas meu tio mais ainda: era pai e pai japonês. Como as coisas com Shim não correram bem fiquei sem pai nem Japão, sem raízes. O Walter não seria capaz de proporcionar elementos de raiz japonesa, só de pai, apesar de ter tentado. Meu tio fez mais do que meu pai poderia ter feito se levarmos em conta a relação de um e outro com a tradição japonesa. Tio Chico teria sido importante mesmo que meu pai estivesse comigo - que com sua briga com o próprio pai e a tradição, não teria me proporcionado essa ponte, esse trânsito. Aí também meu tio teria desempenhado um papel. A gente tira muito de pouco: um encontro com um tio pode curar uma história inteira de trauma com um pai.

Amor de meu tio não foi o bastante pra salvar meu pai, mas foi talvez - apesar de muito incipiente - bastante pra minha salvação, pois ele marcou a matriz de um impulso pra minha consciência de mim mesmo como um descendente de japoneses, consolidando interesses que independente da família foram surgindo entre eu e o Japão e aí oferecendo condições pra atender a demanda feita pela professora: olhe-se no espelho, considere que você é em alguma medida nipo-descendente e procure responder o que isso significou e significa pra você - o mesmo que pra Marabá? Outra coisa? O que significou pra ela? Você conhece o drama que é dela? Que drama você conhece? Há um drama conhecido? Qual exatamente?

Meu trabalho diz respeito não só à condição dekassegui mas também à experiência das raízes e do impulso para as raízes, desejo de raízes. O que disse até aqui traz uma hipótese, talvez uma tese: seria de se esperar, eu sendo filho de um nipodescendente - por uma razão automática, que facilmente poderia se exprimir como uma razão natural - fosse devotado ao Japão e às tradições japonesas, às raízes nipônicas. Mas tudo indica que as raízes não se impõe como objeto de desejo por si mesmas - embora tudo que é ingrediente de uma raiz, idioma, objetos, lugares abrangendo cidades, países, 
um certo ambiente de natureza - exerça uma atração. Eu vivi uma atração pelo Japão que muitas vezes acontece independentemente de minha ascendência. As raízes não parecem ter uma força tal que as fizesse responder por si mesmas pelo desejo do Japão: o desejo do Japão só parece se perfazer quando as raízes entram numa esfera de apresentação delas mesmas, ou seja: sem mediadores humanos aplicados na apresentação do passado ao jovem e à criança, o desejo do Japão não parece suficientemente formado.

É notável que o desejo pelo Japão assume uma característica particular justamente quando vão contar figuras como o meu tio Chico. O pai nascido no Brasil por razões que o depoimento convida a pensar quais sejam - uma pessoa que trazia traços de um certo desenraizamento, que parece ter sofrido algum tipo de rebaixamento ou pressão por parte dos irmão, que incorreu no alcoolismo e outras coisas - não parece ter sido o agente decisivo do meu impulso, o agente decisivo de uma composição em minha vida de um grande interesse por escavar e pesquisar minhas heranças japonesas. É claro que ele é parte disso, mas não é o agente que ativamente apoiou e promoveu esse impulso. Outras pessoas parecem ter contado muito mais do que ele - minha tia, meu tio, apesar do pouco contato. O pouco contato mostra o quanto a figura de um mediador é decisiva e de alta qualidade mais que quantidade. Tive mais contato com meu pai mas o contato com meu tio é que foi determinante do meu sentimento de ser integrante de um grupo japonês

O impulso para as raízes envolve de um lado uma força de atração que vem das coisas mesmas ingredientes da raiz; mas de um outro lado o impulso parece não se perfazer se não contar com um mediador humano capaz de realizar aquilo que a psicanálise winnicottiana se chama apresentação de objeto. Sem um apresentador, as raízes parecem que não são capazes de suscitar um impulso que seja suficiente. Ou digamos que o impulso que as raízes, sem um apresentador, são capazes de suscitar é relativamente fraco e é geral: age sobre um nipo-descendente como age sobre pessoas que não tenham liames com o Japão por parentesco. E mesmo nesse caso das pessoas sem parentesco tudo indica que a figura de um mediador conta. As vezes em que o Japão me interessou independente da minha condição de filho de um issei houve um apresentador: meu irmão, por exemplo. Em que sentido, que medida o Gian e dona Candelária estão na mesma condição em meu tio Chico está? Como apresentadores eles supõe meu parentesco com a cultura japonesa - “está na cara”. Mas não estão, como o tio Chico, em 
linha direta ligados a mim por parentesco e extremamente afeiçoados às coisas do Japão é evidente o desejo dele de me iniciar numa série de experiências que guardam dívidas com as coisas do Japão, com os japoneses. Eles se aproximam, como apresentadores, do tio, mas no tio fica evidente a figura de um apresentador japonês do Japão. Que meu pai não foi: foi nipo-descendente mas não foi apresentador. Sou filho de um issei mas o impulso não veio automaticamente - o impulso não é automático, não é natural (no sentido em que seria alheio às trocas culturais, às trocas simbólicas e especialmente às trocas propriamente humanas); é um impulso natural no sentido em que, uma vez que essas trocas vinguem, o menino naturalmente se vê inclinado para as coisas do Japão. Há algo de natural mas dependente de uma modalidade de contato que é eminentemente humana, cheia de ingredientes profundos, simbólicos.

É um tipo de troca que depende de investimentos propriamente eróticos que com o tio são fortemente levantados. O impulso para as raízes não é uma coisa biológica, no sentido em que o biológico é posto como indiferente ao cultural e ao humano.

\section{Universidade}

Assim que entrei na USP fui para a moradia estudantil, porque perdi a casa materna: nesse mesmo período minha mãe foi morar em Caruaru, Pernambuco. Tentava vida nova em sua terra natal. Eu precisava, por isso, conseguir vaga no Crusp (Conjunto Residencial da USP), dividindo apartamento com meu irmão e dois colegas dele. O C109 era um apartamento escuro, com paredes de madeira, com um único quarto para todos. A pintura que fizemos ajudou mas não acabou com o aspecto sombrio, frio. A cozinha ficava fora do apartamento, no final de um corredor distante. A convivência entre os moradores não era próxima. Muitos se encontravam nos apartamentos por indicação do Coseas, órgão da reitoiria que fazia as seleções de moradores. Mudei de apartamento duas vezes, depois que meu irmão e seus amigos se formaram. Aquilo era um lugar de passagem, precária morada, onde não se esperava - e não se podia esperar - vínculos longos. No primeiro ano trabalhei na biblioteca da Faculdade de Educação, todas as noites. Depois disso vivi de bicos e/ou de economias de um dinheiro recebido de uma causa trabalhista de meu pai. 
Para me manter nos anos de universidade, trabalhei na Edusp e numa grande livraria da editora Ática, fui garçom nos finais de semana: bicos ou contratos temporários, exceção feita ao Ática, onde tinha carteira assinada como auxiliar de loja mas de onde saí para ir para o Japão. Trabalhei ainda para a editora Nobel, em feiras de livros, congressos na USP, e vivi períodos desempregado. De modo concreto me tornei sensível ao problema do desenraizamento no trabalho, e reencontrei a história, o destino familiar, as tristezas adolescentes.

Todo ano precisava passar por um processo de seleção na reitoria comprovando que minha renda não era suficiente para pagar um aluguel. Todo ano, portanto, a incerteza se poderia continuar ali. Era a experiência de todos: não ter casa, não ter onde morar, não gostar dali, não poder sair. E, na faculdade, conhecendo Simone Weil! Não ter onde morar, onde ter história, vivendo com pessoas com quem nem sempre você se dava bem, onde era preciso proteger objetos pessoais de furtos. Se você tivesse qualquer bem que pudesse ser índice de uma condição financeira melhor, você corria o risco de ser reprovado na avaliação sócio-econômica. Eram finais de semana solitários, sem convivência de bairro - para a rotineira compra de pães numa padaria, por exemplo, era preciso uma longuíssima caminhada para fora do campus! Havia certo preconceito também com os moradores, vindo de pessoas da faculdade. A comida em bandeja de aço feita e servida de modo industrial, com horários fixos. A sensação angustiante de tempo que não se completa e de não ter saído do lugar quando acaba o dia e você está de volta ao apartamento. A família longe, cuidando cada um de seu próprio destino. Um quadro de incerteza sobre um lugar próprio que se manteve ao longo de todo curso, e depois dele.

Ainda na universidade assiti à Comemoração dos 90 anos da imigração, com uma enorme queima de fogos no campus. Todos os moradores e muitos outros estudandes subiram para os terraços dos prédios do Crusp para ver. A cidade universitária estava repleta, lotada de carros, parecia que a cidade toda estava lá. Lembro da beleza e da admiração dos não descendentes pela festa, a maneira de nos olhar. Me orgulhei mas me dei conta que ainda era muito mais o menino brasileiro que está descobrindo o Japão, que um japonês. Tive vergonha de estar tão longe daquilo tudo. Eu era menos Toshi que o menino da Penha do conto de João Antônio, ou nem ele era. Da festa dos 90 anos 
participei assitindo, de longe e de fora como todos os outros naquele terraço - não tinha outra ligação com aquilo.

Do Instituto de Psicologia poderia falar de muitas pessoas e momentos, mas me limito a falar de três professores:

Me lembro das aulas da professora Ecléa Bosi: numa delas exibiu o filme Madadayo, de Akira Kurosawa. Eu conhecia pouco Kurosawa, e se conhecia, nunca senti impacto igual ao daquela ocasião. Retrata a história de um professor e sua relação com seus alunos no Japão do início do século XX. O filme me encantou e me lembro especialmente da relação da professora com o filme, que parecia comovida com aquele professor e seus alunos. Foi surpreendente e inesperado. Não me lembro dos meus colegas tão encantados assim com o filme, mas me senti próximo dela nesse dia, a professora que só fez se revelar mais importante ao longo de meu percurso na universidade.

Há outro episódio desse curso: o seminário que escolhi fazer com alguns colegas sobre a questão indígena. Me lembro que por causa desse seminário assisti a um documentário sobre um guerreiro indígena, dilacerado pela nudez da terra arrastada e exposta pelas máquinas dos posseiros, no lugar onde ele nasceu e cresceu. A falta de palavras dele, a responsabilidade que senti. Aulas da professora: como duas culturas podem encontrar-se como duas formas de existir e não como dominador e dominado? A professora começava a construir, em mim, um ponto de vista libertador sobre o sofrimento que era meu e de muitos. Como ela mesma diz, nosso destino é político.

$\mathrm{O}$ curso do professor Moura veio logo a seguir: na primeira aula, fiel às lições de Ecléa Bosi, nos falou de Simone Weil e do enraizamento. Ter uma raiz, começou a nos dizer, é participar real, ativa e naturalmente de uma comunidade; participação que seja real: concreta, contraditória, de corpo e alma; ativa: nunca sob o jugo de outras vontades, nunca passiva; e natural: espontânea, sem imposição; participação que se constrói na convivência livremente escolhida, em grupos que existam, lembrem e desejem juntos. $\mathrm{O}$ silêncio que se fez na classe enquanto falava era de uma atenção que nunca mais vi aquele grupo devotar a mais ninguém. Seu início hesitante virou segurança e coragem; as palavras cresceram, e de repente o que dizia parecia não vir apenas de si, mas da 
experiência mesma de enraizar-se - através do professor, algo de sagrado apresentava-se. Acho que sabíamos o quão vital e preciosa, decisiva porém rara, era a experiência de que falava. Valeu pelo curso todo e o professor que depois quis nos propôs experiências de trabalho proletário em que poderíamos, nós mesmos, descobrir do que falava, ganhou o respeito e a admiração de todos. Toda nossa amizade se seguiu dali. A graduação sem vida, abstrata e árida, que após um ano e meio cogitei em abandonar, nascia e florescia. Depois daquela aula decidi-me, enfim, pela Psicologia. E tenho certeza de que não foi apenas eu. O professor José Moura virou Zeca, ganhou monitores de disciplina, estudantes em seus grupos de estudos, orientandos, afilhados de formatura (e de vida), amigos.

De Gilberto Safra, esse extraordinário professor, como os outros dois sempre muitíssimo próximo daquilo de que fala, guardo uma especial lembrança, muito recente mas que tem o traço do que ele sempre nos oferece, do meu exame de qualificação: ao final de nosso encontro, após lições valiosíssimas de sua leitura sensível de meu trabalho, mostrei-lhe uma foto do episódio da praia com meu pai. Com seu jeito sereno e bem humorado, olhou por um instante, sorriu e disse: "Você viu? Você vê o que ele te ensinava aqui? Com sua resistência, te ensinava a tomar fôlego". Com seu comentário sobre meu pai e eu, como quem peneira ouro, nos ligou novamente.

Outra vez aparece alguém numa condição de apresentador do Japão ou dos japoneses pra mim. Outra vez não é alguém ligado por parentesco ao Japão e alguém que - como talvez no caso da dona Candelária e do Gian - alguém que convida muito naturalmente a um vínculo que excede um vínculo de pura consciência. No caso da professora Ecléa, por exemplo, há um contato comovido, uma experiência de aproximação interna com os japoneses - com japoneses, não “os" japoneses, uma vez que os personagens do filme são japoneses bem determinados e com um certo Japão: um que conhece aspectos da modernização industrial mas que guarda liames bem materiais e práticos com uma maneira japonesa antiga de ser. E o encontro das questões políticas que atravessam nossos sentimentos mais íntimos.

Nesse momento as questões que a psicologia me apresentava talvez começassem a ser assumidas como tarefa pessoal. A festa dos 90 anos me trouxe a lembrança da D. 
Candelária, de meu tio Chico. A história familiar se dispersava, quase não existia - não havia encontros e convivência, narrativas. A precariedade de morar no Crusp tornava presente a experiência constante em minha vida de estar em casas provisórias, de estar sempre em trânsito pressionados por questões econômicas. Mas o encontro com os professores e com os temas da Psicologia Social começaram a constituir um projeto que era ao mesmo tempo uma esperança de cura: passei a me apropriar de questões coletivas que eram ao mesmo tempo questões pessoais. Havia o sentimento forte aqui, enfim, de comunidade de destino: um engajamento autêntico a uma questão coletiva, não artificial e sem possibilidade de retorno a uma condição privilegiada de classe.

Meu pai não pôde me levar à admiração ao Japão, mas a gradual admiração pelo Japão e pelos japoneses que outros me apresentavam me levou à admiração pelo meu pai e por minha ascendência nipônica. Em meu caso esse desejo de retomar, restaurar e preencher lacunas à respeito de minha ligação com as coisas do Japão e com os japoneses valeu como algum remédio para minha orfandade paterna, para minha distância dos outros nipo-decendentes, familiares ou não. Era devolvido ao meu pai à medida em que era devolvido ao Japão e era devolvido ao Brasil também, à historia familar de migração/imigração. $\mathrm{O}$ caminho de restauração ou instauração de meu vínculo com o Japão também valeu como um caminho de restauração de um vínculo com meu pai e minha ascendência. E a possibilidade de comunicar-me com as fontes psicossociais, com as fontes políticas de sofrimentos familiares foi caminho de restauração de minhas raízes.

\section{Psicologia por quê?}

A opção pela psicologia, no fim do curso na Escola Técnica Federal, veio por uma questão militante: buscava não me contentar com uma posição um tanto voluntariosa de colegas do grêmio estudantil que achavam que a política e a luta por uma sociedade igualitária eram uma questão que, na época, entendia ser de mero convencimento - ou, se fracassávamos, de má intenção - dos outros; de que a "pobreza era injusta, que nosso país poderia estar muito melhor do que está e..." e bastava as pessoas saberem disso para engajar-se ativamente num processo de transformação de nossa sociedade. Eu concordava em parte com isso, me preocupava, queria agir em função dessas 
preocupações, mas percebia que a questão não era só essa. Pensava, tentava dizer: "A questão não é só o convencimento, a questão é emocional. As pessoas não mudam por causa de uma outra dimensão da realidade, que não está sendo reconhecida e pensada". Minha solitária certeza, incipiente, não se tornava acordo de todos. Meus tão queridos professores de ciências humanas, no pouco espaço que tinham na grade curricular de um escola profissionalizante, sempre nos desafiaram com temas de estudo novos e diferentes e muitos me incentivaram em minhas escolhas. Não basta apresentar argumentos para que tudo se transforme. Há a história, a economia, até as artes, diziam os amigos mais chegados. E eu achava, depois de ler Freud, Jung, que a psicologia era a escolha, o caminho. "Tem o desejo", eu poderia formular hoje, mas na época eu sabia que havia alguma coisa no discurso político - "Basta convencer, basta as pessoas serem razoáveis, terem bom senso e boa fé" - que não considerava o suficiente a condição humana.

Minha casa era um exemplo dessa força invisível. Não havia espaço para conversas sobre as coisas que eu aprendia na escola e que poderiam explicar nossa própria origem, nossos sofrimentos de migrantes. As pessoas não mudam por causa de um argumento bem apresentado. E minhas questões de juventude me empurraram para a psicologia.

Da parte de muita gente na faculdade as posturas eram de distância dessas questões, de uma escolha pelo trabalho clínico em que a pobreza, a militância apareciam como questões relativas à biografia de cada um, ao desejo: isso tudo era "uma questão da pessoa", privadas, biográficas. E as aulas de alguns professores encorpavam minha posição.

O que vai articular o desejo de se dedicar à psicologia como vocação e profissão é um questionamento político. Eu escolhi estudar psicologia porque meus questionamentos eram políticos. Eu me interessei por Freud porque eu percebia que ele talvez me ajudasse a entender coisas que pra mim apareciam numa ordem pessoal também, mas eminentemente política. Eu até alimentava certo preconceito com a clínica no início da graduação, via confusa e erradamente a escolha pelo trabalho clínico como oposto ao que eu mesmo buscava - pelo exemplo das pessoas que conheci na faculdade. Felizmente entendi que as motivações que costumam levar as pessoas para o trabalho na clínica são 
motivações de grande complexidade. Eu estimava compreender política psicologicamente supondo que a investigação psicológica é que vai permitir uma solução/compreensão mais radical desses problemas. Quaisquer desses problemas, não sopesados por uma profunda psicologia parecem insatisfatoriamente compreendidos, explicados, justificados e, ao mesmo tempo, inconsistentemente concebida a alteração/solução desses problemas. Busquei me tornar um psicólogo para quem se expõe a problemas humanos compartilhados de grande gravidade.

Os amigos e amigas mais próximos na universidade foram coincidentemente pessoas ocupadas com questões políticas, amigos de centro acadêmico, amigos da cooperativa, da pós-graduação. Amigos todos que tinham uma mesma preocupação.

O tipo de preocupação que me leva (nos leva) para a psicologia concerne a pessoas, mas pessoas expostas a questões de caráter bastante universal. São perguntas que não são referidas à biografia mas referidas à história compartilhada. Perguntas sobre a dominação, sobre o consentimento ou não da desigualdade que esperava responder encaminhando-me para a psicologia. Não eram os próprios problemas, eram os problemas do homem - problemas de todos sentidos de um modo próprio. Não perguntas por demais próprias por excessivamente privadas.

Muitos colegas foram para a psicologia por causa desse ponto, mas muito poucos vislumbravam saídas pra questões pessoais que também fossem políticas. A condição de classe de um jovem das classes pobres sem dúvida cria uma prontidão. Alguns aderem ao sentido e sentimento políticos de seus sofrimentos por causa dos seus sofrimentos, e não encontram seus sentimentos a partir de uma preocupação com o político. Encontram a preocupação com o político a partir de seus sentimentos privativos, o que é diferente desse movimento: partir de um problema colocado para todos nós e para cada um de nós, nos interessando pelos indivíduos a partir dessas questões, às quais todos são chamados a enfrentar - nossa vocação (minha e de meus amigos) pela psicologia era realmente de origem política. Mordidos por esse chamado chegamos à psicologia.

Havia na psicologia, portanto, além dos poucos que lá estavam por motivos os mesmos que os meus, os de vocação burguesa a quem pouco interessava as origens políticas dos sofrimentos psicológicos, mas também as pessoas que se vitimizam e 
aderem ao político como um desdobramento da sua vitimização - não são pessoas propriamente aguerridas e politizadas. Envolvido pelas questões do desenraizamento busquei - ainda busco - ver respostas para a história de minha cidade, para a história de muitos - e também para aqueles que marcaram minha própria história.

A quem falta a dimensão psicológica me parece faltar um pouco de profundidade. Os grandes cientistas políticos, Zeca me lembra, os grandes antropólogos são psicólogos sociais de mão cheia: Maurice Halbwachs, Pierre Clastres - só para dar exemplos aleatórios. Também são grandes psicólogos sociais Lucien Goldman, Lukács, Hannah Arendt - eles se pronunciam sobre a alma humana em meio a questões de cidade e outras questões de grande universalidade.

A psicologia é pra mim a profundidade da política - quem a recusa corre o risco de cair na superficialidade política e cair no ativismo ou, para quem a privilegia por demais o de se perder no subjetivismo do estritamente biográfico. Em geral, as pessoas de quem acabei mais ou menos me afastando eram todas ou avessas à política ou avessas à psicologia - daí que nenhuma amizade sólida pôde crescer. Esta afinidade essencial para que possa confiar plenamente minha amizade, na universidade, não foi diferente.

\section{O projeto da viagem}

Que circunstâncias envolvem a decisão de ir? Me lembro do ano de 1999: ainda terminando a graduação, desempregado depois de sair da livraria. O Japão aparecia como uma alternativa que poderia solucionar algumas questões. Muitas pessoas e circunstâncias já tinham transformado o Japão um lugar que desejava conhecer. Havia as motivações comuns a todos os dekasseguis: a esperança de conseguir um trabalho bem remunerado que me permitisse voltar pra cá e talvez comprar uma casa, começar a vida profissional com mais bem estruturado. Sofria demais com essa condição "itinerante", sempre mudando de casa. Não tinha muita esperança de trabalhar com psicologia- a cooperativa ainda era apenas um sonho que a Cris e o Egeu dividiam comigo.

Estava sem trabalho, não estava namorando, e sem esperança de construir algo em que vislumbrasse um horizonte. Nada me prendia no Brasil. Terminei o curso porque queira terminar, mas não via perspectivas na psicologia. O trabalho no Ática, por salário, 
alienado, duro, tinha acabado. E o ano anterior não tinha sido muito diferente. Me sentia só e sem valor.

E havia o desejo por conhecer, um dia, a terra de meus avós, de meu pai. Lia ("Musashi", "Rashomon"), via filmes, ("Kagemusha", de Kurosawa) visitava festas da colônia, buscava contato. Queria paraticar artes marciais, me lembrava do desejo de fazer judô na infância mas minha mãe não podia pagar. $\mathrm{O}$ kendo, por exemplo, aqui era caríssimo - mais uma vez o amargor de não participar por causa de dinheiro. Assisti a um documentário sobre metalurgia de espadas e me entusiasmei - me lembrava das noções de fundição e metalurgia da Escola Técnica.

Passei a faculdade atento aos temas da memória, das raízes, participação e eu via ali algo que queria viver por dizer algo a meu respeito. Estava cansado de ver o Japão por filmes, livros, outros meios que não fosse a experiência viva - outra lição dos mestres. Viver integralmente uma situação humana concreta, conhecer os meios materiais necessários a qualquer cultura. O Japão brasileiro me parecia falso, artificial, sem seiva. Havia nas conversas com o amigo Daniel um entusiasmo pela aventura, pela mudança ele pensava em abraçar definitivamente o jornalismo - as leituras e conselhos de Darcy Ribeiro: coragem, mais vale errar, se arrebentando, que poupar-se pra nada!

Eu não via sentido em ficar aqui. Quando iria, trabalhando aqui, poder pensar em ter um lugar meu? Quando teria outra chance de ir para um país que tinha relação com minha história?

Fiquei contente em decidir. Sabia que não seria fácil ficar longe de algumas pessoas, ter que aprender a língua lá - porque havia feito poucas aulas ainda no Crusp, que tive que interromper. Tinha confiança de que aprenderia e, além disso, as empreiteiras daqui faziam a oferta: os empregadores não exigiam domínio da língua.

Uma das primeiras pessoas pra quem contei que viajaria foi minha mãe. Eu achava que ela não me apoiaria - não esperava muito apoio de ninguém. Estava escolhendo a vida operária num país estrangeiro, carregando a certeza solitária de que iria conquistar outro tipo de bem. Brincava que iria embora, assistiria a Copa do Mundo de 2002, levaria minha mãe pra lá quando estivesse voltando e, aqui, compraria uma casa.

Fui bem direto: "Estou aqui no Brasil, sem trabalho, não sei o que vou fazer aqui e 
tomei a decisão. Estou pensando seriamente em ir para o Japão trabalhar”. E ela gostou. Ficou muito feliz com a decisão, me apoiou. Acho que pra ela era o alívio de pensar que o filho que ainda não tinha encontrado seu rumo na vida tinha a possibilidade de trabalhar e voltar com possibilidades de se estabelecer aqui, começar uma vida profissional mais bem estruturado. Fora o fato de sua admiração pelo Japão e pela cultura japonesa. Ela também conhecia histórias de sucesso financeiro de outros dekasseguis - minha prima Hiromi, por exemplo.

A partir daí a decisão se firmou. O Daniel e a Maya, colega que me deu as poucas aulas do nihongo já sabiam, apoiaram minha idéia. A Maya cautelosa, admirando minha coragem de ir sem falar a língua. O Daniel me deu de presente um pequeno guia de frases, com a dedicatória: “Não se perca no Japão!”. Depois contei pra outras pessoas: Vivi, Zeca, Cris e Egeu, Carlito, Roberta. As reações... Bem, acho que ninguém conseguiu dizer que eu não deveria ir - só o Zeca tentou me dissuadir conseguindo um contato para que eu tentasse dar aulas em Mariana, Minas Gerais, mas eu não tinha qualificação e, além disso, estava decidido. Estava desesperado aqui: sem ter onde morar, sem trabalho, perspectiva, desligado de qualquer movimento político, não estava namorando, nem fazendo análise, vivia de "bicos".

Contei para minha tia, ele me ajudou. Me levou ao escritório na Liberdade através do qual ela mesma foi. Eles cuidavam de tudo: arrumavam trabalho, passagens, visto, lugar para morar, mas só trataram comigo a respeito de custos na hora do embarque - o que me custou três meses de trabalho somado à última parte do dinheiro da causa trabalhista de meu pai, que saiu nesse meio tempo. Que alívio quando pude ter dinheiro suficiente para voltar para o Brasil se eu quisesse - os três primeiros e difíceis meses.

Mas antes de chegar lá houve esse período de espera pela viagem, que não tinha data confirmada porque tudo dependia do empregador japonês me contratar, mas não tinha uma data fixa: fim de janeiro, início de fevereiro de 2000. Nesse meio tempo conheci uma moça de quem gostei muito, mas não assumimos um namoro porque eu iria viajar. Foi difícil. Nessa espera comemoramos meu aniversário na casa do Alf, em janeiro. A oportunidade de trabalho que surgiu através do Zeca não tive nem coragem de procurar, porque me sentia despreparado, achva que não tinha condição. Não me achava um psicólogo. Mas não ter tentado isso doeu 
Quinze dias depois me avisaram o dia de minha saída. A minha bagagem era pequena mas não pude deixar os livros pra trás. Lá mal consegui tocá-los, mas estavam comigo: Hannah Arendt, Simone Weil, Elcéa Bosi, Freud, Winnicott, Nelson Rodrigues falando de futebol, Rubem Alves, João Antônio, João Cabral.

\section{JAPÃO:}

Vivi no Japão de março a novembro do ano 2000, na cidade de Fujinomiya, duzentos quilômetros ao sul de Tokyo. Pequena cidade aos pés do Monte Fuji, existe em torno de suas indústrias, principalmente de papel e alimentícia, mas onde ainda parece haver grande importância econômica da agricultura do chá, dado o número de pequenas e grandes áreas cultivadas espalhadas pela cidade. $\mathrm{O}$ aspecto geral era de cidade agrícola muito próxima de centros industriais, modernizada mas que conserva ainda sua antiga vocação. Trabalhei durante esse tempo em dois lugares: em meu primeiro mês numa fábrica de papel, nos sete meses restantes numa fábrica de aparelhos de ar condicionado. Nesta última, durante o mês de junho trabalhei em seu edifício central, no bairro chamado Miahara, onde se encontravam as linhas de montagem; o restante do tempo, entre abril e maio e entre julho e novembro, num pequeno edifício, chamado SK, onde se produziam peças que alimentavam as linhas no prédio central. Ao lado deste prédio menor, que ficava a algumas quadras de Miahara, ficava também o lugar onde morei, um alojamento de dois andares pertencente à fábrica.

\section{Chegada}

No avião, apesar da frieza dos brasileiros à minha volta, estava feliz, olhando o Pacífico pela janela. Me lembro de minha felicidade por estar lá onde tanto quis estar e do silêncio no aeroporto. Gostei muito, muito. Foi o mesmo silêncio que experimentei no topo do Fuji-san? Com meu passaporte de brasileiro fui encaminhado para a fila dos estrangeiros - diferente da fila dos locais e estadunidenses. Me lembro do funcionário que ficou me perguntando se eu havia trazido animais, remédios ou drogas ilícitas e 
verificou minha mala de livros - não acreditou quando eu lhe disse o conteúdo.

O primeiro encontro foi com a Mari, do escritório da empreiteira que me contratou. Fui surpreendido por sua frieza - precisava muito de alguém em quem confiar, com quem contar - mas acho que minha alegria por estar lá não deixou que eu ficasse realmente incomodado. Estava entusiasmado com os pessoas e lugares que via.

Ela me deixou num alojamento de outros trabalhadores do escritório, para me levar no outro dia até meu local definitivo. Tinha comprado algumas coisas pra mim, que iria descontar de meu salário: comidas, futon. Ela não se importava comigo. Isso gela a alma, e nos torna atentos pois tudo parece sinalizar quen estamos sozinhos naquele lugar.

\section{Primeiros dias}

Naquela noite havia apenas dois rapazes brasileiros no alojamento, um paulista e outro paraense. Estavam esperando a chegado de um terceiro, amigo deles, para saírem.

Me chamaram para ir, mas quando disse quanto dinheiro tinha comigo me disseram para ficar, pois era o suficiente apenas para passar o mês. O mesmo rapaz do Pará me deixou ver alguns filmes em sua tevê enquanto eles saíam, pois estava cedo e meu quarto era vazio: não tinha nenhum móvel ou conforto: nem cama, nem aquecedor. Fazia muito frio.

"O que acaba acontecendo é que no final você não se acostuma mais com o Brasil; não sei porquê, você até quer, mas você não se acostuma mais; você vira um japonês. E, aqui, você é brasileiro." Talvez essa tenha sido a primeira frase que tenha de fato ficado em minha memória em minhas primeiras horas de Japão. Foi dita por um rapaz paraense, que conheci no alojamento onde passei minha primeira noite e que já estava pela segunda vez lá, trabalhando. Ao todo, somando suas idas e voltas, três anos, acho. Eu havia chegado a um pequeno prédio, dois andares, um tanto vazio. A Mari tinha me buscado no aeroporto e me deixou lá sem muitas explicações além da que no dia seguinte iríamos para minha moradia definitiva. Deixou-me um futon (espécie de edredom japonês), uma sacola com lanches, e mostrou-me o quarto onde passaria minha primeira noite: pequeno $(2,5 \times 3 \mathrm{~m})$, absolutamente vazio e gelado (não havia móveis nem aquecimento e estávamos no final do inverno japonês). Antes de ir, apresentou-me para 
os dois rapazes que estavam lá no momento e pediu-lhes que me auxiliassem no que eu precisasse. Um deles, na conversa antes de seu passeio ao sunaco (corruptela japonesa de snack bar) programado para aquela noite, me contou sua trajetória até ali e me disse essas primeiras palavras, que guardei. Depois que eles saíram, fiquei lá. Olhei o prédio, experimentei o chuveiro, comi alguma coisa, escrevi para casa, tentei enganar o frio muito - que fazia. Estava só, absolutamente só. Não haveria quem pudesse me ajudar a partir de agora, ninguém sabia quem eu era, eu era apenas mais um brasileiro no Japão e no entanto junto com o medo estava a alegria de estar exatamente onde eu gostaria de estar havia tanto tempo: o Japão de meus ancestrais. Tudo era a mais pura possibilidade: maravilhoso e terrível.

No dia seguinte encontrei os mesmos rapazes e eles me levaram no mercado. Como estava preocupado com o dinheiro que tinha, comi o que pude reconhecer e era mais barato - miojo, de novo. Logo depois a Mari apareceu e fomos embora. Nunca mias vi aqueles moços.

Fui levado pela Mari para a prefeitura, onde tirei meus documentos com ajuda do funcionário que falava japonês. $\mathrm{O}$ que me marcava em todos os encontros era que ninguém foi hospitaleiro, caloroso ou pareceu preocupar-se comigo - eu me sentia apenas uma parte da rotina de trabalho de cada um.

O segundo alojamento era uma casa velha, adaptada para servir de alojamento. Tinha partes de alvenaria, outras construída no estilo tradicional. As salas que comportavam essa mudança tornaram-se quartos para todos. Escolhi o que mais tinha aspecto japonês: chão de tatami, paredes de madeira e um guarda-roupas embutido. A porta do quarto e do guarda-roupas eram de correr, idênticas. Uma luminária descia por um fio no teto, central, e era ligada por um puxão no fio que dela descia até a altura de uma pessoa sentada no tatami. Era um quarto bem pequeno, velho, algum vento frio entrava pela janela - que não era janela, era outra porta de correr, de vidro e que dava pra rua. Tive que dar uma boa limpada nele, não havia trancas - inclusive na janela - o que me deixava preocupado às vezes, mas era o mais aconchegante e, como disse, "japonês".

\section{Monte Fuji}


Meu primeiro dia de trabalho começou cedo, por volta das seis e meia - levantei mais cedo que o necessário pois não queria de jeito nenhum me atrasar. Pus o uniforme, meio folgada a calça, que segurei com um cinto, por baixo muita roupa para suportar o frio, tomei um café e saí, todo de azul, boné da empresa na cabeça. $\mathrm{O}$ arrozal em frente à casa estava geado, sem água ainda, esperando o verão. Fazia sol. As casas, algumas com aqueles telhados típicos, suas bordas apontando o céu, outras de aspecto aparentemente mais improvisado, com paredes de madeira ou mesmo revestidas por chapas onduladas, metálicas, talvez proteção contra o frio. Tubos de gás do lado de fora, ausência de muros altos, ruazinhas estreitas por onde os carros passavam apenas um por vez, com um dos dois motoristas gentilmente dando passagem para o que vinha em mão contrária (!!!), letreiros todos pequenos repletos de ideogramas lindos que não entendia - tudo era muito simples; podia-se ver, pobre; mas de uma pobreza remediada, porque os objetos eram antigos, bastaste usados, não substituídos por outros mais modernos, mas não depredados: construções que um dia foram completas, novas, ricas talvez, não impedidas pela necessidade, pois eram casas e ruas cuja construção não se interrompeu nalgum ponto de sua história por falta de recursos para compra de materiais, preteridos por outras urgências das famílias, como tantas vezes vemos nos bairros pobres do Brasil, com suas casas de alvenaria exposta; a pobreza em Fujinomiya se mostrava no empenho em conservar aquilo que, para ser trocado, seria dispendioso demais aos que moravam naquelas casas.

Fui andando pelo caminho que havia feito no dia anterior, já pensando em não perder a hora por ter-me perdido. Segui a rua até o final, entrei à direita, de novo à direita, e segui em frente, em direção à ponte que atravessava o rio, lindo, de Fujinomiya. Era atravessá-lo e seguir a outra metade do caminho, seguindo à direita, pegando à esquerda em direção à linha do trem e, finalmente, à direita já quase na fábrica. Este percurso abstrato era um jeito de me garantir minimamente contra a desorientação que experimentava naquelas ruas sem calçada, com carros circulando em mão inglesa, invertida em relação à nossa. Tinha medo de me perder naqueles caminhos estreitos. Mas, na ponte, me encantei com a visão dos pescadores de pé no meio do rio pedregoso. Meus olhos correram e, aí, vi o Fuji-san... 
Me emocionei. Uma experiência, uma aparição do sagrado, depois de ele ter se escondido atrás do tempo nublado e da chuva fina desde minha chegada. Gigantesco. Lindo. Azul, com seu topo branco surgindo no céu, o Monte Fuji parecia ter aparecido naquele momento, flutuante ali, vindo do nada, com uma presença incomum, diferente da simples visão de uma montanha, uma presença que só o que tem vida e alma pode ter. Não tive como não ficar lá, admirado, mudo de beleza - num conto de Galeano, um menino que pela primeira vez vê o mar diz ao pai: “Me ajuda a olhar!”. Que memórias esse encontro me despertou, o que me dizia? Ah, como eu queria que vocês vissem isso... O Fuji-san é inesquecível. E esteve sempre comigo nesses oito meses de experiência de trabalho no Japão: nos intervalos sempre curtos demais para recobrar-me da exaustão e da tristeza, na hora do almoço na fábrica de papel, em que aparecia em sua luz mais linda e viva, me incentivando a ser forte, sereno, perseverante, intenso, paciente, fiel; da minha máquina na outra fábrica, pela única janela daquele lugar que permitia vê-lo, ali, só ele me vendo, e eu, desafiado a ser virtuoso como o espírito daquele deus vivo que a mim se apresentava com seu corpo glorioso. Poder estar diante de algo tão belo me fazia pensar sempre que tudo estava valendo a pena. O "Fuji-san", que um dia também me deixou subir até seu topo, numa noite linda em que mais que nunca fui homem de fé, e em silêncio e só assisti ao mais belo nascer do Sol. Fujiyama.

\section{Empreiteiras}

Cheguei na fábrica antes da hora, mesmo com a parada para olhar o Fuji-san, mesmo com o estranhamento com as ruas movimentadas, cheias de carros em mão inglesa perto da fábrica. Ainda tinha visto no caminho crianças pequenas indo juntas à escola, bonezinhos vermelhos na cabeça, tão pequenas e andando sozinhas. Segurança. Entrei pela saída dos caminhões, ainda parados, na lateral da fábrica, pois vi a Mari lá, conversando com um e outro enquanto me esperava. Entramos e fomos conversar com alguém que, pude supor, era o encarregado do pessoal: um rapaz jovem, bonito e sério, que não sorriu ao me cumprimentar. Fomos para uma sala cheia de ferramentas bem arrumadas nas paredes tomadas de prateleiras e desenhos industriais, além de bancadas nas laterais; na transversal da sala estreita havia uma mesa onde o rapaz se sentou, com 
seus movimentos lentos e sua cara fechada, e acendeu um cigarro. Eu e a Mari nos sentamos à sua frente.

Começaram a conversar em japonês, enquanto eu ficava atento a tudo. Mas acho que, naquele momento, eu era atento a apenas uma coisa: alguém que se mostrasse e me acolhesse como um amigo, que me orientasse, me dissesse que tudo estava bem; que sorrisse e me explicasse com calma os cenários por onde eu andara até então, o sentido do que ia acontecendo e me escapava, porque tudo era muito novo, acontecia rápido demais para meu entendimento, estava há poucos dias num país novo, cuja língua não dominava minimamente. Nada disso até então havia acontecido, a não ser em rápidos e inconstantes momentos, com os colegas de alojamento que me ensinavam uma coisa ou outra, em geral de ordem prática, sobre as ruas, mercados, nossa moradia, conforme se apresentava a ocasião. Ninguém me recebia propriamente, nem explicava nada. No fundo, desde que saí do Brasil, estava ansioso e tinha muito medo. E estava perdido, mas em prontidão. Pois só tinha a mim mesmo.

Me perguntaram se eu falava japonês - ele falou, ela traduziu. "Não", mas ela já sabia disso, estranhei: por que esta pergunta, se ela já tinha esta informação há muito, quando eu ainda estava no Brasil?. Por várias vezes ele tentou falar comigo, como se eu pudesse entender qualquer coisa. "Sumimasen" ("Desculpe") era o máximo que eu sabia e podia dizer, tentando ser educado na minha vergonha por não poder responder às suas palavras.

Depois de conversarem um pouco mais, ela me perguntou dados pessoais enquanto ele preenchia uma ficha, com a cara mais séria ainda - fazia uma expressão de gravidade, de quem parecia dizer ser difícil poder me encaixar em qualquer setor da fábrica, de quem se arriscava a cometer um erro me contratando. Então, me explicaram que, como eu não falava japonês, eu iria trabalhar no soko, que eu não fazia idéia do que era, e que quando eu estivesse mais acostumado viria para as máquinas, pois nelas, no turno programado para mim, só havia japoneses. Quando saí do Brasil, o acordo era que trabalharia nas máquinas, que era serviço menos pesado, mesmo não falando japonês, coisa que fiz questão de frisar quando assinei o acordo aqui. Depois de algum tempo, percebi que aquilo era ardil de empreiteira, coisa infelizmente muito comum no Japão: retêm passaportes, descontam mais do que o justo do salário alegando gastos inexistentes 
com aluguel, energia elétrica e uniformes, ficam com parte do valor ganho por hora trabalhada. Tive muitos problemas com a Mari e seu escritório por causa desse mau começo.

\section{Nos fundos da fábrica}

O soko ("fundo" em japonês) era o depósito, onde as caixas de papel já prontas para serem distribuídas aos compradores chegavam para serem empilhadas em bases, grandes estrados de madeira, e essas bases erguidas por empilhadeiras para serem guardadas ou carregadas em caminhões. Meu trabalho era emplilhá-las, logo que chegavam pelo elevador contínuo e escorregavam pela esteira, vindas da produção lá dentro.

Lá trabalhei com duas pessoas: Ikematsu-san e Mori-san, o primeiro na mesma condição que a minha, só que com mais tempo de fábrica, o outro realizava a mesma atividade, mas era como que um "responsável" por tudo, pois era mais velho, mais experiente e, como era japonês, não tinha problemas com a língua. Cláudio Ikematsu parecia ser jovem, era alto, magro, e tinha um jeito um tanto distraído, alheio ao que estivesse ao seu redor. Mori era sério, calado, mal humorado e, desde o começo, mostrou uma característica que me incomodou enquanto estive ali: era sorridente, falador e brincalhão com outras pessoas, em especial com o chefe do soko, Sassamoto, enquanto que, quando me respondia, era sempre de cara fechada e com monossílabos, apesar de falar bem as duas línguas. Quando a iniciativa da palavra era dele, era sempre em tom de voz irritado, e para dar ordens. Nunca me cumprimentava quando começávamos o dia.

Sassamoto era o chefe do setor. Japonês enérgico, voz estridente e rasgada, operava empilhadeiras. Dele tomei várias broncas, sempre que errava, e principalmente no começo, pois não sabia fazer o trabalho. Uma vez porque iniciei de forma errada a ordem de empilhamento de um tipo de caixa. Outra porque o nó que tinha dado na última camada de caixas, com a corda que servia para mantê-las coesas nas manobras das empilhadeiras, não estava simétrico. Lembro que ele me puxou pelo braço gritando coisas ininteligíveis e me apontava o erro, e muitas vezes eu só entendia o que se passava porque o Ikematsu me traduzia e depois ensinava como fazer, enquanto o Sassamoto 
olhava e gritava nos apressando. Me sentia um cachorro que tem o focinho esfregado no xixi feito em canto errado. Não gostava dele e do Mori, que nessas vezes até piada fazia com o chefe. Mas tinha, mais do que tudo, medo do que seria se eu fosse embora dali, ou fosse despedido e ficasse sem lugar onde morar, sem ter como me manter. Daí engolia.

O tempo corria lento no soko. Eu chegava lá por volta das sete e quarenta, quarenta e cinco, depois de ter batido meu cartão lá dentro, e começava a varrer, com uma vassoura de bambu, toda a área, uma tarefa que todos, inclusive operadores de máquina, assumiam, e que parecia momentaneamente quebrar diferenças hierárquicas entre nós. Quando chegava muito antes, também ligava as luzes, fortes e frias, as únicas que via o dia todo. Além disso, antes do toque do sinal em que ligávamos o elevador e a esteira com as caixas começava a correr, arrumava as cordas que seriam utilizadas nas amarrações do dia. Tudo tinha seu jeito e tempo certos de fazer: corda enrolada errado era bronca, mal humor e mais distância pessoal do Mori. Eu empilhava caixas sem parar. Corria muito para que as caixas não se acumulassem na esteira, e atento para não iniciar uma pilha de forma errada. Os estrados saíam e chegavam violentamente, batendo barulhentos no chão, trazidos pelas empilhadeiras, e nós devíamos tomar cuidado, pois algum poderia nos acertar os pés, ou mesmo cair sobre alguém.

Lembro que, na primeira semana, não conseguia erguer meus braços, na hora do banho, para lavar meus cabelos, de tanta dor. Um dia, de brincadeira, fiz as contas de quanto peso movimentava por dia, erguendo caixas da esteira para o alto das pilhas que fazíamos para as empilhadeiras: aproximadamente dez toneladas, cada um dos três. Mas o medo, o estar só, a falta do consolo dos colegas que não vinha me faziam continuar. "Você acostuma", foi só o que ouvi. À minha volta, na fábrica e no alojamento, era uma indiferença que me chocava, e que era provocada pelo trabalho contra o qual não valia nada se revoltar. Você acostuma... Era verdade, pelo menos fisicamente: ficar forte, pegar o jeito para erguer as caixas, tudo isso ia garantindo certo conforto, certo tempo para respirar.

Às oito tocava o sinal, e a esteira começava a correr. Caixas desciam pelo elevador e corriam à nossa frente. Não parávamos, praticamente. Se quatro ou cinco caixas se acumulassem, a esteira parava, com ela toda a cadeia desde lá de dentro, e a culpa era nossa. Algumas vezes parou por culpa minha. Mas logo, nunca mais parou: sei 
que era bom trabalhando. Naquele lugar, eu sei que era útil: muitas vezes resolvendo suas dificuldades, antecipando problemas; chegando antes de vários deles pela manhã e depois do almoço já pontualmente em minha posição antes da esteira começar a andar; dando tudo de meu esforço, sei que mostrei meu valor. O Cláudio também fazia as contas, comentava coisas parecidas com essas, nos comparava com outras épocas para concluir que nossa produção no soko era a melhor que ele já tinha visto ou ouvido falar.

O Mori nunca sorria. Achava que me odiava, eu que tinha chegado sorrindo, puxando papo, fazendo perguntas (a ele, japonês fluente também em português), talvez demais, querendo encontrar companheirismo agora que, trabalhando, havia de fato começado minha vida lá. Como isso devia incomodá-lo, não sei por que, e as coisas só pioravam quando eu fazia alguma coisa errada. O que será que eu não entendia daquele lugar? Por que eu o ofendia tanto? As coisas ficavam assim bastante tensas entre nós. Certa vez, na correria, ansioso que eu ficava mas lutando para trabalhar mais que ele, dei um tropeção na base de madeira e caí com força. No chão, sem querer (mais que sem poder) me levantar, quis chorar. Não podia acreditar naquilo tudo. E foi no banheiro de casa, à noite, quando vi minha unha do dedão arrancada que aí sim pude chorar bastante porque lembrei que, ao invés de rir de mim, o Mori me ajudou. Enquanto me levantava, vi seu rosto diferente: quase poderia dizer, nunca terei certeza, preocupado, e disse seco mas sincero, "toma cuidado".

\section{Mudança de emprego, yakuza}

Depois do meu primeiro mês na fábrica de papel, fui para a Sato Koki, que fabricava as partes mecânicas dos aparelhos de ar condicionado da Toshiba. Dias antes de começar, fui até lá fazer um teste. Fui apresentado aos meus futuros chefes e os acompanhei até o segundo andar da fabrica, uma unidade menor da fábrica maior que ficava a uns quinhentos metros de distância e fazia as peças menores e soldas mais delicadas que exigiam máquinas especiais.

O teste foi realizar a tarefa de encaixar peças em formato de " $U$ " em pequenos suportes, todos dispostos em círculo numa mesa giratória. As peças sofriam a ação da máquina, que as deformava de modo a terem furos na base do "U" (que encaixados 
ficavam de ponta cabeça) para então serem retiradas manualmente por mim. Eu ainda verificava algumas com um eixo de prova, no diâmetro exato em que elas deveriam ficar. Foi um teste simples, a tarefa fácil porque a velocidade do giro da mesa estava reduzida e, embora tenha me atrapalhado algumas vezes, consegui demonstrar habilidade em parar o conjunto todo sempre que algum suporte ficava sem peça. Fiz umas cinqüenta peças, me pediram para parar, desci com eles depois de conversarem um pouco, meus chefes voltaram ao trabalho e eu recebi a notícia do Sano-san, responsável pelo pessoal da fábrica, que estava contratado, que deveria começar na última semana de trabalho do Mário (o colega que me arranjou tudo) para que ele me ensinasse seu trabalho.

Foi um grande alívio ouvir as palavras do Mário me traduzindo as daquele senhor tão sóbrio. Naquele dia tinha faltado na fábrica de papel, sem avisar ninguém, correndo por isso o risco de ficar sem emprego nenhum. Um alívio, uma vitória, especialmente sobre aqueles caras que me tratavam tão mal lá no soko, para onde fui com um sorriso no rosto nos últimos dias em que trabalhei lá, pois nada mais importava para mim senão mostrar que saía por escolha minha, e trabalhando mais ainda que todos eles naquele lugar enquanto ainda estivesse lá. Dois dias depois, mais ou menos, eles me colocaram para trabalhar com o Kenzo-san, com quem fiquei até o fim do mês.

Quando comecei na Sato Koki, tive que aprender o trabalho do Mário. Mas antes desse episódio, ainda vivi outra coisa relacionada à minha saída da fábrica de papel: o fato de ter-me posto livre da Mari e da empreiteira para quem ela trabalhava e que havia me recrutado aqui no Brasil, à custa de quase três meses do meu salário só para pagar os custos de uma viagem que, em condições normais, teria custo três vezes menor.

No dia em que faltei ao trabalho, enquanto eu fazia meu teste, a Mari foi acionada pela fábrica, sendo avisada da minha falta. Não me achando no alojamento cedo na manhã, não pôde fazer nada até que eu estivesse de volta. Quando mais tarde me encontrou, dei-lhe a notícia de que estava indo para a Sato Koki: afinal, estava fazendo um trabalho que não era o que tinha sido combinado aqui no Brasil e ao contrário, estava no serviço mais pesado da fábrica, e sem o direito de, ao menos, fazer hora-extra com o adicional noturno - único argumento que, todos sabiam, fazia valer a pena o trabalho no soko, embora eu estivesse longe de querer ter realmente esta chance. Dito assim, nosso acordo comercial não havia sido honrado, e eu podia sair. Além disso, minha coragem se 
apoiava também no fato de que nem meu passaporte nem qualquer outro documento estavam com ela, fato (ilegal) comum entre os brasileiros contratados de sua empreiteira.

Só o que precisava dela era receber meu salário, mas foi então que começou meu problema, pois ela começou dizendo que não iria pagar-me. Depois, que eu tinha até o final da semana para sair do alojamento, senão ela descontaria mais um mês de salário. Por aí foi e, quando pagou-me, havia acrescentado uma série de descontos por pequenas despesas que, de início, eram responsabilidade da empreiteira: uniforme, crachá, etc. E havia feito o cálculo do salário com um valor-hora inferior ao que todos os brasileiros recebiam na fábrica. Aquela mesma que havia me recebido no aeroporto, por quem eu havia simpatizado e tido a esperança de poder contar como um apoio naquela terra desconhecida, tinha se transformado numa pessoa rancorosa, vingativa, injusta, grosseira, uma senhora de engenho tão cruel quanto qualquer outra. Reclamei, fui até o escritório, discuti e bati o pé com quem estava lá, disse que iria atrás de quem me defendesse na justiça (o que de fato fiz, recorrendo a um escritório do Ministério do Trabalho do Japão).

Tive medo de morrer, pois algumas pessoas me diziam, covardemente, pois nunca quiseram me ajudar, que a empreiteira era de um yakuza, e que mafiosos "sumiam" com gente que fazia como eu. Me lembrava que uma vez um amigo do Ikematsu-san apareceu todo machucado. Tinha apanhado do pessoal da yakuza - a máfia de lá. Ainda andei pelas ruas receoso por algumas semanas, mas nada aconteceu.

\section{Kenzo-san e a caixa mágica}

Encaixado por um escritório de recrutamento aqui no Brasil, fui funcionário de uma fábrica de papel higiênico. Em meu primeiro mês, trabalhei no depósito, carregando as caixas do papel produzido e pronto para ser posto nos caminhões para distribuição. Trabalho duríssimo, chegava a movimentar cerca de nove toneladas de peso por dia, das esteiras por onde desciam as caixas para os estrados formando pilhas de caixas que montávamos e amarrávamos e que as empilhadeiras movimentavam. Isso me fez procurar outra ocupação, e acabei tendo sorte: conheci uma pessoa que, por estar retornando para o Brasil, fez-me seu substituto na fábrica de aparelhos de ar condicionado onde permaneci até minha volta para casa. Porém, em minhas duas últimas 
semanas na fábrica de papel, fui colocado no interior da fábrica, junto às máquinas que, de enormes bobinas de papel, enrolavam os tubos menores que seriam cortados nos rolos normais que usamos quotidianamente, para depois seguirem para o setor de embalagem. Lá, conheci Kenzo-san ("san”, em japonês, é termo respeitoso, de certa cerimônia, equivalente a "senhor" em português; mas para mim sempre terá conotação mais carinhosa): cinqüenta e cinco anos, muito magro, sério, era o único japonês que falava português em toda a fábrica, pois havia morado alguns anos aqui, inclusive tendo se casado com uma brasileira e tido um filho, Kengo, de onze anos. A família toda estava no Japão, com os mesmos objetivos financeiros de todo dekassegui.

Kenzo-san era impressionante: jamais vi alguém trabalhar tanto, com tamanha disposição e tanta atenção ao que fazia. Mais impressionante ainda por sua condição física e por sua idade, atravessando nossas longas jornadas de oito, dez horas de trabalho duro e quase ininterrupto. Raras e rápidas eram suas paradas: costumava me dizer (e assim me fazia proceder): "sempre arrume alguma coisa para fazer, pois pega muito, muito mal um japonês te ver parado" - havia, aí, uma identidade clara dele conosco, pois dizia isso como se fosse um brasileiro, apesar de sua naturalidade. Éramos dois brasileiros pela saudade daqui e pela condição de trabalhadores na mesma situação, na mesma oposição forçada àquele que cumpria o papel do patrão: o japonês.

Mas nós não começamos aí: naquela segunda-feira, estava cumprindo minhas tarefas de rotina no depósito antes que o sinal de início de trabalho tocasse, quando fui chamado por meu supervisor para dentro da fábrica. Lá, diante de outras duas funcionárias responsáveis pelo setor, chamou Kenzo-san, conversou com ele e do pouco que entendi (pois não falo japonês), disse-me que era ali que eu iria trabalhar naqueles dias.

Foi só o que deu tempo de ouvir: rápido, Kenzo-san me olhou, estendeu-me a mão e já disse: "Tudo bem? Vamos trabalhar. Preciso te explicar as tarefas logo". Não houve agressividade ou antipatia no tom, mas a situação um tanto urgente me pegou desprevenido. Quando vi, o sinal já estava tocando, as máquinas imediatamente começaram a funcionar e eu seguia afobado Kenzo-san por todos os lados.

Minhas tarefas eram muitas. Varrer todo o saguão: tinha aproximadamente trinta metros; à direita estavam as máquinas; à esquerda a área de estacionamento das bobinas 
que pelo elevador chegavam do subsolo; e no centro a nossa área de circulação, que acumulava pó de papel do atrito das máquinas e que precisava ser impecável na limpeza porque senão os rolos ali produzidos ficariam sujos. Atrás e embaixo das máquinas, agachado com uma esponja de palha, limpar o chão de chapas de aço da mesma sujeira agora impregnada de óleo, para evitar os mesmos rolos sujos e o eventual escorregão e queda de algum operador. Retirar as bobinas, de aproximadamente um metro e meio de diâmetro de papel, dois metros e meio de comprimento e quinhentos quilos, rolando-as do elevador (difícil controlá-las só com a força do corpo), prendendo-as no miniguindaste e manobrando-as até a máquina que estivesse terminado sua bobinas ou até a área de estacionamento. Ajudar os operadores a retirar o eixo da bobina terminada na máquina para, com o guindaste, encaixar a próxima (tarefa que exigia cuidado, pois era perigosa por causa do peso da bobina e dos movimentos automáticos da máquina no encaixe). Retirar o eixo desencaixado, limpando-o antes de descê-lo pelo elevador aquela que, entre tantas outras era a pior tarefa: com um estilete, de cócoras, cortar o resto de papel ainda enrolado no eixo, recolher o resto, varrer o pó, e jogar esta resma de papel no poço ao lado da área de estacionamento, onde solventes preparavam este material para reaproveitamento. A tarefa era terrível, pois a posição era dolorosa para as costas e mãos e não havia posição do corpo que tornasse a limpeza do eixo suportável. Além disso o estilete a toda hora quebrava ou se desgastava, pois o papel é um material muito difícil de cortar em nível industrial por ser abrasivo e oferecer grande atrito a qualquer ferramenta de corte. E a cada limpeza o chão ficava imundo de novo.

O ritmo era ininterrupto para estas tarefas principais, pois as máquinas produziam muito pó de papel e o chão estava constantemente sujo; as bobinas novas não paravam de serem mandadas pelo elevador e as usadas de terminar nas máquinas - sempre, portanto, havia eixos para serem limpos; e sempre também havia um detalhe ou outro para ser resolvido. Tudo sob o olhar severo dos chefes e responsáveis sempre prontos a denunciar um erro ou "corpo mole".

Meus primeiros minutos pareceram horas, correndo atrás de Kenzo-san, que apenas ia me dando as ordens. Eu mal sabia por onde andava, só prestava atenção para não me machucar. As tarefas vinham uma atrás da outra, num ritmo muito acelerado, pois todos os setores da fábrica ou convergiam ou dependiam de nosso trabalho. Muito 
mais difícil que o trabalho no depósito, pela variedade de tarefas simultaneamente se acumulando, pela responsabilidade, pelo controle dos chefes, pelo esforço físico ao menos equivalente ao carregar de caixas, esforço que agora envolvia bolhas na mão, maljeito constante na execução, dor.

Lembro, que, após umas duas horas de trabalho, quando o ciclo de tarefas começava a se repetir, finalmente Kenzo-san me chamou e conversou comigo. "Pronto, agora você já sabe quais são as nossas responsabilidades. Este é o nosso setor ...” e continuou falando, agora me explicando tudo que eu havia feito até ali, porque deveria fazê-lo, a que parte do trabalho dos outros estava ligado, o nome e tipo de cada máquina, cada tipo de papel, nome de cada pessoa que víamos etc, etc, etc... E, rápido, me chamou de volta para o trabalho. Tudo o que eu estava fazendo até então, com medo de errar, afobado, sem nenhum entendimento ou tempo para refletir, mudou em minha consciência. Só pude olhar, num misto de agradecimento e espanto, para o Kenzo-san, que já estava ocupado em seu trabalho e me acenava determinado para que eu me apressasse no meu.

Pedagogia nipônica: primeiro fazer; depois, compreender.

Aquela semana correu bem. Antes de tudo, gostava do meu sensei (professor, literalmente, "aquele que está à frente, que chegou antes, no caminho da vida"). Terminava os dias absolutamente exausto, mal podia acompanhar seu ritmo, mas aproveitava a companhia nos segundos esporádicos que encontrávamos: às vezes encontrávamos algum canto de máquina sujo para limpar enquanto conversávamos. Mas sempre era muito pouco o que falávamos: nosso companheirismo vinha dos problemas que resolvíamos juntos, ou um pelo outro. Além disso, como todo bom japonês, Kenzosan era de falar pouco - se falava, era pelo olhar. Mas não dá vontade de falar, quando se trabalha daquele jeito: pensar sobre o que se faz e porquê se faz é quase insuportável - o que pude compreender era quase nada, e não diminuía a percepção de que eu não fazia a menor diferença para os patrões: as máquinas e tarefas que executava o tempo todo me lembravam disso, indiferentes à nossa alma e corpo de trabalhadores e às nossas infelicidades miúdas e inúteis.

Quando Simone Weil escreveu sobre sua experiência de trabalho na fábrica da Renault, disse: "é quase impossível não ficar indiferente e brutal como o sistema em que 
se está metido". Tornamo-nos elementos da máquina e, obrigados a seguir sua cadência, evadidos da reflexão pelo rebaixamento implacável, esquecemos o outro.

Foi assim que cheguei para trabalhar com Kenzo-san, era assim que ele próprio parecia agir com novos companheiros: armado de uma capa de indiferença a tudo que fosse humano, necessária a todo operário para atravessar seu dia. A contradição, porém, nunca nos deixa esquecer de quem somos, ou de que estamos na companhia de alguém: sua primeira atitude comigo, minha vontade de ajudá-lo o mais que pudesse naqueles dias - é isso, e mais nada, que nos sustenta quando se trabalha na fábrica.

Eu me perguntava espantado, todos os dias: como ele agüentava fazer tudo aquilo sozinho, antes da minha chegada? Como podia ter essa atitude séria, inabalável, incansável? Isso só aumentava meu espanto. Um dia, enquanto seguíamos nossas rotina de máquinas-homem, Kenzo-san foi responsável por mais um momento de revelação: "Você trabalha bem. Aprendeu tudo rápido, está me ajudando. Antes eu não gostava de ajudante, porque sempre faziam coisa errada, mais atrapalhava que ajudava. Você é bom. Só um pouco afobado - fica mais tranqüilo, ô rapaz! - mas é inteligente. Aprendeu rápido, está me ajudando. Não vai para outra fábrica não, não vai embora não. Fica aqui me ajudando".

Foi a única vez em que vi Kenzo-san demonstrar que estava cansado. Que ali também não se sentia em casa. Duas semanas depois, que passaram dolorosas mais pelo seu pedido que pela rotina desumanizante, mas em que agradecidos nos encontrávamos e nos despedíamos, fui embora.

“O operário não sabe o que produz, logo não tem o sentimento de ter produzido, mas de ter-se esgotado no vazio. Gasta na fábrica, às vezes até o limite extremo, o que tem de melhor dentro de si" (Simone Weil, Experiência de vida na fábrica)

Havia, naquela seção impessoal, um objeto sagrado. O ambiente, mesmo sendo como era, limpo, com pintura clara e nova, as máquinas brancas e brilhantes, não poderia ser cenário mais contrastante com o que vinha na alma de quem lá trabalhava. Das outras seções sempre ouvia histórias de humilhações sofridas por colegas, do corpo que não nos pertencia lá dentro mas que, quando havia visitas de excursões escolares ou executivas, estavam sempre vestidos em belos uniformes. As máquinas eram caprichosas em suas exigências, implacáveis com o erro, falavam alto em seus atritos e encontros de aço com 
aço, que agrediam nossos ouvidos. Eram duras, grandes, pareciam sempre indestrutíveis e onipotentes. Seu sangue de eletricidade, óleo e ar comprimido pulsava sem nunca precisar diminuir a cadência. E éramos nós, homens, contra elas e suas formas, seu corpo que não acolhia nossa passagem por ali. O Japão, o "Império dos Signos": quantas beleza humana inscrita na história dos artefatos históricos: nos quimonos e adereços delicados, nos templos grandiosos, nas cerâmicas da cerimônia do chá, nas carpintarias das casas e utensílios, e no símbolo máximo da artesania da espada samuraica - nada disso, porém, na fábrica.

Há uma dimensão de reencontro com o passado na experiência de alguns daqueles que vão ao Japão. Não vamos apenas "pelo dinheiro", e "dekassegui”" tem conotações pejorativas, sugerindo, justamente, aquele cuja única motivação é a monetária. Nós, aqui “japoneses” e lá "brasileiros”, muitas vezes somos motivados pelo desejo de conhecer de perto a cultura de que somos herdeiros, e demonstrar isso foi motivo para aproximação: expressar-se na língua de nossos avós, demonstrando esforço, era sempre muito bem visto.

Nada disso, na fábrica. Nada desse encontro naquele espaço. Seu cotidiano era um só: o das máquinas, objetos cujos registros humanos, sua mensagem, eram difíceis de ler e, quando lidos, eram pobres e hostis ao próprio homem que os criou.

Mas disse que havia um objeto sagrado. Em todo aquele espaço, uma lata foi lugar de aconchego, de estabilidade, de onde podia seguir ao menos um pouco reconciliado comigo mesmo: uma pequena lata de biscoitos, cheia dos desenhos que normalmente as decoram, retangular, com a tampa lacrada ao corpo da caixa, e uma abertura da largura de uma moeda em seu topo. Nesse "cofrinho" púnhamos as pontas de estilete que se quebravam ou se desgastavam no corte do papel que limpávamos das bobinas usadas.

Essa caixa era fruto de minha atenção. Não me cansava de olhá-la, e isso me fazia um bem tremendo. Do pior trabalho, do que me machucava costas, mãos, eu ia feliz colocar minhas pontas quebradas de estilete. Gostava de ir até ela. Era um objeto com aura. Seu peso, considerável porque cheio de pontas de estilete, me punha em silêncio. Era como se aquilo guardasse a sabedoria de mestres artesãos. Como se dali aquelas lâminas fossem ser aproveitadas em algo muito especial, a caixa sendo transportada com 
reverência para seu destino final, para o que lhe dava sentido. Artesanato era sua origem e beleza seu fim. História de pessoas, vidas, estavam pacientemente sendo depositadas ali, como testemunho da bravura dos que também trabalharam. Numa parte considerável do peso daquela caixa mágica estava o trabalho do Kenzo-san. Na caixa mágica que - às vezes me pegava sonhando acordado, em casa - era o que eu iria salvar se acontecesse alguma coisa na fábrica e, de repente ela desmoronasse ou coisa parecida. Naquela caixa mágica, que escapava e resistia ao circuito reificante, colocada numa prateleira alta perto da única janela de vidro fosco, guardada no alto feito um lugar para onde se olha quando se reza.

\section{Ambientes}

Muito diferente andar pelas ruas à noite aqui e lá. $\mathrm{O}$ cenário pode até ser muito semelhante, com os mesmos carros circulando para um destino que não sabemos qual é, as mesmas poucas (lá, pouquíssimas) pessoas andando como você, prédios e casas com janelas iluminadas, as lojas fechadas, os estacionamentos vazios. Mas, nessas caminhadas, é como se a diferença estivesse toda naquele que anda.

Não existem padarias ou bares de esquina, ou lugares de encontro para as pessoas cuja fachada seja aberta e visível. Tudo é muito recolhido, discreto, não se mostra, nada é familiar, nenhum lugar existe para ir, simplesmente, ver pessoas. Onde estão as moças bonitas? Os jovens amigos que se reúnem para rir e conversar? As pessoas de todos os tipos circulando sem pressa para olhar o mundo, para se reconhecerem? Para onde vou, na esperança de, entre esses, encontrar amigos? Todos os lugares acabam tristemente iguais, no Japão. Sem sentido. Será por isso que há tantas casas de solitários jogos caçaníquel - os pachinko - onde muitos, brasileiros e japoneses, perdem seu dinheiro?

Lembro que foi uma revelação, uma alegria imensa para mim ter conhecido Nagoya: era a primeira cidade grande que conhecia, linda e movimentada. Meu lugar preferido acabou sendo a praça central, enorme, para onde todos iam no fim do dia, para virar a noite cheia de promessas. Muita gente andando, a maioria jovens, sentada nos bancos ou em volta das fontes. Alguns montavam seus equipamentos de som, com micro geradores de energia elétrica e toda tecnologia pela qual o Japão ficou conhecido, e 
apresentavam seu rock'n'roll oriental cheio da mesma energia bruta e vital que ouvimos aqui. Outros faziam cenas teatrais, danças, ou apenas assistiam, divertindo-se, conhecendo-se, namorando, vivendo. Lindo, lindo. Ali senti alegria nas pessoas, vi sorrisos, sempre com aquela encantadora maneira educada de ser. Tudo o que eu queria era fazer parte daquilo tudo. Nesse dia, quando conheci Nagoya, e depois, em Tokyo, gostei de estar no Japão, a primeira vez em que podia dizer que também amava aquele país. Desses lugares vou sempre sentir saudades.

Se tivesse aprendido a falar japonês, acho que não teria voltado. Teria vivido tudo aquilo, aboliria distâncias com os japoneses, mudaria meus cenários, teria aprendido tudo o que pudesse, iria até o fim, namoraria, arrumaria um trabalho melhor e estaria, certamente, feliz. Não tinha necessidade de metade das coisas que eles perseguiam sem se perguntar o porquê (carros, roupas, aparelhos eletrônicos, restaurantes e lugares da moda, esses infinitos objetos que são signos de riqueza), coisas cobiçadas apenas porque nasceram num país rico, e para mim isso era uma enorme vantagem: podia me concentrar nas experiências e pessoas que representavam algo mais autêntico daquele mundo.

\section{Chegar em casa}

Chegar em casa depois do trabalho era como ter vencido a mais dura prova física: o corpo ainda tenso, viril, ritmado, que reencontrava a pausa, o prazer de ter atingido seu objetivo, beirando seu limite. Mas a alma, essa era a de um bicho, um animal que durante todo dia reagiu aos ataques de um predador, para não morrer. Porque muitas vezes era com raiva que chegava em casa: raiva daquelas pessoas que não me entendiam, daquela máquina que me mordia os dedos. Tirava os sapatos ainda no passo rápido, em geral correndo, com que chegava, e me sentava, geralmente deitava, no chão. Entre esses atos, ligava meu aparelho de som com o rock'n'roll mais bruto e no volume mais alto que pudesse.

Mas depois de um tempo, quando o corpo se acalmava, a dor aparecia. Eu me levantava, encostado na parede e na pequena mesa no canto da sala, desligava o som e tentava, puxando para perto de mim um bloco de notas, escrever o que é que doía. Mas nunca consegui. Nunca tive coragem. Nessa hora, uma exaustão sem fim se instalava em 
meu corpo, uma tristeza sem fim na alma, e só o que saía eram poucas palavras de autoincentivo, tentativas de consolar-me. Não consegui, durante muito tempo depois de tudo ter acabado, aqui no Brasil, ler "Experiência da vida de fábrica", da Simone Weil - um texto pode doer mais que tudo no mundo. Hoje leio, porque o tempo passou. Mas essas palavras que uso para descrever lembranças são sempre um tanto falsas, levianas. Sintome traindo, desrespeitando tudo o que vivi, e o que vivem os brasileiros lá. O trabalho que fazia nos fecha, nos brutaliza, acaba com muita amizade possível que podemos oferecer a alguém, ou receber. Se não tivesse voltado, e não fizesse o que faço hoje, e não tivesse a companhia das pessoas que amo, seria um cara triste, tristeza sem cura - aqui, posso ao menos tentar, aqui não sofro aquilo tudo. O que sei é que entre colegas, nós nunca conversávamos sobre nossos desgostos no trabalho. No máximo, jogávamos irrefletidamente a culpa de nosso sofrimento nas costas de algum chefe mais duro na convivência. "Experiência de vida na fábrica" nunca foi para mim consolo, ou algo com que eu pudesse ajudar alguém, enquanto estive lá, no meio daquele sofrimento. Ali acho que só queremos, mais que tudo no mundo, coisas que nos lembrem do que é bom na vida, por mais fútil que seja. Celebrar a vida era o mais importante, o mais urgente.

Quando acontecia alguma coisa feliz - por exemplo, brincar com o Yukio (filho pequeno de um colega de Nagoya), ou girar sua irmãzinha nos meus braços fingindo ambos valsar - aí tudo ficava bem, e quando chegava em casa na noite de domingo, acendia um cigarro na varanda e pensava na semana que iria começar: nessa hora, o sofrimento que eu sabia vir ficava longe, e eu até me orgulhava do que estava enfrentando ali, "na raça". "O preço da vida se paga é vivendo, e depois recordando fiel o que foi dor e contentamento", dizia o Darcy Ribeiro. Às vezes, no fim do dia, no lado de fora da fábrica, ainda esperando o sinal para ir para casa, eu me abaixava e olhava o céu vermelho do fim de tarde; e acariciava o chão; e me orgulhava do que estava fazendo, do fato de estar pisando o chão japonês, um sonho realizado; e pensava no Brasil.

No dia 06 de junho: "Não fui trabalhar. Preciso me sentir gente de novo. O trabalho não enobrece os homens. Transforma-os em cães. Envenena sua alma.”

O que dói, quando lembro, é que eu poderia, talvez, ter agido diferente em muitas, muitas situações. Tenho vergonha de coisas que não fiz e de atitudes que não tomei, que poderiam ter-me aproximado das pessoas. O trabalho não teria sido esse inferno - eles 
também trabalhavam, como eu. Mas não consegui.

\section{Rosto}

Uma vez, por muito pouco, não agredi um garoto japonês que trabalhou comigo na linha de montagem.

Eu já estava há alguns meses no Japão e o meu primeiro objetivo, traçado logo após a terrível experiência nas primeiras semanas, quando senti o gosto do medo total de estar naquele país sem ninguém com quem contar, já havia sido atingido: ter o dinheiro suficiente para voltar a hora que quisesse. Era junho, e eu havia sido mandado para a fábrica maior da empresa, para onde vinham as peças que eu confeccionava e onde ficava a linha de montagem, além de todos os outros funcionários, inclusive os brasileiros.

Fiz vários trabalhos, o ritmo era acelerado, tenso até, pois era o mês mais importante da produção da Sato Koki: o auge das vendas de aparelhos de ar condicionado pela Toshiba, nossa contratante.

Um desses trabalhos era uma mesa de solda onde trabalhavam quatro pessoas: o soldador, eu bem à sua frente, e mais duas pessoas ao meu lado. Na mesa de diâmetro aproximado de dois metros, os coadjuvantes do soldador (este sempre um japonês) dividiam assim as tarefas: o cara à minha direita encaixava peças em outras peças que eu já havia encaixado nos suportes embutidos na mesa - que serviam para deixar o conjunto montado na posição ideal para receber a solda - e trocava os carrinhos de peças vazios pelos cheios; eu, no meio, encaixava as peças principais, de encaixe mais difícil e que deveria ser rápido como o ritmo do soldador (eles sempre reclamavam quando alguém causava qualquer tipo de parada, ainda que mínima) e também, com os pés plantados no assoalho e de frente para a mesa, dava dois giros largos de cintura, para trás, ora para direita ora para a esquerda, descolava fitas adesivas das borrachas que tinha que colar em partes específicas da peça e retirava do carrinho as peças que todos usavam para montar o conjunto, deixando-as dispostas em ordem numa pequena bancada atrás de mim, para onde eu esticava a mão para pegar as peças e montar minha parte. Não havia um único segundo de pausa em meus movimentos, apenas quando o próprio soldador parava o giro da mesa para alcançar mais algumas varetas do estanho que derretia sobre as juntas que 
encaixávamos, ou quando o carrinho cheio de peças havia sido estacionado muito longe pelos caras da outra seção - mas mesmo isso não levava mais que alguns segundos.

Finalmente, a pessoa que trabalhava à minha esquerda era responsável por verificar se o conjunto estava bem finalizado, com encaixes e solda bem feitos, para daí acomodá-lo no carrinho que o levaria para o próximo - e desconhecido - passo no processo de produção. Este rapaz era um japonês jovem, adolescente de no máximo dezoito anos, filho de um dos soldadores antigos da fábrica.

Eu trabalhava bem, trabalhava rápido, e era por isso que tinha sido posto ali - e porque eles sempre nos mudavam de lugar - mas mesmo assim não estava bom para o rapaz: ele sempre me cutucava, batendo o indicador em meu ombro, para me mostrar alguma peça mal acabada que a seu ver estava assim por minha causa. Fazia isso como se estivesse pronto para me bater, cara fechada e nenhuma palavra. Aliás, negava-se a falar comigo, recusando sempre meu sorrisos, ou meus "bom dia" e "boa noite, até amanhã". Quando queria alguma coisa, era cutucada no ombro, cara fechada e dedo apontado para o que ele queria. Era freqüente também ele colocar as peças que retirava sobre meu material posto na bancada, o que me atrasava porque isso embaraçava as peças que eu pegava para encaixar na mesa de solda. Pedi, mais de uma vez, para que ele não fizesse aquilo, "onegaeshimasu" ("por gentileza”), porque não era preciso - havia outros espaços para ele estacionar suas peças quando estivesse apurado - e porque, como disse, isso acabava atrapalhando a todos, já que eu é que alimentava a linha. Ele agia como se fosse humilhante para ele estar ao meu lado ou ter que falar comigo; ele tinha desprezo por mim e nunca escondeu isso. Eu apenas não entendia por quê.

Era tristeza o que experimentava todo dia, o dia todo, ao lado daquele garoto. Sempre fazia comentários agressivos, a meu respeito ou do meu parceiro ( o Juninho), quando fazíamos a mesa parar e o soldador levantava os olhos e mais ainda a voz na nossa direção. A única coisa que me alegrava era tentar fazer meu trabalho cada vez mais rápido e meus giros da maneira mais ergonômica para preservar meu corpo - isto como um treinamento de uma habilidade física, o outro como uma competição com os "japas", como que para dizer-lhes: "andem logo que aqui tem um mais homem que vocês", um cara que trabalhava mais e melhor. Desafio que eles sempre ignoraram - por não perceberem, por não se sentirem realmente intimidados, por acharem ridículo. 
Um dia, o rapaz jogou duas peças que havia tirado da mesa porque não estava acompanhando o ritmo do nosso trabalho, e as jogou em cima das minhas peças. Pegueias, abri um espaço vazio no canto próximo dele e as pus lá. Eles pegou-as e as jogou de volta, de propósito, de novo sobre as minhas, e ficou me olhando raivoso, como quem diz "aqui quem manda sou eu".

Eu queria matá-lo. E tenho certeza que era o que eu faria, porque era muitíssimo mais forte que ele, estava furioso, ele seria pego de surpresa e, ali onde estávamos, daria tempo de machucá-lo gravemente antes de alguém conseguir me segurar, até eu voltar a pensar no que estava fazendo. Eu não tinha mais nada a perder, estava sendo humilhado e morto por dentro porque sentia-me só naquele inferno de gente que me odiava, e tinha dinheiro para ir para casa. Pensei até que ser expulso do país seria ótimo para mim: seria o melhor jeito de deixar para a história o registro de meus sentimentos para com o país até então.

Meu corpo ficou tenso. Parei meus movimentos e voltei-me, ficando de frente para ele. Ele percebeu o que iria acontecer, arregalou os olhos e teve medo, tenho certeza. A mesa parou de girar, os outros entenderam o que iria acontecer, não se atreveram a pôrse entre nós. Minhas mãos já estavam fechadas, os joelhos levemente flexionados, pés plantados no chão, prontíssimo para o ataque. Eu era pura fúria cega, não me importava nem comigo mesmo, se morresse se vivesse, não tinha a menor importância. Eu era uma coisa que mata, que mata fria e sem consciência. Quem descobre que isso pode existir dentro de si nunca esquece, passa a ter medo de si. Um dia, ainda lá, assisti "Clube da Luta", e li no jornal brasileiro o caso do rapaz que metralhou pessoas num shopping... Saí na rua uma noite com um só objetivo: arrumar uma briga: encarei gente, dei esbarrões e "ombradas", e depois da terceira ou quarta tentativa voltei para casa e chorei muito, porque estava enlouquecendo.

Não bati no garoto. No intervalo entre minhas mãos cerradas e seu rosto algo me fez vê-lo, no fundo de seu ódio sem motivo por mim: um menino assustado, como qualquer homem naquele mundo, que me odiava sem saber o porquê, e que carregava em si esse ódio que, sei, não era dele. Seu ódio não era ele, não era dele. Era o ódio que aprendera de seu pai, que aprendera de seu avô, que aprendera dos primeiros homens que um dia sofreram na carne esse ódio aos homens, sem nome e sentido e que está inscrito 
em cada máquina daquela fábrica. Ódio que ele, menino, experimentou um dia voltado contra si.

Não era ele quem me agredia diariamente. Era algo através dele, que o machucava também.

Respirei, voltei-me de volta para a máquina, e continuei meu trabalho, absolutamente transtornado, a alma partida ao meio. Tremia. À noite, em casa, quando meu corpo e meu tempo eram meus de novo, chorei. Não sabia quem eu era, onde estava, o que foi aquilo que tinha vivido e que, até hoje, me interroga.

\section{Livros}

Aos domingos, meu dia de folga, acordava muitas vezes com um telefonema de minha mãe. Difícil dizer, para quem está distante, o que estamos vivendo, porque é difícil dizê-lo para nós mesmos.

Era dia de cuidar da casa, de cozinhar o feijão ou temperar a carne que iria comer durante a semana, de lavar o uniforme. Mas era, principalmente, o dia de simplesmente viver o dia, experimentá-lo: o transcorrer do tempo, as luzes de dia chuvoso ou ensolarado, a sensação da temperatura - os dias japoneses apenas, naqueles horários que eu nunca via durante a semana e que eram quase como se não existissem.

A sensação era sempre a de ter pouco tempo para aproveitar, mas lá ia eu, andar pela cidade. Para descer do meu bairro até o centro levava uns vinte minutos, meia hora. Meu destino - para poder ter um - era a loja de produtos brasileiros, mas o que esperava sempre era poder encontrar algo novo pelo caminho, aprender, ver as pessoas.

A maior parte do caminho todo era solitária. Poucas pessoas nas ruas. Daí olhava os detalhes das casas, as cerejeiras mudando lentamente de aspecto a cada passeio meu ao longo do ano, as escolas fechadas no dia mas abertas e cheias na minha imaginação, assim como os templos e praças e ruas comerciais. Olhava também os cemitérios e os arrozais que também sempre apareciam nas minhas caminhadas, mas evitava as grandes avenidas, estéreis e cheias de carros indo para lugares que eu nunca conheci, de grandes lojas, estacionamentos, sem nada residencial, sem jardins plantados por alguém que realmente se importasse com a vida de suas plantas. Preferia sempre as ruazinhas 
estreitas, onde a vida se recolhia nas casas; vida que eu nunca a via mas, pelo menos, sabia estar lá. Via dojos (locais de treino) de sumô e de arquearia, esta uma tradição da cidade, sonhava conhecer suas práticas de perto. Lindo, singelo, tudo o que via. Já lá no centro, a praça do templo, cheia de árvores altíssimas, antigas - e como tudo parecia antigo nas partes mais bonitas da cidade. Os grandes toori (portais xintoístas) nas entradas da praça, à frente e nas duas laterais, vermelhos, que purificam a alma daqueles que os atravessam. Lá longe, o Fuji-san.

Às vezes arriscava entrar em alguma lojas que estivesse aberta, só para ver alguém. Onde houvesse aglomeração de carros, eu ia. Em geral eram lojas de conveniência, onde as pessoas passavam rápido para comprar algo para comer. Ou uma loja de CDs e mangás (quadrinhos japoneses), onde de vez em quando comprava algo para ouvir em casa. Certa vez arrisquei entrar numa livraria, mas fui embora logo, quase correndo, pois fiquei triste naquele lugar que, mais que todos os outros, me dizia que eu não era dali. Os livros, de que gosto tanto...

\section{Homens e mulheres}

“As japonesas são lindas”, escrevi em 27 de março, "Graciosas, delicadas, e seu sorriso só aumenta o encanto". Uma vez, entrando na fábrica, notei que havia algumas moças andando logo atrás de mim. Fiz o que me parecia natural: abri a porta e lhes dei passagem. Mas aí elas pararam também, e ficaram me olhando, sem entender. Fiz o gesto com a mão, e disse sorrindo, caprichando na gentileza: "Onegae shimasu” (algo como "por gentileza"), e para reafirmar, tentei em inglês, "ladies first, of course". Ainda se recusaram um tempo, gesticulando timidamente que não, e um pouco incrédulas com

minha atitude de cortesia, entraram, agradecendo muitíssimo. Por essas e outras nós brasileiros éramos tidos por cavalheiros muito gentis com as mulheres. Engraçado.

\section{A máquina}

"Quanto a sofrer nesses lugares até transformá-los em espaços onde poderemos sentir-nos em casa"(29/03/2000). Aquele aço todo, chocando-se violento, aqueles 
gigantescos espaços que são as fábricas me faziam pensar em quanto tempo as idéias em que acredito ainda levariam para metamorfosear suas formas anti-humanas. Na Sato Koki, 03/04/2000: "O passado me deu segurança!". Escrevi isso lembrando-me dos tempos de escola técnica aqui no Brasil, segundo grau técnico em mecânica pela Escola Técnica Federal de São Paulo, onde me familiarizei com fresadoras, tornos, soldas, fornos de fundição, paquímetros e micrômetros, controles pneumáticos, etc. Embora tenha optado, ao final do curso, nos vestibulares, pela psicologia, tinha guardado o gosto por certas atividades nas oficinas: era bom ajustador e torneiro, médio marceneiro de modelos de fundição e excelente soldador, tanto na acetilênica quanto na elétrica (me lembro de economizar eletrodos nas aulas e depois recolher restos de material usado nas aulas com amigos para fazermos esculturas; lembro também de uma discussão que tive com o professor que não acreditou que eu havia feito o exercício com a peça na posição proposta, angulosa e difícil, porque o resultado do meu trabalho era bom demais para ter sido feito sem trapaça; precisei do testemunho de amigos e da repetição diante do mestre para honrar-me e, melhor, ganhar-lhe a amizade). Isso deve ter me ajudado, no dia, a ousar agilizar alguma operação em minha máquina: em quase todas em que me era possível rearranjava comandos, topes de retorno de serra, ou curso de brocas automáticas para tornar esses elementos mais rápidos e, com isso, ganhar mais tempo de descanso ou, conforme o caso, mais produtividade. O tipo de macete que operário nenhum conta ao patrão. (Num mundo socialista, eu seria psicólogo? Acho que não...)

\section{Silêncios}

Não escrever para o Brasil significa muitas coisas: não ser fácil lembrar-me das pessoas que foram boas comigo naquela experiência tão solitária, sem saber onde estão, como estão; lembrar-me das minhas faltas diante delas, do que não disse, do que não fiz; a sensação de que muito ficou incompleto, mal-entendido, mal acabado, apesar do amor que tenho pelo que vi lá; medo de como vão ser acolhidas estas lembranças, do que elas podem significar.

"Nenhuma poesia sobre o povo é autêntica se a fadiga não estiver presente nela, assim como a fome e a sede nascidas da fadiga." (Simone Weil) 
Tudo o que me lembro muitas vezes é da exaustão no fim do dia. Arrancar do fundo de si mesmo as últimas forças para fazer as últimas tarefas do dia, bater o cartão e andar a passos rápidos, que quando estamos fora da vista do patrão se transforma em corrida mesmo, pelas escadas até a porta de casa. Dentro, retirar os sapatos, abrir o botão da calça, tirar o boné da fábrica, e espalhar-se no chão da sala, num suspiro; respirando para, agora, voltar a habitar meu próprio corpo: doído, exausto, suplicante de repouso, que agora não consegue mais reagir, meu corpo gasto, feito coisa, judiado por aquela máquina má e indiferente. Durante todo meu dia não via, às vezes, o sol.

Meus vizinhos de casa e colegas de fábrica chegam também. A mesma urgência nos passos nos rapazes; um ritmo mais calmo nas moças, ditado igualmente pelo cansaço. Nos braços da mais nova, eu vi, as marcas das pequenas queimaduras feitas pelas peças ainda quentes de solda que ela manipulou o dia todo, guardando-as nos carrinhos. A proteção que sua família lhe dá contra a urgência da necessidade a faz sentir-se menos responsável, menos envolvida pelo trabalho. Mas igualmente, sem sua consciência, a vai desgastando também. Fica-lhe uma beleza triste. A determinação do restante da família, que voltou para casa com patrimônio passo a passo e duramente construído, talvez tenhalhe compensado alguma coisa - as marcas no bracinho jovem, a ausência da escola, a falta dos motivos de sua vida vivida lá, sua fadiga precocemente sentida, aos quatorze.(Fabiana).

O que mais me lembro? De que a amizade era pouca, para mim que sentia que precisava de muita. Que, no entanto, minha timidez (e a deles) muitas vezes atrapalhou contatos mais simpáticos e próximos. Muitas vezes sentia, da parte de uma senhora que trabalhava comigo uma consideração que não era freqüente nos outros, como quando ela me ajudou na limpeza das escadas para que eu não me atrasasse para o início do dia, ou quando sorria no fim do dia e me dizia coisas que eu não entendia, mas eram ditas com ar consolador, sorridente e amoroso. Nessas horas eu tinha vontade de ficar, de suportar o que passava para me aproximar das pessoas. Achava que era ali que seria feliz: um trabalho estável e mais humano assim que aprendesse a língua, uma renda digna, amigos (e namorada) também, uma herança cultural imensa a conhecer... Não voltaria ao Brasil infeliz, afinal. O Japão, nesses devaneios onde ia quando alguém me devolvia a humanidade, era pura esperança. 
As pessoas encontravam diversas maneiras de perder-se naquela vida solitária. Alguns gastavam seu dinheiro nos "sunacos" (que funcionavam, no fundo, como prostíbulos); outros, nos "pachinkos" (imensos prédios de máquinas caça-níqueis, numerosíssimos em todo Japão); e outros ainda, esquecendo de sua vida aqui no Brasil: iam vivendo, sem ambições mas também sem preocupações em relação ao mínimo para sobreviver - saídas no fim de semana para algum churrasco ou pescaria com os amigos, tevê e só. Suas famílias recebiam, no máximo, dinheiro e falsas promessas de retorno. Inúmeras anunciavam em jornais as fotos de parentes, em geral pais, desaparecidos no Japão.

\section{Mochizuki-san}

Era uma sexta-feira. O dia corria como os outros naquela semana, acabávamos de retornar do almoço e eu só pensava no fím de semana de dois dias que teria, já que no verão a produção caía: o que produzíamos no inverno é o que estava sendo vendido agora pela Toshiba, me explicaram, o que produzíamos no verão estaria nas lojas no inverno, daí as vendas eram menores.

Eu estava na mesa simples, encaixando monotonamente peças em "y" que tinham suas pontas puncionadas e alargadas para tornarem-se encaixe em alguma parte do conjunto montado de tubulações de ar condicionado. A simplicidade da tarefa, o fato de estar descansado por causa da parada do almoço e a perspectiva do sábado livre me deixou bem humorado e relaxado. $\mathrm{O}$ hábito de trabalhar naquela máquina me deixava um pouco mais livre para me distrair um pouco, divagando sobre algum assunto ou plano para o fim de semana ou olhando para as outras pessoas da seção, já que a máquina ficava no centro e todas as outras à sua volta. Só não conseguia ver a Mochizuki-san, pois ela ficava bem atrás de mim, sentada numa máquina com função de prensa e encaixe de pequenos anéis em peças pequenas em forma de tripé. De frente para o conjunto, ela tinha que encaixar as peças em suportes e apertá-las para que recebessem a forças bem equilibradas e por igual, senão se soltavam e acabavam esmagadas.

Eu continuava meu trabalho e, embora não a pudesse ver, ouvia com clareza os sons de seu trabalho, a máquina descendo, pressionando as peças, a mesa girando, as 
peças que a Mochizuki tirava caindo na lata com as outras trabalhadas, as que ainda não sendo retiradas da lata que alimentava o processo. Repetido, ritmado, sons de ar comprimido, metal dobrando-se, pressionado, batendo entre si. Bem menos agressivo ao ouvidos que outras máquinas.

A Mochizuki-san, além de trabalhar em algumas máquinas, especialmente naquela, cujas peças não precisavam ser produzidas em grandes quantidades, era a responsável pela administração daquele prédio da Sato Koki, separado do prédio principal onde estavam as linhas de montagem. Cuidava do cartões de ponto, do escritório, auxiliava nosso chefe, Suzuki-san, e quando não tinha trabalho em sua sessão, ia como todos os outros para as máquinas. Moça gentil, simpática, era das poucas que tentava conversar comigo, me ensinar algumas palavras do japonês, me incentivar.

Pois, naquele dia tudo seguia normalmente. Todos trabalhavam em seus lugares, eu encaixava e tirava minhas peças, entediado mas suportando bem. Ouvi então a máquina da Mochizuki-san parando, o banquinho onde ela estava sentada se afastando, as caixas e latas sendo postas no lugar, ela caminhando para falar com o Ichikawa-san, nosso jovem chefe de seção, e saindo do nosso andar. Tudo rotineiro, conforme o que sempre acontecia: seu trabalho ali sempre era pouco, dificilmente ela passava tardes ali, como nós, de frente para a máquina. Discretamente terminou seu trabalho, desligou e arrumou tudo, levou o material para o Ichikawa, como sempre fez. Os sons acompanhavam com precisão o filme que se projetava em minha imaginação, pois estava de costas para a cena.

Dez minutos depois, terminei meu trabalho ali onde estava, desliguei tudo e voltei para minha máquina para seguir minha produção normal. Neste instante vi que o Suzukisan estava conosco e o Ichikawa-san estava pedindo para todos pararem seu trabalho para termos uma conversa. Me chamou, fui. Vi então que todos estavam lá conosco, pois o pessoal do térreo também havia subido. Em roda, o Suzuki-san falou e falou, uns dez minutos, fez alguns gestos com as mãos, apontou algumas vezes para a máquina da Mochizuki. Não entendi o que era aquela conversa, imaginei até que iríamos embora mais cedo. No fim todos voltaram ao trabalho, mas ele ainda pediu que a Aline me explicasse o que havia dito.

Soube então que a Mochizuki havia se acidentado, tentando salvar uma peça que 
havia entrado mal encaixada e que iria ser "matada" pela máquina. Ao tentar ajeitar rapidamente a peça, teve seus dedos polegar e indicador direitos esmagados. Havia sido levada ao hospital pelo Sano-san e não se sabia ainda se estava bem nem qual a gravidade do ferimento. Suzuki-san falou longamente sobre o cuidado e atenção que deveríamos ter, que não devíamos nos importar com as peças que a gente "matava", que nossa saúde era o mais importante e que não deveríamos ter pressa em nosso trabalho.

Voltei para meu canto. Levei algum tempo para ligar minha máquina e reiniciei meu trabalho transtornado, abismado. Muita coisa havia acontecido ali. Como não percebi nada? Como ela passou por aquilo e não tinha dado um grito, um sinal, feito qualquer coisa para que notássemos seu acidente? Mochizuki-san teve os dedos esmagados e ainda assim fez tudo para não paralisar a rotina de trabalho. Eu não acreditava, não entendia, não aceitava, achava tudo aquilo cruel.

No fim do dia fomos avisados que ela estava bem, que não havia quebrado nenhum dedo, que o ferimento não era grave e que ela voltaria ao trabalho após o final de semana, como todos nós.

Na segunda-feira, fui bater meu cartão, ela estava lá, com os dedos enfaixados mas ocupada com seus afazeres de sempre no escritório. Perguntei-lhe se estava bem, ela disse que sim, agradeceu sorrindo. O dia começou normal para todos. Ou quase.

O sinal das oito horas tocou, ligamos todos nossas máquinas, começara o dia. Pouco depois, notei que a Mochizuki-san estava conversando com o Fukasawa-san, da máquina de solda; logo depois, com a pessoa da máquina seguinte. Não me espantei, já que eventualmente ela fazia isso, para dar algum recado. Mas depois percebi que ela estava indo conversar com cada um de nós lá do setor, até que veio falar comigo. "Watanabe-san, chotto mate kudasai" (“espere um pouco por favor"), e me pediu para desligar a máquina. Então, tentando me fazer entender por palavras (“Gomen nasai”: "Me desculpe") e gestos (apontava os dedos), me pediu desculpas por ter se acidentado na sexta-feira. Disse outras coisas que não entendi bem, mas que reforçavam o pedido, e foi embora, enquanto eu tentava dizer sem conseguir que ela não precisava falar aquilo, que não fazia sentido. Mas nossa conversa terminou ali. Precisei voltar ao trabalho. Uma caixa enorme da peça 602 tinha que ser usinada ainda naquela manhã. 
A ida pro Japão também contribuiu pra afastar mais ainda o Japão de mim, pra colocar o Japão próximo e distante. Isso vai esclarecer mais ainda as condições do enraizamento: não basta ir pro Japão - como dekassegui, então, é tudo que não é recomendável. Entrar no país como uma pessoa enjeitada, a quem foi reservada a parte pobre ou bestial do trabalho, a quem foi reservada uma recepção de estranhamento exagerado, em que o fato de ser um filho de japonês não basta: é preciso ser japonês, falar japonês, etc, etc, etc.... Agora vem com muita força: sou filho de japonês, sou percebido como japonês e essa condição de filiação e essa percepção não pegavam! Eu não senti o correspondente disso em mim e dentro de mim e isso provoca uma situação tremenda. Fui buscar no Japão aquilo que as pessoas viam e que eu não tinha um correspondente certo, garantido. E esse sentimento não veio, senão precariamente, me momentos que, em geral, escapavam do circuito do trabalho: na experiência do sagrado diante do Fuji, no encontro com Kenzo-san, na caixa mágica. 


\section{CONSIDERAÇÕES FINAIS}

Por meio do trabalho da memória proposto nesta pesquisa, podemos dizer então que a condição dekassegui parece comportar motivações outras que não aquelas reconhecidamente econômicas. Motivações densas, múltiplas, de ordem simbólica, que parecem aspirar, aqui, a uma reconstrução de laços rompidos de participação em uma história: laços biográficos paternos inicialmente, que se abrem à reconstrução de laços com a ancestralidade e com as questões ligadas à história de comunidades de imigrantes japoneses e de migrantes brasileiros. Aspiração por um senso de identidade e orientação cultural a respeito de si, de participação em determinado conjuto de tradições assumidas conscientemente como próprias e de uma (ou mais de uma) comunidade de que se faz parte. Lugares simbólicos que para serem encontrados dependem da oferta dos outros, de memórias que se tornam bens culturais, com as muitas qualidades do encontro pessoal com o mundo humano, transformador e origem dos sentidos de si.

A condição dekassegui pode ser assumida, assim, como possibilidade de realização dessas aspirações. Porém, o que parece haver é um profundo desencontro entre o bem simbólico buscado e a situação econômica reificada, isto é, abstraída dos valores humanos contidos no trabalho. A imigração é determinada por condições ligadas ao trabalho desqualificado, que se iniciam ainda no local de origem e permanecem no local de destino das populações que migram. Apesar das muitas transformações no mundo do trabalho, ainda permancem, ao menos naquilo que testemunhamos no Japão, condições de opressão experimentadas pelos trabalhadores que não são diferentes daquelas descritas no início do século passado, por exemplo, por Simone Weil. Não é na dignidade do agente, daquele que age e fala, interfere e dá sentido aos rumos de uma determinada comunidade, encontrando aí sua liberdade, que é recebido o imigrante/migrante, instalando-se, assim, vivências profundas de desenraizamento.

É só, portanto, através de uma firme resistência que consegue realizar suas aspirações. Em geral, como se viu, fora dos círculos do trabalho reificado. 
A metodologia proposta pareceu ser a mais adequada ao objeto que se procurou constituir. A narrativa vem com traços de modos de lembrar dos grupos de que se faz parte, mas pode assumir um ponto de vista pessoal e original sobre o passado, revelando possibilidades e contradições que muitas vezes submergem na fala coletiva. Assim, pode-se através dela dar novos sentidos ao presente e ao futuro.

A narrativa pede aquele que a acompanhe e ajude a recolher sem pressa, que ajude a apontar o enigmático e o significativo, que auxilie o narrador a manter-se aberto para o que lembra, apóie e sugira ao depoente formas (ainda que provisórias) para o que surge demasiado sem nome, desligado de circuito mais consciente de suas interpretações. Daí a necessiade do trabalho que se fez com a dupla narrador/pesquisador e entrevistador/orientador. Este modelo permitiu a apropriação por parte do pesquisador dos elementos submersos às suas questões iniciais, fez surgir de seu trabalho narrativo um senso novo de enraizamento em determinados tempos e espaços, fundou possibilidades de reflexão, de reencontro com questões presentes na subjetividade dos dekasseguis que transcendem o biográfico e só encontram no político e na convivência humana a possibilidade de superação do sofrimento de não poder permanecer onde queremos e não poder pertencer a lugar nenhum.

Esta pesquisa, ainda em curso, se encaminhará para um trabalho maior e complementar, que pretenderá então assumir como tarefa a validação e enriquecimento das atuais hipóteses aqui apresentadas, encontrando eventualmente outras, agora num trabalho com narrativas de outros depoentes dekasseguis. 


\section{REFERÊNCIAS BIBLIOGRÁFICAS}

ASCH, S. Psicologia Social. S. Paulo: Cia. Editora Nacional, 1977.

BOSI, E. O tempo vivo da memória: ensaios de Psicologia Social. S. Paulo: Ateliê Editorial, 2003.

GEERTZ, C. A interpretação das culturas. Rio de Janeiro: LTC, 1989.

GONÇALVES FILHO, J. M. Humilhação: um problema político em Psicologia. Psicologia USP, S. Paulo, v. 9, n. 2, pp. 11- 66, 1998. Problemas de método em Psicologia Social: observação participante e entrevista com roteiro. Texto ainda não publicado disponível no Departamento de Psicologia Social e do Trabalho da Universidade de São Paulo.

JAKOBSON, R. Lingüistica e comunicação. S. Paulo: Edusp, 1969.

JOÃO ANTÔNIO. Malgueta, Perus e Bacanaço. São Paulo: Clube do Livro, 1987.

KAWAMURA, L. Para onde vão os brasileiros? Imigrantes brasileiros no Japão. Campinas, SP: Editora da UNICAMP, 1999.

LEMINSKI, P. Basho. A lágrima do peixe. São Paulo: Brasiliense, 1983.

SAFRA, G. A poética na clínica contemporânea. São Paulo: Aparecida, SP: Idéias \& Letras, 2004. . A hermenêutica na situação clínica. São Paulo: Sobornost, 2006.

SAKURAI, C. Romanceiro da Imigração Japonesa. São Paulo: Editora Sumaré: FAPESP, 1993.

WEIL, S. A condição operária e outros estudos sobre a opressão. Seleção e apresentação Ecléa Bosi. S. Paulo: Paz \& Terra, 1996.

O enraizamento. Bauru, SP: EDUSC, 2001. 
ANEXOS 


\section{Roteiro para a reconstrução autobiográfica (quadros)}

O percurso de uma identidade nipo-descendente e as transições até a experiência dekassegui.

\section{Em família}

Quadro 1

\begin{tabular}{|c|c|}
\hline $\begin{array}{l}\text { Marcos derivativos e o que } \\
\text { desejamos investigar }\end{array}$ & Questões \\
\hline $\begin{array}{l}\text { O pai issei / nissei. } \\
\text { A relação do pai com a raiz } \\
\text { japonesa dele mesmo e do filho. }\end{array}$ & $\begin{array}{l}\text { Você conviveu com seu pai, na casa materna, } \\
\text { até os três anos de idade, quando então seus pais } \\
\text { se separaram. } \\
\text { Suas lembranças dele são deste período e do } \\
\text { período que se seguiu (até a morte de seu pai)? } \\
\text { Que você recorda do contato com ele nesses } \\
\text { dois períodos? } \\
\text { Ele agia como um pai japonês? Falava do } \\
\text { Japão? Seu pai assinalava sua condição } \\
\text { japonesa, abordava você como filho de um } \\
\text { japonês? Vocês eram fisicamente parecidos? } \\
\text { Você lembra de episódios a respeito disto tudo? }\end{array}$ \\
\hline $\begin{array}{l}\text { A mãe. } \\
\text { A relação da mãe com a raiz } \\
\text { japonesa do filho. Os mimos da } \\
\text { mãe. A mãe e as evocações do } \\
\text { marido. }\end{array}$ & $\begin{array}{l}\text { Sua mãe pai assinalava sua condição japonesa, } \\
\text { abordava você como filho de um japonês? } \\
\text { Vocês são fisicamente parecidos? Você lembra } \\
\text { de episódios a este respeito? }\end{array}$ \\
\hline $\begin{array}{l}\text { As tradições pernambucana e } \\
\text { japonesa. } \\
\text { Hábitos e costumes na família. } \\
\text { Eventuais conflitos culturais. }\end{array}$ & $\begin{array}{l}\text { A tradição japonesa e a tradição pernambucana } \\
\text { eram marcantes em sua família? Quais marcas } \\
\text { das duas culturas eram parte de seu cotidiano? } \\
\text { Havia hábitos ou costumes característicos prati- } \\
\text { cados na alimentação, no vestuário, nos estudos, } \\
\text { normas de comportamento, obrigações com } \\
\text { parentes? Que você lembra? }\end{array}$ \\
\hline
\end{tabular}




\begin{tabular}{|c|c|}
\hline $\begin{array}{l}\text { Os irmãos. } \\
\text { Os irmãos e a nipo-descendente } \\
\text { do caçula. }\end{array}$ & $\begin{array}{l}\text { Fale um pouco de seus irmãos. } \\
\text { Os irmãos assinalavam sua condição nikkey? } \\
\text { Você se lembra como? Há episódios de que } \\
\text { você se recorda? Você me disse haver um irmão } \\
\text { seu praticante de kung-fu. }\end{array}$ \\
\hline $\begin{array}{l}\text { Os parentes. } \\
\text { Os parentes e a condição } \\
\text { nipo-descendente do depoente. }\end{array}$ & $\begin{array}{l}\text { Viagem para Caruaru (Pernambuco) e o } \\
\text { encontro com duas pessoas: a vizinha de uma } \\
\text { prima de minha mãe (prima de Caruaru) e o } \\
\text { jovem amigo da mesma prima. Uma visita, } \\
\text { apresentação a uma tia materna (velhinha, bem } \\
\text { gorda e grisalha) espantada com o } \\
\text { "japonesinho". Outra visita, apresentação a uma } \\
\text { prima (jovem como então a mãe, e que vivia } \\
\text { demandando favores da mãe). }\end{array}$ \\
\hline $\begin{array}{l}\text { Os } \quad \text { parentes } \\
\text { (pernam-bucanos). }\end{array}$ & $\begin{array}{l}\text { Na sondagem de marcos, você evocou estes } \\
\text { encontros como episódios marcantes na } \\
\text { formação da consciência de você como de um } \\
\text { menino nikkey. } \\
\text { Você se lembra o que tornou esses encontros } \\
\text { marcantes, como foram? Lembra outros } \\
\text { encontros marcantes com a família materna? }\end{array}$ \\
\hline $\begin{array}{l}\text { A reaparição dos parentes } \\
\text { japoneses. }\end{array}$ & $\begin{array}{l}\text { Tia Elza. O reencontro com o pai. Viagens para } \\
\text { Itanhaém com primos e Tia Elza, uma vez } \\
\text { acompanhado também pelo pai. } \\
\text { Ao evocar esses episódios, agora com parentes } \\
\text { paternos que reapareceram, você justamente } \\
\text { falou na "reaparição" deles, os parentes } \\
\text { japoneses! O que sugere que seus parentes isseis } \\
\text { e nisseis já contavam antes. Contavam? Como } \\
\text { contavam em sua vida, você se lembra? Como } \\
\text { foi esta retomada do convívio com a família } \\
\text { japonesa? } \\
\text { O que se lembra do reencontro com o pai? }\end{array}$ \\
\hline Outro parente japonês: tio & \\
\hline
\end{tabular}




$\mid$\begin{tabular}{l|l|}
$\begin{array}{l}\text { Chico, conhecido no casamento } \\
\text { do primo Edson, em Barra } \\
\text { Mansa (Rio). }\end{array}$ & $\begin{array}{l}\text { Você disse evocar este episódio como aquele } \\
\text { que comporta algo diferente de todos os } \\
\text { anteriores. O quê? Que aconteceu? }\end{array}$ \\
$\begin{array}{l}\text { O falecimento do pai. } \\
\text { A morte do pai alterou a } \\
\text { comunicação do filho com as } \\
\text { raízes japonesas? }\end{array}$ & $\begin{array}{l}\text { Seu pai faleceu em que circunstância? } \\
\text { Que aconteceu? }\end{array}$ \\
\hline
\end{tabular}




\section{Na cidade}

Quadro 2

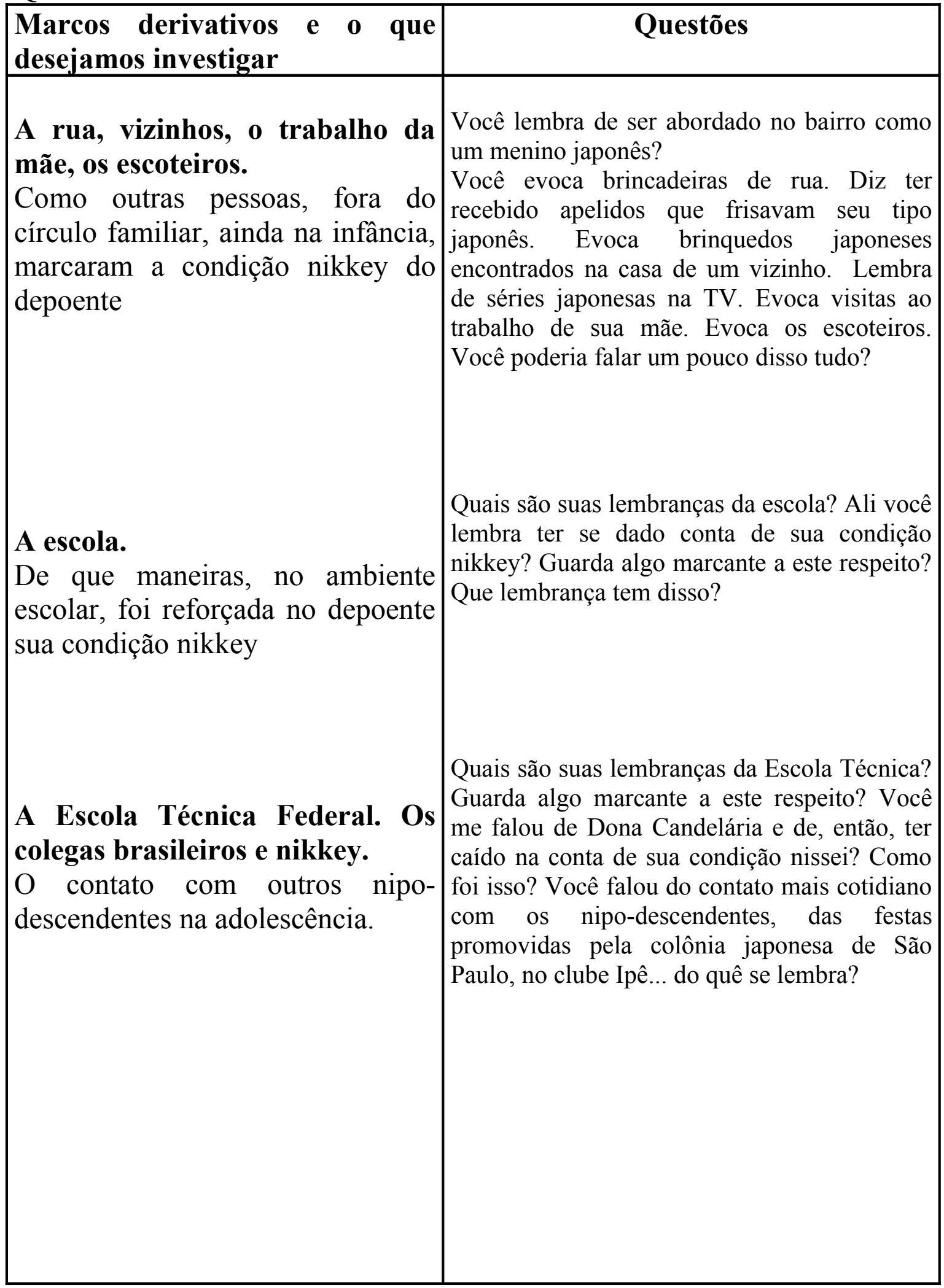




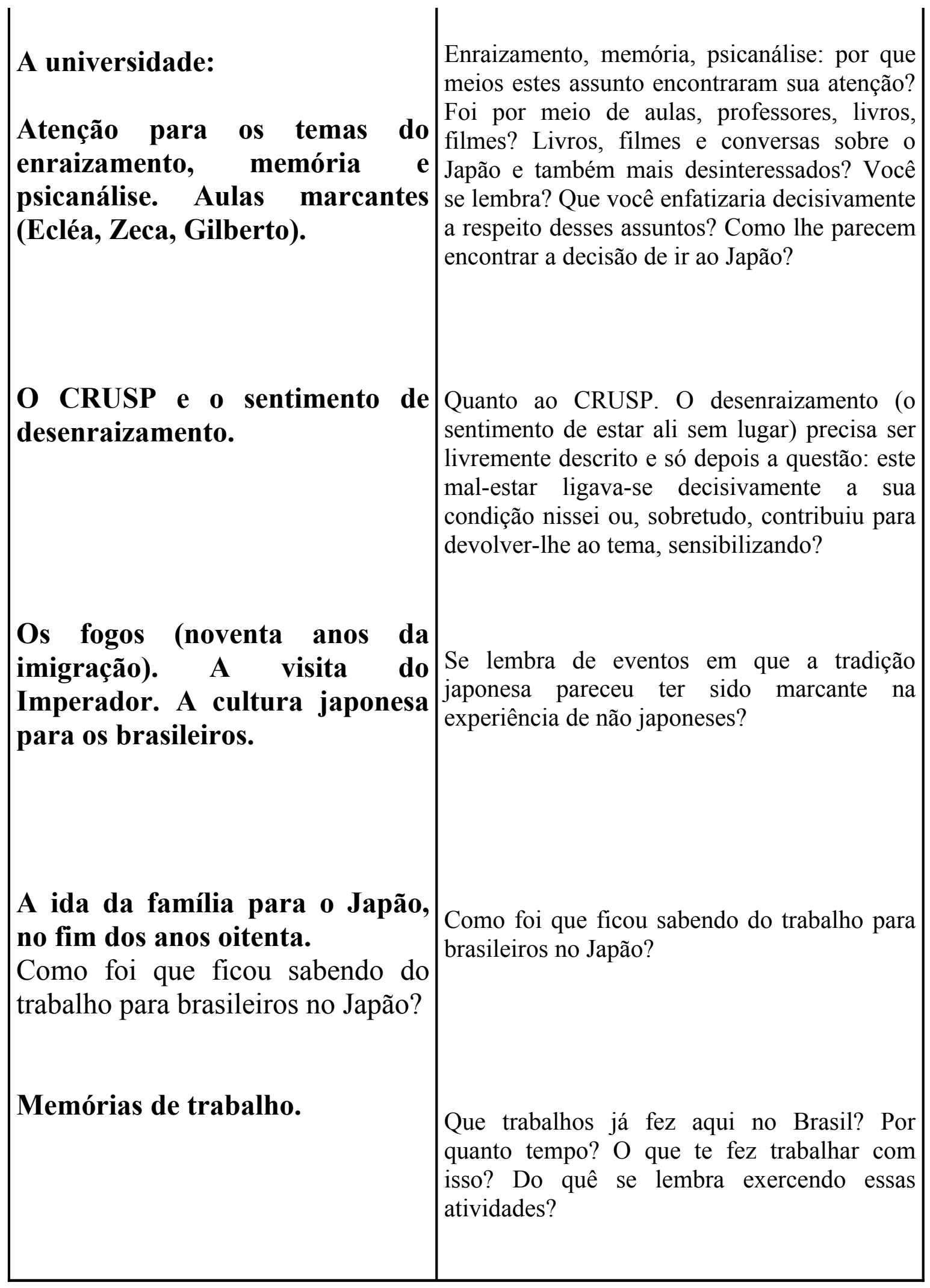




\section{A viagem ao Japão}

Quadro 3

\begin{tabular}{|c|c|}
\hline $\begin{array}{l}\text { Marcos derivativos } \\
\text { desejamos investigar }\end{array}$ e & Questões \\
\hline $\begin{array}{l}\text { No fim da graduação, a decisão de } \\
\text { viajar e uma conversa com a mãe. }\end{array}$ & $\begin{array}{l}\text { A decisão de viajar para o Japão foi tomada } \\
\text { no fim da graduação. Você se lembra? Você } \\
\text { disse lembrar do primeiro anúncio de sua } \\
\text { decisão de viajar para o Japão: foi uma } \\
\text { conversa com sua mãe. Você se lembra da } \\
\text { conversa? }\end{array}$ \\
\hline $\begin{array}{l}\text { Chegada a Tókio e primeiras } \\
\text { impressões. Encontro com Mari. A } \\
\text { viagem para Fuji. Uma noite e um } \\
\text { dia no alojamento. Dois brasileiros. }\end{array}$ & $\begin{array}{l}\text { Como foi sua chegada ao Japão? O que se } \\
\text { lembra dos primeiros lugares e pessoas que } \\
\text { conheceu? O que te diziam sobre a vida lá? }\end{array}$ \\
\hline $\begin{array}{l}\text { A viagem para Fujinomiya. A } \\
\text { prefeitura e primeiras providências. } \\
\text { Novo alojamento. }\end{array}$ & $\begin{array}{l}\text { Lembra-se de episódios sobre sua chegada } \\
\text { que ficaram na lembrança: o clima, a busca } \\
\text { pela documentação, a recepção dos colegas, a } \\
\text { nova casa, alguém que tenha te ajudado? } \\
\text { Como era sua casa? Quem eram seus } \\
\text { vizinhos, como vocês se relacionavam? }\end{array}$ \\
\hline Fujinomiya. & $\begin{array}{l}\text { Do que se lembra sobre a cidade em que } \\
\text { morou lá no Japão? }\end{array}$ \\
\hline $\begin{array}{l}\text { O reiterado estranhamento. } \\
\text { Correio, banco, dois } \\
\text { supermercados, uma loja de CDs, } \\
\text { uma livraria, duas grandes lojas de } \\
\text { roupas, ruas sem nome e a } \\
\text { dificuldade de ligar para o Brasil. }\end{array}$ & Como se saía nas tarefas cotidianas? \\
\hline
\end{tabular}


O caminho para o trabalho. $\mathrm{Na}$ fábrica de papel: as casas entre ruas estreitas; os arrozais; a cautela para não se perder; o rio com pescadores, a ponte de onde via o Fuji-san; as crianças indo à escola; a linha do trem, o trânsito, a entrada da fábrica.

O caminho para o trabalho. Na SK: do alojamento para a fabriqueta: chegada, saídas nas horas de intervalo, almoço com descanso em casa (leitura sobre o mundo e tevê com coisas do Japão), saídas apressadas (quase "fugas" pra casa). $\mathrm{O}$ estacionamento com os sakuras.

O caminho para o trabalho. Em Miahara: as saídas juntos ou os encontros com colegas no caminho; a falta de calçadas; a fábrica de instrumentos cirúrgicos (só com japoneses, a diferença nos respectivos funcionários das duas fábricas); o ponto de coleta de lixo; as ruas sem árvores, as lojas de mangás, os funcionários e suas diferentes chegadas(bicicleta, carro, a pé).

O caminho para as compras
Por onde circulava para ir ao trabalho? Como era andar por esses lugares? Pode descrevê-los, como eram? O que você via? Alguma coisas o surpreendeu, pelo estranho ou pelo encanto? 
consumo. Durante a semana: a Coop: as ruas vazias à noite, a fabriqueta mecânica, os prédios residenciais novos $\mathrm{e}$ as velhas casas, as cercas baixas.

O caminho para as compras e consumo. Aos finais de semana: loja de produtos brasileiros no centro, ou o outro supermercado também no centro: ocasiões de passeios, onde os cenários se confundiam.

O caminho de passeios: o centro, os templos, o Fuji onipresente, os centros de sumô e arquearia, os cemitérios e os pequenos templos, as casas e as pequenas ou grandes fábricas, máquinas de bebida e comida, os postos de gasolina e seus postos de gasolina, as ruas descalçadas, as ruas sem pedestres, as placas, as caixas de correio, as plantas e jardins, as pequenas plantações de arroz e chá, o rio (peixes e gente pescando), as ruas estreitas e o trânsito gentil, a pequena linha de trem. As crianças. Os velhos. A visão do Monte Fuji.

Feriados: livros, comidas, mercado, casa, caminhadas pela cidade; mercadorias brasileiras; games, carros, "pachinkos" e "sunacos"; Lago Hakone,
Por onde circulava para ir às compras? Como era andar por esses lugares? Pode descrevê-los, como eram? O que você via?
Por onde você circulava quando ia passear? Aonde ia? Quando ia? Como ia? O quê fazia? Tem alguma história de que se lembra? 
arquearia, sumô, yakiu; o professor de esgrima que não ensinava "gaijin"; os templos da cidade. "Enraizado no céu".

Primeiro dia de trabalho. Entrevista de trabalho.

O soko. Cláudio Ikematsu, Mori, Sassamoto. Os ombros doídos, as broncas, a antipatia de Mori, o aprendizado do trabalho, as broncas, o ressentimento.

Kenzo-san. A caixa mágica.

Rotina de trabalho; as máquinas.

Feriados: (ver "caminhos citadinos"): o Japão que desejava mas não vivia.

Como é que você conseguiu emprego?

Foi difícil aprender as suas tarefas de trabalho? Alguém ter ajudou?

Sofreu algum acidente de trabalho? Como aconteceu? Qual a reação das pessoas? Adoeceu lá alguma vez? Como se cuidou?

Tem boas lembranças de trabalho junto com os japoneses? Tem boas lembranças do próprio trabalho?

Ficou responsável pela operação de alguma máquina? Você fazia alguma coisa para modificar as rotinas de trabalho de modo a torná-las mais confortáveis, rápidas? Os japoneses (chefes ou não) gostavam de seu trabalho?

Que fazia nos feriados? Houve algum aprendizado ou atividade cultural japonesa em que se engajou? Conviveu com os japoneses fora do ambiente de fábrica? 
Pico de produção: transferência da SK para Miyahara

$\mathrm{O}$ refeitório, as "gentilezas" brasileiras. As procuras pelo "psicólogo". As falas sobre não poder confiar em brasileiros.

O garoto com quem quase briguei.

Os dedos esmagados de Mochizukisan.

As cartas dos amigos. Telefonemas. Os novos brasileiros. Futebol.
Dentro da mesma empresa, foi transferido de posto de trabalho? Qual? Por quê? O que fazia? Com quem trabalhou?

Que histórias lembra sobre a convivência entre brasileiros e japoneses na fábrica? $\mathrm{E}$ entre os brasileiros entre si?

Brigou ou viu alguém brigar com alguém dentro da fábrica? Do que se lembra a respeito?

Testemunhou algum acidente de trabalho com brasileiros ou japoneses? Do que se lembra a respeito?

Como eram suas relações como o Brasil quando estava lá? O que fazia? Como recebia notícias? Manteve contato? 